\title{
VALUATION APLICADO AO SETOR BANCÁRIO: Definição de um modelo de avaliação de bancos
}

\section{Emerson Tetsuo Miyazaki}




\title{
VALUATION APLICADO AO SETOR BANCÁRIO: Definição de um modelo de avaliação de bancos
}

\author{
Emerson Tetsuo Miyazaki
}

Professor Orientador:

Aldery Silveira Jr.

"Trabalho apresentado em cumprimento às exigências acadêmicas parciais da disciplina Estágio Supervisionado em administração para a obtenção do grau de Administrador" 
Miyazaki, Emerson T.

Valuation Aplicado ao Setor Bancário: Definição de um modelo de avaliação de bancos / Emerson Tetsuo Miyazaki. Brasília, 2009.

Monografia (Graduação) - Universidade de Brasília, Departamento de Administração, 2009.

Orientador: Aldery Silveira Jr., Me.

1. Finanças. 2. Valuation. 3. Bancos. I. Título. II. Título : uma revisão. 
Universidade de Brasília

Faculdade de Economia, Administração, Contabilidade e Ciências da Informação e Documentação

DEPARTAMENTO DE ADMINISTRAÇÃO

\section{VALUATION APLICADO AO SETOR BANCÁRIO: Definição de um modelo de avaliação de bancos} A Comissão Examinadora, abaixo identificada, aprova o Trabalho de
Conclusão do Curso de Administração da Universidade de Brasília do
aluno

\section{Emerson Tetsuo Miyazaki}

Aldery Silveira Jr., Mestre

Professor-Orientador

Domingos Sávio Spezia, Mestre

Professor-Examinador

Brasília, 17 de junho de 2009 
Aos maiores e melhores mentores que tenho na vida, meus pais. 
Ficam os agradecimentos a toda minha família e amigos por todo o apoio. A toda a equipe de Análise de Investimentos da FUNCEF e do Banco Fator pelo apoio e inúmeras contribuições na elaboração do presente trabalho. Agradeço também ao professor Aldery, por me orientar na elaboração do trabalho e a todo o corpo docente da Universidade de Brasília por todo o aprendizado transmitido ao longo dos anos. 


\section{RESUMO}

As finanças de empresas têm evoluído muito no que diz respeito à avaliação de empresas convencionais, dada a grande importância que se têm dado ao "valor" nas empresas, seja para aplicá-las em casos de fusões, aquisições, acompanhamento de performance dos gestores ou outros motivos. No que diz respeito à avaliação de bancos, as formas convencionais de avaliação de empresas não são aplicáveis e a literatura corrente tanto de finanças como de contabilidade não abordam as peculiaridades do setor. A necessidade de material científico e acadêmico que aborde a avaliação e compreensão de instituições bancárias é clara, porém não explorada. A pesquisa apresentada no trabalho busca dar ao menos os primeiros passos para adaptar a avaliação de empresas convencionais à avaliação de bancos. O estudo apresenta os principais métodos de avaliação de empresas, as peculiaridades dos bancos em relação a empresas convencionais, a identificação dos principais vetores de valor dos bancos comerciais e a proposta de um modelo de montagem de fluxo de caixa descontado para chegar ao valor intrínseco de bancos. Após a definição desse modelo, ele foi submetido a testes em dados passados do Banco Bradesco para verificar a sua aplicabilidade. 


\section{SUMÁRIO}

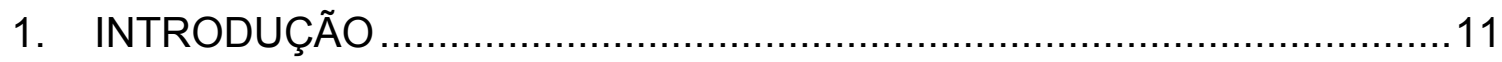

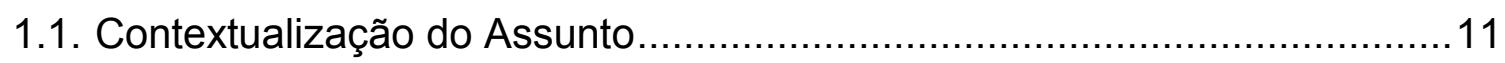

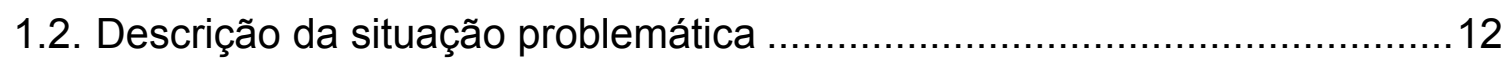

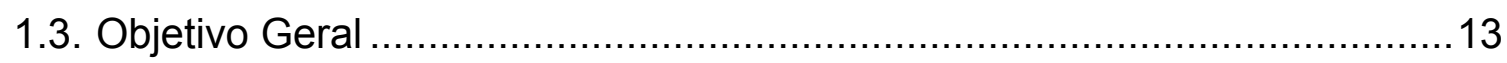

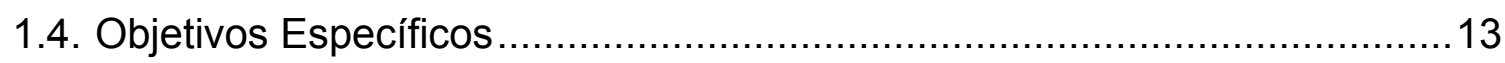

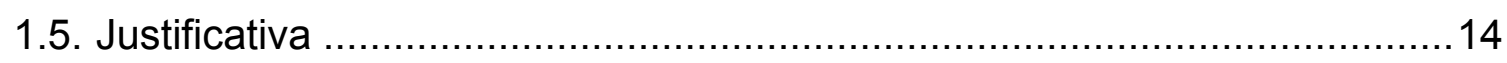

1.6. Metodologia (Métodos e Técnicas de Pesquisa): .......................................14

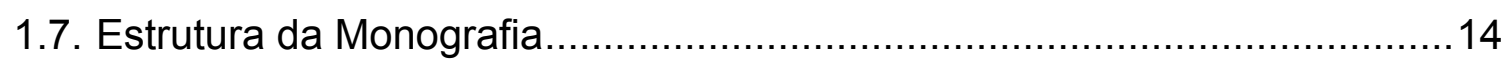

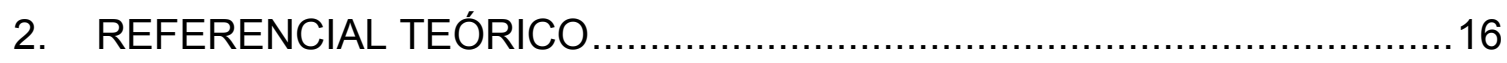

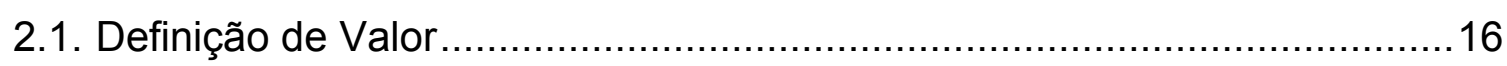

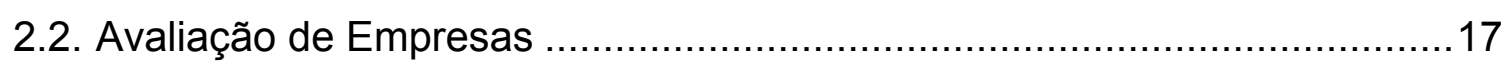

2.3. Métodos Tradicionais de Avaliação de Empresas .....................................18

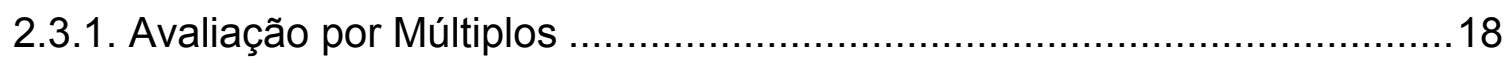

2.3.2. Avaliação por meio do Fluxo de Caixa Descontado ...............................19

2.3.3. Avaliação por meio de Opções Reais ...................................................19

2.3.4. Preferência pelo Fluxo de Caixa Descontado ………………..................19

2.4. O Método do Fluxo de Caixa Descontado …….......................................20

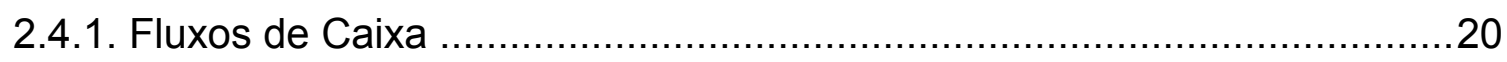

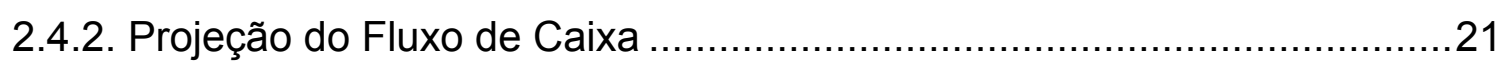

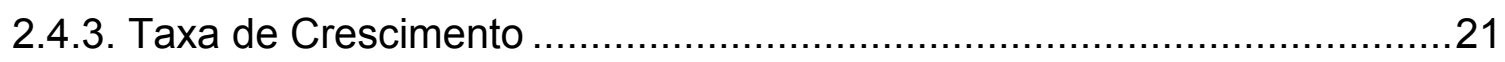

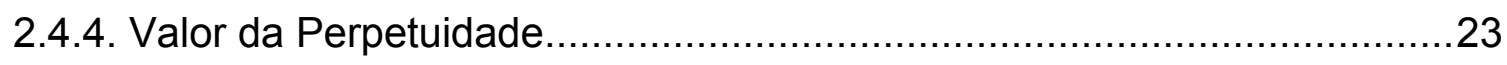

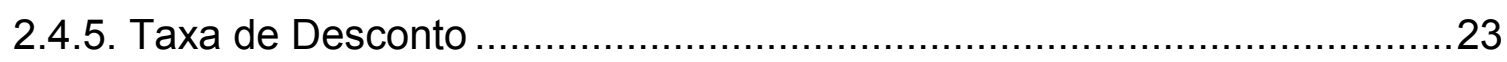

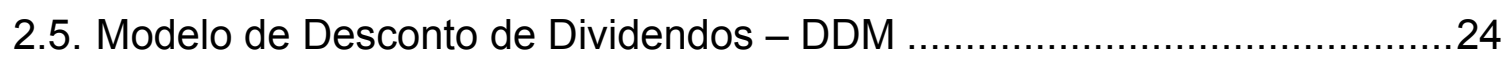

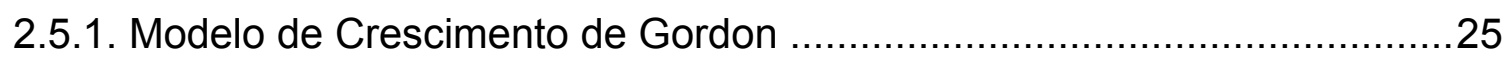

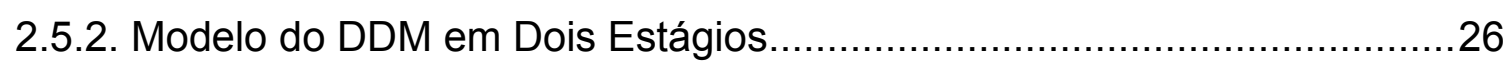

2.5.3. O Modelo H para Avaliação do Crescimento .........................................2

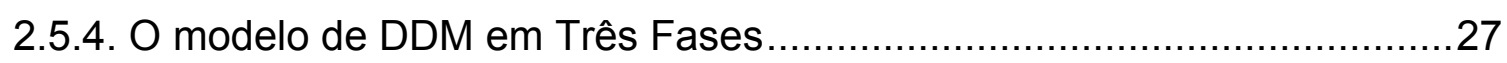

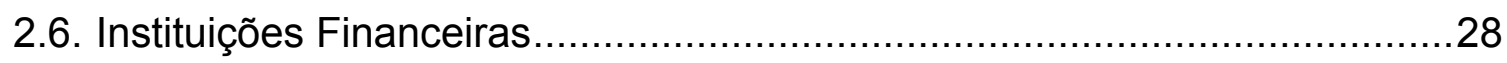

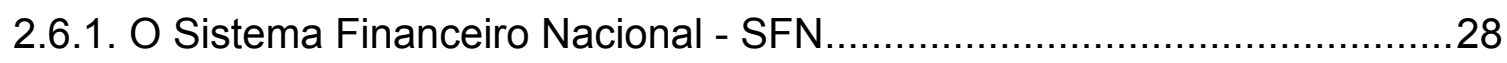

2.6.2. Plano Contábil das Instituições do Sistema Financeiro Nacional - Cosif.. 29

2.7. Demonstrações Financeiras de Bancos ...................................................29

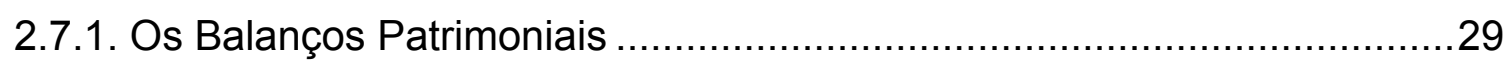

2.7.2. Demonstrações de Resultado do Exercício .............................................30

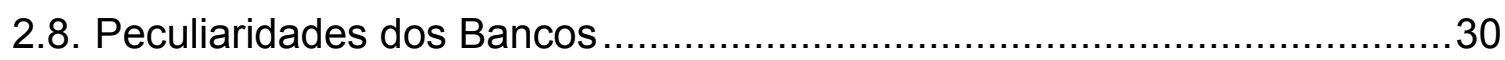




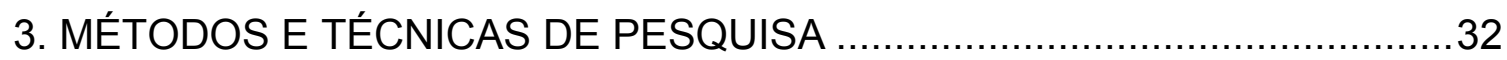

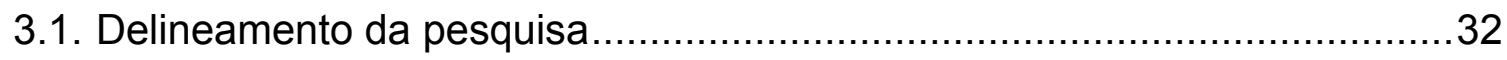

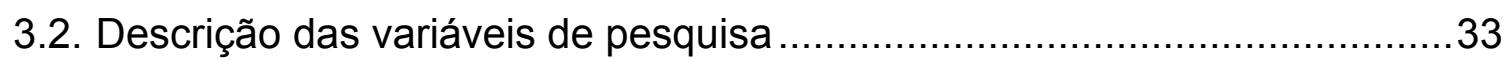

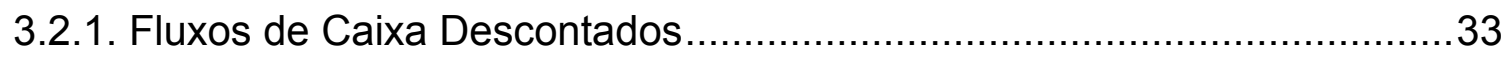

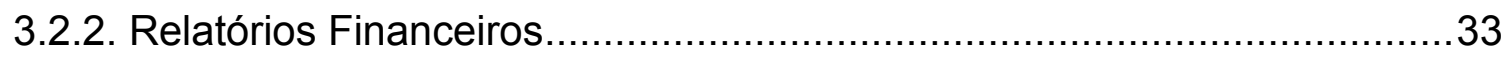

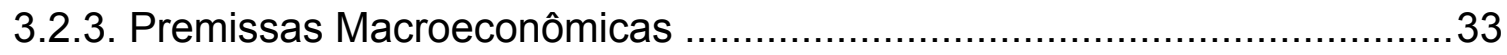

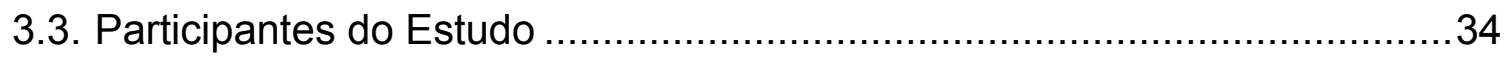

3.4. Procedimentos e instrumentos utilizados na coleta e análise dos dados....34

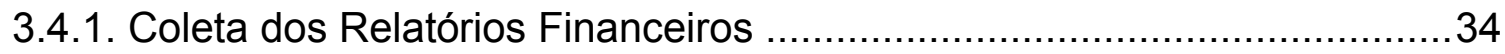

3.4.2. Coleta das Premissas Macroeconômicas ...............................................34

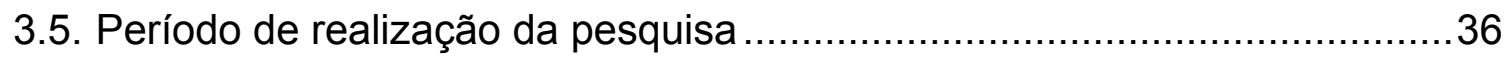

3.6. Comentários sobre o processo da coleta de dados ...................................36

4. APRESENTAÇÃO E ANÁLISE DOS RESULTADOS DA PESQUISA .........37

4.1. Agrupamento, ordenação e descrição dos dados coletados.......................37

4.1.1. Agrupamento dos Balanços Patrimoniais.............................................37

4.1.2. Agrupamento das Demonstrações de Resultado do Exercício .................38

4.1.3. Agrupamento das Premissas Macroeconômicas ....................................38

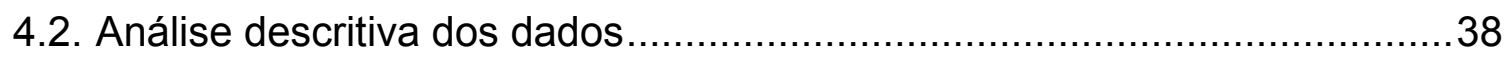

4.2.1. Seleção do Método de Fluxo de Caixa Descontado .................................38

4.2.2. Identificação dos Drivers dos Bancos ..................................................39

4.2.3. Projeção dos Balanços Patrimoniais ................................................... 40

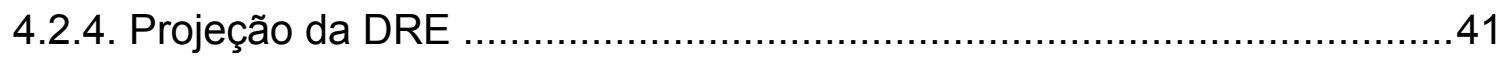

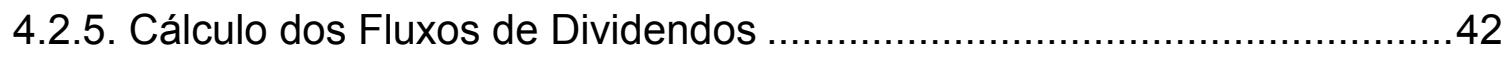

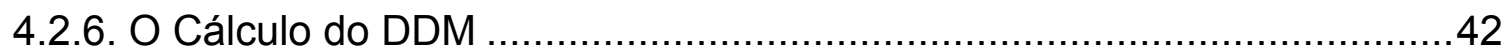

4.3. Consolidação do Modelo de Montagem de Fluxos de Caixa Descontados

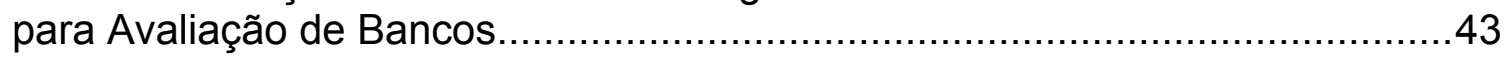

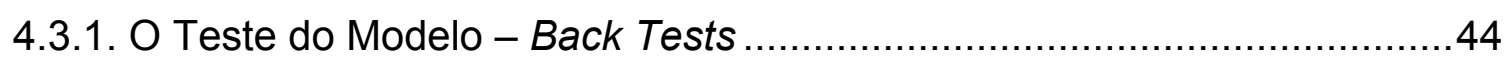

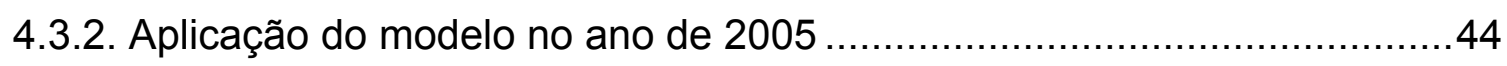

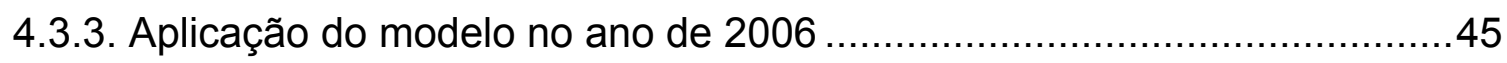

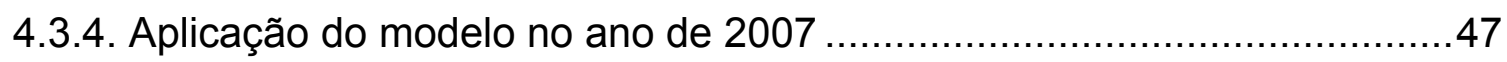

4.3.5. Comparação dos Valores Obtidos com as Cotações em Bolsa ................48

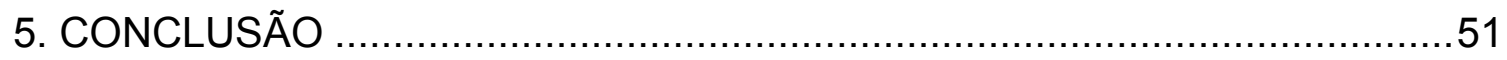

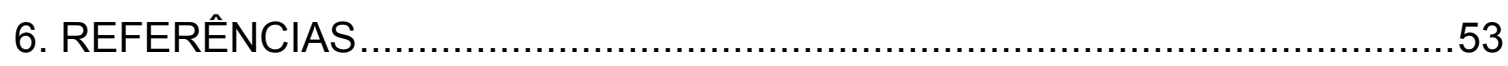

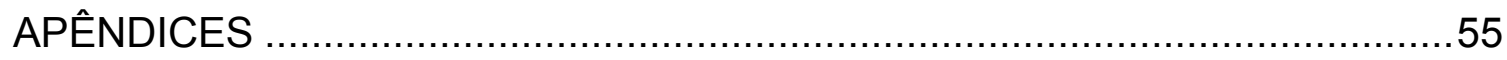

Apêndice 1: Projeção da Carteira de Crédito para o ano de 2006 .......................55 
Apêndice 1: Projeção da Carteira de Depósitos para o ano de 2006..................55

Apêndice 3: Projeção dos Balanços Patrimoniais para o ano de 2006 ...............55

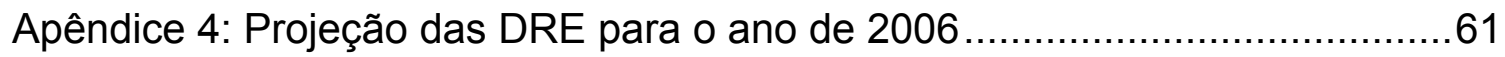

Apêndice 5: Fluxo de dividendos projetados e valores presentes......................61

Apêndice 6: Projeção da Carteira de Crédito para o ano de 2007 .....................62

Apêndice 7: Projeção da Carteira de Depósitos para o ano de 2007.................62

Apêndice 8: Projeção dos Balanços Patrimoniais para o ano de 2007 ...............62

Apêndice 9: Projeção das DRE para o ano de 2007 .....................................68

Apêndice 10: Fluxo de dividendos projetado e valores presentes .....................69

Apêndice 11: Projeção da Carteira de Crédito para o ano de 2008 ....................69

Apêndice 12: Projeção da Carteira de Depósitos para o ano de 2008................69

Apêndice 13: Projeção dos Balanços Patrimoniais para o ano de 2008 ............70

Apêndice 14: Projeção das DRE para o ano de 2008 ....................................75

Apêndice 15: Fluxo de dividendos projetado e valores presentes .....................76 


\section{LISTA DE ILUSTRAÇÕES}

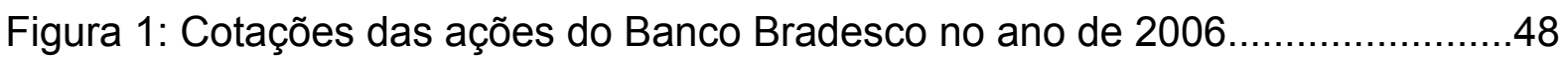

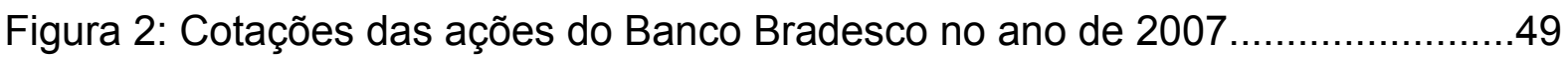

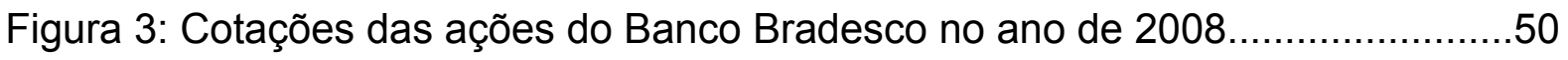




\section{LISTA DE TABELAS}

Tabela 1: Exemplo do Agrupamento das Premissas Macroeconômicas. 38

Tabela 2: Premissas Macroeconômicas projetadas em 2005 para os anos de 2006 a 2012 . .45

Tabela 3: Cálculo do CAPM para o ano de 2006 .45

Tabela 4: Cálculo do Valor presente do banco. 45

Tabela 5: Premissas Macroeconômicas projetadas em 2006 para os anos de 2007 a 2013

Tabela 6: Cálculo do CAPM para o ano de 2007 .46

Tabela 7: Cálculo do Valor presente do banco. 46

Tabela 8: Premissas Macroeconômicas projetadas em 2007 para os anos de 2008 a 2014

Tabela 9: Cálculo do CAPM para o ano de 2008 .47

Tabela 10: Cálculo do Valor presente do banco. .48 


\section{INTRODUÇÃO}

A presente Monografia é o Trabalho de Conclusão de Curso de Administração de Empresas da Universidade de Brasília. O tema de pesquisa escolhido para a Monografia foi o da aplicação do Valuation, ou Avaliação de Empresas, ao setor bancário.

\subsection{Contextualização do Assunto}

A expressão Avaliação de Empresas provém do termo em inglês Valuation, que significa valor estimado, ou, atribuir valor. A gestão do valor passou a ser um conceito fundamental para a administração financeira, sendo utilizada como instrumento de gestão, remuneração de administradores e também em negociações para fusões e aquisições. Considerando que, em última instância, o objetivo de toda organização é maximizar a riqueza dos acionistas, os gestores que se concentrarem na geração de valor criarão empresas mais saudáveis do que os que não o fizerem.

Dentre as principais situações que a Avaliação de Empresas tem contribuição primordial, podemos citar as compras e vendas de negócios, fusões, cisões e incorporações de empresas, dissoluções de sociedades, liquidações de empreendimentos e avaliação da habilidade de gestores.

Existem inúmeras formas de Avaliação de Empresas, porém, no presente trabalho, o método do Fluxo de Caixa Descontado foi adotado como padrão. Dessa forma, a estimativa de valor de uma empresa é composta basicamente por três fases: Projeção do fluxo de caixa futuro da empresa, a determinação da taxa de desconto para o fluxo de caixa projetado e o cálculo do valor presente do fluxo de caixa pela taxa de desconto definida.

O modelo do Fluxo de Caixa Descontado apresentado na literatura especializada atende a Avaliação de Empresas convencionais, porém, algumas empresas fogem a esse padrão. Empresas com alta intervenção do Estado, ou que possuam regras contábeis diferenciadas, por exemplo.

Empresas do setor bancário se enquadram fora do padrão retro mencionado, pois possuem peculiaridades nos seus balanços, nos seus modelos de 
negócio e intervenção estatal, impossibilitando que o Valuation seja aplicado da forma convencional em bancos.

A literatura carece de material que oriente a Avaliação de Bancos e o presente trabalho, visa propor um modelo de montagem de Fluxo de Caixa Descontado que atenda a Avaliação de Bancos.

\subsection{Descrição da situação problemática}

As instituições bancárias possuem peculiaridades em relação a empresas convencionais. Dentre elas podemos citar as diferenças nos demonstrativos contábeis, a intervenção estatal e o modelo de negócios em si.

De acordo com a Resolução CMN 2.999, de 1994, os bancos múltiplos são instituições financeiras privadas ou públicas que realizam as operações ativas, passivas e acessórias das diversas instituições financeiras, por intermédio das seguintes carteiras: comercial, de investimento e/ou de desenvolvimento, de crédito imobiliário, de arrendamento mercantil e de crédito, financiamento e investimento. Essas operações estão sujeitas às mesmas normas legais e regulamentares aplicáveis às instituições singulares correspondentes às suas carteiras. A carteira de desenvolvimento somente poderá ser operada por banco público. O banco múltiplo deve ser constituído com, no mínimo, duas carteiras, sendo uma delas, obrigatoriamente, comercial ou de investimento, e ser organizado sob a forma de sociedade anônima. As instituições com carteira comercial podem captar depósitos à vista. Na sua denominação social deve constar a expressão "Banco"

Ainda de acordo com a Resolução CMN 2.999, de 1994, os bancos comerciais são instituições financeiras privadas ou públicas que têm como objetivo principal proporcionar suprimento de recursos necessários para financiar, a curto e a médio prazos, o comércio, a indústria, as empresas prestadoras de serviços, as pessoas físicas e terceiros em geral. A captação de depósitos à vista, livremente movimentáveis, é atividade típica do banco comercial, o qual pode também captar

Os bancos comerciais e múltiplos têm como funções básicas: receber depósitos e emprestar dinheiro. O lucro do banco é basicamente a diferença entre os juros recebidos e os juros pagos. Podemos inferir, portanto, que o funcionamento de um banco é completamente diferente de uma empresa de bens de serviço ou bens de produção. 
Assim como empresas mercantis tem como objetivo a compra e venda de mercadorias; empresas industriais, a transformação de matérias-primas em produtos; as empresas agrícolas e pastoris, o cultivo, a exploração de terras e das criações; as empresas bancárias têm como objetivo o comércio do dinheiro, seja como fornecedora de recursos financeiros, seja como depositária de recursos de terceiros ou como intermediadora de crédito.

Uma das peculiaridades contábeis que um banco apresenta é a inexistência do Lucro antes de juros, impostos, depreciação e amortização - EBITDA em seus relatórios financeiros, que gera um grande impacto em termos de análise econômico financeira. Além disso, no Brasil, os bancos estão sujeitos a regulação firme do Governo em suas operações. As principais imposições de acordo com o Banco Central do Brasil são: A necessidade de capital mínimo, necessidade de depósitos compulsórios, índice de imobilização, limites de empréstimos, restrições de crédito e requisitos contábeis e estatísticos.

Apesar de toda a peculiaridade do setor bancário e de sua extrema importância para a economia, não existem publicações buscando a compreensão de valor das instituições bancárias. Seria necessário compreender os fatores que mais impactam no valor dos bancos, os drivers, ou vetores de valor. Dessa forma, identificar os principais drivers do setor e aplicá-los a um modelo de Avaliação de Bancos seria de extrema contribuição para os agentes econômicos e para as próprias instituições financeiras.

\subsection{Objetivo Geral}

Identificar os principais drivers de valor dos bancos e propor um modelo de montagem de Fluxo de Caixa Descontado para Avaliação de Bancos.

\subsection{Objetivos Específicos}

Buscou-se atingir os seguintes objetivos específicos:

- Analisar as principais peculiaridades do setor bancário

- Averiguar o melhor método de Fluxo de Caixa Descontado para aplicar em empresas do setor bancário.

- Definir as variáveis que mais influenciam na estimativa de valor de bancos 
- Definir uma metodologia de aplicação das variáveis que mais influenciam no valor de bancos.

- Aplicar a metodologia em dados passados.

- Verificar a aplicabilidade da metodologia proposta.

\subsection{Justificativa}

Diante das peculiaridades nos modelos de negócios dos bancos em relação às demais empresas, bem como suas fontes de receita, custos e riscos de negócio, a forma de auferir o "valor" de um banco se torna igualmente peculiar e complexa.

Outro fato surpreendente é a falta de literatura relacionada ao tema. É possível verificar literatura e artigos referentes ao setor de Energia Elétrica, que assim como o bancário, possui peculiaridades. Porém, a análise do setor bancário é carente em termos acadêmicos.

Instituições que possuírem um modelo eficiente de Avaliação de Bancos poderão criar grandes oportunidades de investimento tanto no mercado de capitais como na avaliação de fusões e aquisições de empresas do setor bancário.

O desafio de compreender o setor bancário e propor um modelo de análise de instituições financeiras seria um grande passo para um profissional que atue no mercado de capitais, bem como grande contribuição aos agentes econômicos. Os objetivos propostos buscam esse passo.

\subsection{Metodologia (Métodos e Técnicas de Pesquisa):}

O método utilizado no desenvolvimento do trabalho foi caracterizado como indutivo, que será explicado na quarta seção do trabalho.

\subsection{Estrutura da Monografia}

A presente Monografia está dividida em cinco seções: Introdução, Referencial Teórico, Metodologia de Pesquisa, Resultados Obtidos e Conclusão

Foram apresentados na Introdução, breve histórico da metodologia de Avaliação de Empresas, bem como sua aplicabilidade. Adicionalmente, foram introduzidas as peculiaridades de análise do objeto de estudo, o setor bancário. 
Também, foi apresentada a situação problemática, os objetivos que o trabalho almeja atingir e por fim, a metodologia que será utilizada.

O Referencial Teórico contém definições de "valor", de avaliação de empresas, os principais tipos dessa avaliação e um detalhamento do Fluxo de Caixa Descontado e suas aplicações de acordo os principais autores da área de Finanças.

$\mathrm{Na}$ terceira seção são apresentados aspectos referentes a pesquisa realizada: Tipo de pesquisa, a metodologia, as delimitações da pesquisa e a sua caracterização, que foi utilizada para atingir os resultados propostos.

A quarta seção é composta pelo detalhamento dos resultados da pesquisa. São apresentados passo a passo como foi aplicada a metodologia de pesquisa e os resultados obtidos.

A quinta seção apresenta as conclusões do autor, com relação ao modelo de montagem de Fluxo de Caixa Descontado para Avaliar bancos proposto. 


\section{REFERENCIAL TEÓRICO}

Serão apresentados, no referencial teórico, conceitos para a compreensão do valuation e sua aplicação. Os conceitos apresentados são o do Valor do ponto de vista da organização, Avaliação de Empresas e seus principais métodos, um detalhamento do método do Fluxo de Caixa Descontado, bem como seus modelos de aplicação com foco principal no Método dos Dividendos Descontados, de acordo com os principais autores e publicações em Finanças.

Adicionalmente, serão apresentados conceitos básicos referentes a instituições financeiras e o Sistema Financeiro Nacional.

\subsection{Definição de Valor}

Para Ferreira (1999, p. 2044) valor pode ter inúmeros significados, dentre eles: O equivalente em dinheiro ou bens de alguma coisa; Qualidade pela qual determinada pessoa ou coisa é estimável em maior ou menor grau, mérito ou merecimento intrínseco; e maior ou menor apreço que um indivíduo tenha por determinado bem ou serviço, podendo ser esse de uso ou de troca.

Segundo Póvoa (2007, p. 13), o valor justo de uma empresa para os seus donos é o que ela pode gerar de retorno no futuro expresso em valores no presente. Onde são necessários três passos para chegar a esse valor: Projetar o fluxo de caixa da empresa, fixar uma taxa de desconto (Custo de oportunidade) e trazer o fluxo à valor presente pela taxa de desconto.

Para Assaf Neto (2008, p. 177), uma empresa é geradora de valor quando remunera seus acionistas acima de suas expectativas, ou seja, quando o resultado do negócio supera a taxa de retorno exigida pelos donos do capital investido na empresa. Ainda segundo Assaf Neto (2008, p. 432), no contexto das finanças corporativas, o objetivo está na maximização do valor de mercado da empresa. A qualidade das decisões é determinante para a riqueza e essas decisões devem ser tomadas com base na relação de risco e retorno esperados. Portanto, o desempenho operacional da empresa deve ser avaliado pelo valor econômico criado, de maneira consistente com o objetivo da maximização da riqueza de seus acionistas. 
De acordo com Damondaran (1994, p. 1), a idéia de que investidores não pagam mais do que um ativo realmente vale parece óbvia, mas a situação é observada freqüentemente no mercado. A justificativa de que o valor está nos olhos de quem compra é absurda, já que as percepções de valor têm que ter suporte na realidade.

\subsection{Avaliação de Empresas}

Avaliação de Empresas é a forma pela qual, especialistas de finanças buscam calcular ou estimar o valor de mercado das empresas. As avaliações partem de premissas que devem ter rigor e refletem as expectativas do analista, ou do mercado, em relação ao futuro da companhia em análise.

Segundo Póvoa (2007, p. 11), o que mais intriga na avaliação de ativos, ou no Valuation, é que não existe resposta ou metodologia que pode ser considerada como única correta. O mais importante é que através da aplicação de uma teoria específica ou teorias combinadas, atingir não necessariamente um preço, mas uma região de preço para o ativo em questão.

Segundo Assaf Neto (2008, p. 643), a avaliação de empresas não é fundamentada como uma ciência exata, por não possibilitar comprovação absoluta dos resultados. Os fatores utilizados na mensuração buscam retratar a realidade dentro de premissas e hipóteses comportamentais, ou seja, expectativas.

Damodaran (1997, p. 2) propõe que é um mito acreditar que apesar dos modelos de avaliação de empresas utilizarem de dados quantitativos, a avaliação será objetiva. A avaliação chega a valores obtidos através de modelos quantitativos sob o efeito de tendências inseridas no processo. Portanto, o ideal é que essas tendências sejam minimizadas ao máximo, sem que se tenha uma pré-concepção da empresa antes avaliá-la.

Ainda segundo Damodaran (1997, p. 3), outro mito da avaliação de empresas é que uma avaliação bem pesquisada será eterna. Uma avaliação é feita com base em informações específicas da empresa e do mercado. Como conseqüência, ao surgirem novas informações relevantes, o valor da empresa se modificará. 
Para Damodaran (1997, p. 5), o papel da Avaliação de empresas depende do objetivo que se tem em avaliar uma empresa. Os principais motivadores de sua utilização são a avaliação e gestão de carteiras de ações, análise para aquisições de empresas e avaliações nas finanças corporativas. Portanto, a avaliação de empresas. Nas análises e gestão de carteiras de ações, são feitas análises em busca de oportunidades em empresas estejam ou subavaliados ou superavaliados. No caso de aquisições, o comprador deve fazer a análise de um valor justo em que esteja disposto a pagar e o vendedor deve chegar a um preço justo em que esteja disposto vender a empresa. No caso das finanças corporativas, uma boa forma de analisar as decisões gerenciais é por meio do valor da empresa, já que uma empresa bem gerenciada sempre agrega valor. Portanto, o papel da avaliação de empresas nas áreas financeiras é de grande valor.

\subsection{Métodos Tradicionais de Avaliação de Empresas}

Existem diversos métodos de Avaliação de Empresas. Serão descritos abaixo os principais métodos da literatura e considerando que existem diversos modelos de avaliação de empresas, para Martins (2001, p. 82), a escolha deve considerar o propósito da avaliação e as características próprias do empreendimento. Estes modelos são normalmente classificados em técnicas comparativas de mercado, técnicas baseadas em ativos e passivos ajustados, e técnicas baseadas no desconto de fluxos futuros de benefícios.

\subsubsection{Avaliação por Múltiplos}

Segundo Damodaran (1994, Caps. 7 e 8), a análise por múltiplos é uma forma de análise relativa, pois seu objetivo é encontrar o valor do ativo com base nos preços de ativos similares no mercado, ou seja, por comparação.. As comparações são feitas por índices contábeis de receita, liquidez, valor contábil, setorial e de preço. Um exemplo de múltiplo seria o do (Preço / Lucro), muito utilizado por investidores no mercado de ações americano.

Segundo Damodaran (1994, p. 302) a maior vantagem dos múltiplos é a simplicidade de cálculo, porém a análise por múltiplos deve ser criteriosa, devem ser verificados múltiplos de todas as categorias (liquidez, endividamento, valor contábil etc.) para que se tenha visão do todo e evitar análises distorcidas da companhia. 


\subsubsection{Avaliação por meio do Fluxo de Caixa Descontado}

A definição que Assaf Neto (2006, págs. 197 e 198) dá ao Fluxo de Caixa Descontado é a de que esse representa o valor presente de fluxos de caixa futuros de um ativo esperados pelo investidor, descontados a uma taxa que represente o seu custo de oportunidade. O método do Fluxo de Caixa Descontado será detalhado em outra seção

\subsubsection{Avaliação por meio de Opções Reais}

A metodologia das Opções Reais, de acordo com Brigham, Gapenski e Ehrhardt (2001, págs. 501 e 502), leva em consideração as probabilidade dos eventos inerentes à vida da empresa e o poder de decisão que os administradores têm, seja em resposta à mudanças no mercado ou à atitudes dos concorrentes. $O$ processo de avaliação por opções reais pode ser quebrado em três fases: Identificação de uma resposta ótima a uma mudança, determinar o valor da opção real (da mudança) e estruturação da empresa de modo a criar opções reais.

\subsubsection{Preferência pelo Fluxo de Caixa Descontado}

A literatura corrente e os analistas de mercado têm preferência pela utilização do método do Fluxo de Caixa Descontado para avaliar empresas e são motivados, principalmente, pelos princípios da matemática financeira que levam em consideração o valor do dinheiro no tempo. Uma empresa é um ativo gerador de fluxos de caixa e seu valor, portanto, deve representar o valor presente dos fluxos futuros trazidos a uma taxa que represente o custo de oportunidade da empresa ou de seus acionistas.

Segundo Assaf Neto, (2008, p. 643) existem diversos modelos de Avaliação de Empresas, que envolvem pressupostos e subjetividade, porém, pelo maior rigor conceitual e coerência com a moderna teoria de Finanças, é dada prioridade ao modelo de avaliação baseado no Fluxo de Caixa Descontado.

Para Póvoa (2007, p. 105) o Fluxo de Caixa Descontado é o instrumento de precificação de ativos mais completo. Apesar das críticas com relação à precisão do modelo, sua proposta é proporcionar uma faixa de "valores justos" (considerando um risco e um retorno esperados) e não o "valor justo" exato. 


\subsection{O Método do Fluxo de Caixa Descontado}

De acordo com Povoa (2007, Cap. 6), é possível utilizar dois tipos de fluxo de caixa no método do Fluxo de Caixa Descontado: o Fluxo de Caixa Livre para o Acionista - FCFE e o Fluxo de Caixa Livre para a Firma - FCFF. No FCFE, são considerados os valores dos fluxos de capital próprio da empresa e, portanto, os valores após os pagamentos referentes à capital de terceiros da DRE (Despesas Financeiras). No caso do FCFF, são considerados os fluxos a serem distribuídos aos credores e aos acionistas da companhia, ou seja, considera toda a estrutura de capital (Capital Próprio e Capital de Terceiros) da empresa em análise.

Para Bodie, Kane e Marcus (2001, p. 564), o valor intrínseco de uma ação é calculado pelas expectativas de retorno em termos de dividendos e ganhos de capital que um investidor possui para a ação em análise para um determinado período de tempo.

Para Damodaran (2006, Cap. 3), existem três formas de categorizar fluxos de caixa. O primeiro é entre fluxos de caixa para a firma, que consideram todo o capital da empresa e fluxos para os acionistas. Os fluxos para acionistas podem ser os fluxos de dividendos ou os Fluxos de Caixa Livres para os Acionistas. A segunda forma de categorizar é quanto a fluxos nominais ou reais. Os fluxos nominais incorporam a inflação esperada e por isso devem ser representados na moeda específica (reais, ienes ou dólares americanos, por exemplo). Os fluxos reais não contemplam a inflação e verificam apenas as variações no número de unidades vendidas e poder real precificação. A terceira e última forma de categorizar os fluxos é se eles são considerados antes dos impostos ou depois dos impostos. A forma mais comum é a após os impostos. Caso sejam utilizados os fluxos após os impostos, seria necessário aplicar um adicional na taxa de desconto do fluxo para aplicar o efeito dos impostos.

\subsubsection{Fluxos de Caixa}

De acordo com Assaf Neto (2008, p. 142), os fluxos de caixa são as movimentações financeiras do caixa da companhia. Essas movimentações explicam de forma analítica, a variação no saldo de disponibilidades imediatas, ou das aplicações financeiras da empresa. 
Para Brigham e Ehrhardt (2002, p. 39), os fluxos de caixa líquidos são mais utilizados por analistas do que as contas contábeis de resultado apuradas nos relatórios contábeis, pois o Fluxo de Caixa é regido pelo regime de caixa, ou seja, representa as saídas e entradas financeiras efetiva nas empresas. As contas contábeis de resultado são regidas pelo regime de competência e, portanto, consideram receitas e despesas apuradas no período, que podem, porém ser realizadas efetivamente em outro período. Além disso, valores não desembolsáveis são considerados nas contas de resultado.

Para Bodie e Merton, (2002, p. 92), o fluxo de caixa representa todo o dinheiro que entra e sai da empresa em determinado período. Ele difere da Demonstração de Resultado e Exercício, que apresenta as receitas e despesas da empresa. O fluxo de caixa possibilita uma análise em relação ao caixa e a liquidez da empresa, pois até as empresas mais lucrativas podem ter problemas se não possuírem dinheiro em caixa.

\subsubsection{Projeção do Fluxo de Caixa}

De acordo com Damodaran (2004, p. 105) para projetar o fluxo de caixa da companhia é necessário estimar os lucros futuros de acordo com as perspectivas da empresa em termos receitas, despesas e investimentos. Para que sejam estimados os valores futuros de qualquer empresa, é necessário que sejam identificados os vetores de valor da empresa, que podem ser os fatores que influenciam os custos ou as receitas da companhia, e as necessidades de investimento em capital de giro ou de infra-estrutura.

\subsubsection{Taxa de Crescimento}

Para Damodaran (1994, Cap. 4), há uma relação entre as taxas de crescimento passadas e as taxas de crescimento futuras esperadas. Assim, um método de estimar as taxas de crescimento é utilizando médias das taxas passadas, que podem ser médias aritméticas ou geométricas:

1) Média Aritmética - consiste na média simples das taxas de crescimento passadas. É encontrada através da divisão das taxas de crescimento anuais pelo número de períodos analisados; 
2) Média Geométrica - consiste na média composta das taxas de crescimento passadas. É uma medida mais precisa do crescimento quando comparada a média aritmética, especialmente se o crescimento anual tiver sido inconstante. É encontrada pela seguinte fórmula: [(último período - período inicial) ^ 1/número de períodos] - 1 .

Apesar das taxas de crescimento passados serem úteis na previsão de crescimento futuro, não são suficientes para a previsão de taxas futuras. Além das taxas de crescimento passadas, o crescimento é influenciado pelos seguintes fatores:

1) Variância das taxas de crescimento - a utilidade das taxas de crescimento passadas na previsão do crescimento futuro é inversamente relacionada à variância dessas taxas de crescimento. Essa variância pode ser avaliada com o desvio padrão nas taxas de crescimento passadas;

2) Porte da empresa - como fica difícil para as empresas sustentarem altas taxas de crescimento à medida que se tornam maiores, as taxas de crescimento passadas para empresas que cresceram drasticamente em porte e lucros podem ser difíceis de sustentar no futuro.

3) Mudança nas bases - a taxa de crescimento observada é o resultado de decisões básicas tomadas pela empresa no tocante a seu mix de negócios, sua seleção de projetos, sua estrutura de capital e sua política de dividendos. Se uma empresa fizer mudanças em uma ou todas essas dimensões, a taxa de crescimento histórica poderá não ser um indicador confiável para o crescimento futuro. A reestruturação de uma empresa, por exemplo, freqüentemente muda tanto seu mix de ativos quanto o de passivos.

Não é incorreto e, na realidade, pode ser adequado, concluir que a taxa de crescimento histórico não é significativa quando os resultados passados forem negativos, e ignorá-la ao estimar o crescimento futuro. Neste caso, a estimativa pode ser feita a partir dos dados básicos da empresa. 


\subsubsection{Valor da Perpetuidade}

A perpetuidade segundo Povoa (2007, p. 109) é a fase em que a empresa atinge o seu estágio máximo de produtividade, no sentido de manter em níveis estáveis suas receitas, custos e estrutura de capital. Pode-se chamar de maturidade da empresa. Existem duas formas de calcular a perpetuidade. A primeira é a perpetuidade sem crescimento do fluxo de caixa e a segunda é a perpetuidade com crescimento do fluxo de caixa. O cálculo da primeira é obtido pela razão do Fluxo de caixa projetado pela taxa de desconto projetado. O cálculo da segunda é a razão do fluxo de caixa projetado pela diferença entre a taxa de desconto e a taxa de crescimento projetada.

\subsubsection{Taxa de Desconto}

De acordo com Povoa (2007, Cap. 5) existem duas possíveis taxas de desconto. O Capital Asset Pricing Model (CAPM) e o Custo Médio Ponderado de Capital (Weighted Average Cost of Capital - WACC). O primeiro se aplica, quando o fluxo de caixa projetado for ao acionista, ou seja, os lucros após as despesas financeiras. O segundo se aplica quando o fluxo de caixa de referência for o Lucro Operacional.

O cálculo do CAPM assume quatro hipóteses: $\mathrm{A}$ inexistência de custos de transação, total liquidez de compra e venda nos mercados, simetria de informações no mercado e a possibilidade de eliminar o risco de um portifolio por meio da diversificação. A fórmula do CAPM é a seguinte:

$$
\text { RetornoExigido }=R f+\beta(R m-R f)
$$

Onde:

$R f=$ Taxa livre de risco

$R m=$ Retorno médio do mercado ou da carteira do acionista

$\beta=$ Coeficiente de volatilidade em relação a um benchmark.

O CAPM é a expectativa de retorno do acionista com base em uma taxa livre de risco, como as praticadas por títulos do governo, e um prêmio de risco do investimento. 
Segundo Damodaran (1994, p. 251), o Custo Médio Ponderado de Capital CMPC é a média ponderada dos custos dos diversos componentes de financiamento utilizados por uma empresa, incluindo dívida, patrimônio líquido e títulos híbridos. Também devem ser considerados benefícios fiscais e riscos adicionais.

Para Copeland, Koller \& Murrin (2002, p. 205) o Custo Médio Ponderado de Capital é a média ponderada dos custos de todas as fontes de capital da empresa, incluindo endividamento e capital social:

$$
\mathrm{WACC}=k_{b}\left(1-T_{c}\right)(B / V)+K_{p}(P / V)+K_{s}(S / V)
$$

Onde:

$K_{b}=$ Rendimento antes de impostos esperado pelo mercado até o vencimento do endividamento irretratável e não conversível.

$T_{c}=$ Alíquota tributária marginal da entidade objeto da avaliação

$B=$ Valor de mercado do endividamento

$V=$ Valor de mercado da entidade objeto de avaliação $(V=B+P+S)$

$K_{p}=$ Custo após impostos do capital, referente a capital preferencial não-resgatável e não-conversível

$P=$ Valor de mercado do capital preferencial

$K_{s}=$ Custo de oportunidade do capital social tal como determinado pelo mercado.

$S=$ Valor de mercado do capital social

\subsection{Modelo de Desconto de Dividendos - DDM}

De acordo com Brealey, Myers e Marcus (2001, p. 288), o modelo de desconto de dividendos é o valor presente das projeções de pagamentos de dividendos da empresa.

Segundo Damodaran (1994, Cap. 5), o Modelo de Desconto de Dividendos (Discounted Dividend Model - DDM) é o mais antigo método de análise por Fluxo de Caixa Descontado. A lógica do DDM é a de que um investidor observa dois tipos de fluxos ao avaliar um ativo, os dividendos que receberá e o preço de venda do ativo no final do período previsto e considerando que o preço do ativo no final do período 
será o valor dos dividendos futuros até o infinito daquele período em diante, seria possível calcular os dividendos pela seguinte fórmula:

$$
\text { Valor por ação }=\sum_{t=1}^{t=\infty} \frac{E\left(D P S_{t}\right)}{\left(1+k_{e}\right)^{t}}
$$

Onde:

$D P S_{t}=$ Valor da expectativa de dividendos por ação, considerando que os dividendos têm valores constantes.

$K_{e}=$ Custo de oportunidade da ação

Nesse sentido, os inputs básicos do modelo são: a expectativa de dividendos e o custo de oportunidade. O custo de oportunidade pode ser calculado pelo beta de mercado no CAPM.

Ainda segundo Damodaran (1994, Cap.5), foram sendo desenvolvidas evoluções do modelo original de DDM.

\subsubsection{Modelo de Crescimento de Gordon}

Para Damodaran (1994, Cap.5), o modelo de crescimento de Gordon considera uma taxa de crescimento constante no valor dos pagamentos de dividendos ao longo do infinito. Apesar de ser de difícil aplicabilidade, pois deveria ser aplicado a empresas que apresentam um crescimento estável. O DDM seria calculado de acordo com a seguinte fórmula:

$$
\text { Valor da ação }=\frac{D P S_{1}}{K e-g}
$$

Onde:

$D P S_{1}=$ Dividendo esperado para o próximo ano

$K e=$ Taxa de retorno exigida pelo investidor

$g=$ Taxa de crescimento dos dividendos até o infinito

São feitas algumas observações: A primeira é que a estimativa da taxa de crescimento dos dividendos deve ser igual à estimativa da taxa de crescimento dos lucros da empresa, pois caso contrário, no longo prazo, o valor a ser pago nos dividendos seria maior do que o próprio lucro. O segundo ponto é que a taxa de crescimento da empresa não poder ser superior a economia em que ela atue, pois 
caso contrário, ela se tornaria maior que a própria economia, na visão de longo prazo.

O modelo poderia ser usado para empresas que apresentem um crescimento muito estável e próximo de constante. Porém, seria difícil encontrar um caso aplicável dado a volatilidade dos mercados.

\subsubsection{Modelo do DDM em Dois Estágios}

Segundo Damodaran (1994, p. 209), o modelo permite a precificação de dois estágios de crescimento da empresa em análise. Uma fase inicial em que o crescimento não é dado a uma taxa constante e um período subseqüente de maturação, onde a empresa estabiliza o seu crescimento. Empresas têm um crescimento acelerado no início de suas operações, porém o modelo pode ser adaptado para empresas com crescimento inferior no início. $O$ valor da ação será o valor presente do período inicial somado ao valor presente da perpetuidade com crescimento, ou:

$$
\sum_{i=1}^{t=n} \frac{D P S_{t}}{\left(1+k_{e, h g}\right)^{t}}+\frac{P_{n}}{\left(1+k_{e, h g}\right)^{n}} \text { onde } P_{n}=\frac{D P S_{n+1}}{\left(k_{e, s t}-g_{n}\right)}
$$

Onde:

$D P S_{\mathrm{t}}=$ Dividendos por ação esperados para o ano $\mathrm{t}$.

$k_{e}=$ Custo de oportunidade (hg: high growth ou alto crescimento; st: stable growth ou crescimento estável)

$P_{n}=$ Preço no final do ano $\mathrm{n}$

$g=$ Crescimento extraordinário para os anos iniciais

$g_{n}=$ Crescimento constante até o infinito, após o ano $\mathrm{n}$

São feitas as mesmas observações feitas ao modelo de Gordon, já que o modelo é apenas uma adaptação, sendo adicionado um estágio.

Adicionalmente, uma empresa em crescimento acelerado tem uma relação de payout diferente de uma empresa estável. Uma forma de calcular as mudanças de relação de payout nos períodos é utilizando o modelo de crescimento: 


$$
\text { Crescimento esperado } \left.=(1-\text { Payout }){ }^{*} \operatorname{ROE}^{1}\right)
$$

Efetuando manipulações algébricas:

Payout estável $=($ Taxa de Crescimento estável / ROE do período estável $)$

\subsubsection{O Modelo H para Avaliação do Crescimento}

Segundo Damodaran (1994, p. 214), o modelo H é um modelo semelhante ao de dois estágios, porém a taxa de crescimento no período inicial não é constante. $\mathrm{A}$ taxa de crescimento do período inicial do modelo $\mathrm{H}$ diminui gradativamente até alcançar a taxa do período estável. Esse modelo foi proposto por Fuller e Hsia em 1984 e é baseado na idéia de que o crescimento dos lucros é alto inicialmente e declina linearmente até alcançar a taxa de crescimento estável da empresa. Assim como nos modelos anteriores, o modelo assume que a o payout de dividendos e o Custo de Capital não se alteram com as mudanças nas taxas de crescimento. $O$ valor da empresa pode ser calculado da seguinte forma:

$$
P_{0}=\frac{D P S_{t}^{*}\left(1+g_{n}\right)}{\left(k_{e}-g_{n}\right)}+\frac{D P S_{t}^{*} H^{*}\left(g_{a}-g_{n}\right)}{\left(k_{e}-g_{n}\right)}
$$

Onde:

$P_{0}=$ Valor presente da firma por ação

$D P S_{\mathrm{t}}=$ Dividendos esperados para o ano $\mathrm{t}$

$k_{e}=$ Custo de oportunidade

$g_{a}=$ Taxa de Crescimento inicial

$g_{n}=$ Taxa de Crescimento do período estável

O modelo apresenta limitações, pois as taxas de crescimento caem linearmente e dessa forma seria de difícil aplicação em um caso real. Adicionalmente, seria complicado assumir que o payout é constante, dado que, geralmente, quando o crescimento diminui, espera-se aumento do payout.

\subsubsection{O modelo de DDM em Três Fases}

Segundo Damodaran (1994, p. 216), O modelo de Dividendos Descontados em três fases, é o mais dinâmico, pois combina o modelo de duas fases com o

\footnotetext{
${ }^{1} \mathrm{ROE}=$ Return on Equity
} 
modelo $\mathrm{H}$. Esse é o modelo aplicável, pois não restringe mudanças de payout. $\mathrm{O}$ modelo tem três fases. A primeira é composta por um período de alto crescimento constante, o segundo é composto pela queda linear do crescimento até a taxa constante e a terceira e última é a do crescimento de estabilidade da companhia. $\mathrm{O}$ valor presente de uma ação pode ser calculado da seguinte forma:

$$
\sum_{t=1}^{t=n 1} \frac{E P S_{0} *\left(1+g_{a}\right)^{t} * \prod_{a}}{\left(1+k_{e, h g}\right)}+\sum_{t=n 1+1}^{t=n 2} \frac{D P S_{t}}{\left(1+k_{e, t}\right)}+\frac{E P S_{n 2} *\left(1+g_{n}\right) * \prod_{n}}{\left(k_{e, s t}-g_{n}\right)(1+r)^{n}}
$$

Onde:

$E P S_{t}=$ Lucro por ação no ano $\mathrm{t}$

$D P S_{t}=$ Dividendos por ação no ano

$g_{a}=$ Taxa de crescimento no período de alto cresimento

$g_{n}=$ Taxa de crescimento no preíodo de crescimento estável

$\Pi_{a}=$ Payout no período de alto crescimento

$\Pi_{n}=$ Payout no período de crescimento estável

$k_{e}=$ Custo de oportunidade (hg) alto crescimento, (t) transição e (st) crescimento estável

\subsection{Instituições Financeiras}

Para que seja possível avaliar Instituições Financeiras, é necessário compreender o contexto em que essas organizações estão inseridas. Nesse sentido, serão apresentados conceitos de base para compreensão do setor bancário e financeiro.

\subsubsection{O Sistema Financeiro Nacional - SFN}

De acordo com Niyama e Gomes (2008, Cap. 1), o Sistema Financeiro Nacional é, de forma bem abrangente, composto por um conjunto de instituições que se dedicam, de alguma forma, ao trabalho de propiciar condições satisfatórias para a manutenção de um fluxo de recursos entre poupadores e os que têm necessidade de capital. Os órgãos constituintes do SFN são o Conselho Monetário Nacional (CMN), O Conselho de Recursos do Sistema Financeiro Nacional (CRSFN), o Banco Central do Brasil (Bacen), a Comissão de Valores Mobiliários (CVM), as instituições 
financeiras bancárias, as instituições financeiras não bancárias, os bancos múltiplos, as corretoras distribuidoras de títulos e valores mobiliários e os agentes especiais. Sendo que o CMN, o CRSFN, o Bacen e a CVM são órgão normativos do setor.

As instituições financeiras bancárias são os bancos comerciais ${ }^{2}$ e as cooperativas de crédito. Os bancos comerciais são especializados em crédito de curto e médio prazo, que fomentam capital de giro para o comercio, indústria, empresas prestadoras de serviço e pessoas físicas, além de conceder crédito rural. As cooperativas de crédito oferecem operações semelhantes à dos bancos comerciais, porém, são limitados aos associados.

\subsubsection{Plano Contábil das Instituições do Sistema Financeiro Nacional - Cosif}

De acordo com Niyama e Gomes (2008, Cap. 2), órgão responsável pelas normas gerais de contabilidade que instituições financeiras devem seguir é o Conselho Monetário Nacional e as normas específicas são de competência do Banco Central do Brasil. As normas devem, porém, estar em sinergia com a Lei das Sociedades por Ações e ser divulgadas por meio do Plano Contábil das Instituições do Sistema Financeiro Nacional - Cosif.

\subsection{Demonstrações Financeiras de Bancos}

As demonstrações financeiras de bancos apresentam diferenças em relação às empresas convencionais. Serão apresentadas nesse tópico da monografia as demonstrações financeiras de bancos.

\subsubsection{Os Balanços Patrimoniais}

Os balanços patrimoniais de bancos assim como qualquer empresa são compostos pelo Ativo, o Passivo e o Patrimônio Líquido.

O Ativo dos bancos possui grandes linhas no Ativo Circulante e no Realizável em Longo Prazo: Disponibilidades, Aplicações Interfinanceiras de Liquidez, Títulos e Valores Mobiliários, Relações Interfinanceiras, Relações Interdependências, Operações de Crédito, Operações de Arrendamento Mercantil, Outros Créditos, Outros Valores e Bens. No Permanente: Investimentos, Imobilizado 
de Uso, Imobilizado de Arrendamento, Diferido e o Intangível. As contas podem conter aberturas que objetivam detalhar a composição de cada uma das grandes contas do Ativo.

O Passivo dos Bancos possui grandes linhas tanto no Circulante quanto no Exigível de Longo: Depósitos, Captações no Mercado Aberto, Recursos de Emissão de Títulos, Relações Interfinanceiras, Relações Interdependências, Obrigações por Empréstimos, Obrigações por Repasses do País, Obrigações por repasses do Exterior e Outras Obrigações. As contas podem conter aberturas que objetivam detalhar a composição de cada uma das grandes contas do Passivo.

O Patrimônio Líquido é composto pelas seguintes contas: Capital Social, Reservas de Capital, Reservas de Lucro, Ajuste ao Valor de Mercado e Ações em Tesouraria. A conta de Capital Social contém aberturas de Domiciliados no País e de Domiciliados no Exterior.

\subsubsection{Demonstrações de Resultado do Exercício}

As Demonstrações de Resultado do Exercício possuem grandes linhas: Receitas de Intermediação Financeira, Despesas de Intermediação Financeira, Resultado Bruto de Intermediação Financeira, Outras Despesas/Receitas Operacionais, Resultado Operacional, Resultado Não Operacional, Resultado Antes da Tributação, Provisão para Imposto de Renda, Imposto de Renda Diferido, Participações / Contribuições Estatutárias, Reversão dos Juros sobre Capital Próprio, Participações Minoritárias e Lucro / Prejuízo do Exercício. As contas podem conter aberturas que objetivam detalhar a composição de cada uma das grandes contas de resultado da Companhia.

\subsection{Peculiaridades dos Bancos}

Para Copeland, Koller e Murrin (2002, Cap. 21), existem alguns pontos que dificultam a avaliação de instituições financeiras. O primeiro é que bancos não possuem diferenciação clara entre seus ativos e passivos, dado que os bancos possuem autorização para emprestar um determinado percentual de seus passivos e dessa forma, gerar receitas financeiras. O segundo fator seria a dificuldade em

\footnotetext{
${ }^{2}$ As instituições financeiras que foram adotadas como objeto de estudo no presente trabalho são os bancos comerciais.
} 
determinar a qualidade da carteira de crédito das instituições. Outro ponto importante é estimar o lucro proveniente do descasamento entre empréstimos e captações. Por fim, verificar qual dos segmentos do banco que mais impacta no direcionamento do valor da empresa.

De acordo com Niyama e Amaro (2008, p. 21), as instituições financeiras obedecem a regras contáveis específicas para empresas de sua natureza. O órgão regulador dos princípios contábeis a serem adotados por essas instituições é o Banco Central do Brasil e são divulgados por meio do Plano Contábil das Instituições do Sistema Financeiro (Cosif).

Ainda de acordo com Niyama e Gomes (2008, p. xv), os ativos dos bancos são ativos financeiros e não são como os ativos reais convencionais da economia, como os estoques e os ativos imobilizados. 


\section{MÉTODOS E TÉCNICAS DE PESQUISA}

O método utilizado no desenvolvimento do trabalho foi caracterizado como indutivo. Segundo a classificação de Marconi e Lakatos (2009, p. 86), o Método Indutivo fundamenta-se em premissas e leva a conclusões com conteúdo mais amplo do que as premissas utilizadas. Dessa forma leva a conclusões que podem ser consideradas como provavelmente corretas.

Buscou-se identificar, por meio de pesquisa bibliográfica, qual modelo de Fluxo de Caixa Descontado melhor se aplica na avaliação de bancos, bem como os principais drivers, ou direcionadores de valor, para efetuar essas avaliações. Após a identificação pelo levantamento do referencial teórico, foram efetuados back tests (testes em dados passados buscando prever um evento já ocorrido) em três bancos para verificar a aplicabilidade do modelo definido.

\subsection{Delineamento da pesquisa}

A busca por uma forma de avaliar ou chegar ao valor justo de um ativo ou empresa convencional é, de fato, um dos ramos das finanças que têm evoluído massivamente ao longo dos anos. No tocante de avaliação de instituições financeiras, não se pode dizer o mesmo, ao menos em termos acadêmicos. A identificação dos principais vetores de valor e a sua projeção para aplicá-los a um método adequado de avaliação, dada a diferente dinâmica de negócios de instituições financeiras, repele analistas de investimentos a se aprofundarem em metodologias de avaliação dessas instituições.

O estudo buscou, de forma qualitativa, com base na literatura e na observação do mercado, encontrar os principais fatores que influenciam na avaliação de bancos, as principais instituições de intermediação financeira da economia brasileira. Além da identificação dos fatores qualitativos, foram propostas formas de quantificar esses fatores com o objetivo de aplicá-los em um modelo de valuation para obter o valor justo de um banco. 


\subsection{Descrição das variáveis de pesquisa}

Foram observados três tipos de variáveis na pesquisa. O método adequado de Fluxo de Caixa Descontado, os relatórios financeiros dos bancos e as premissas macroeconômicas utilizadas para efetuar a avaliação dos bancos.

\subsubsection{Fluxos de Caixa Descontados}

Como métodos de Fluxo de Caixa Descontado foram apresentados no Referencial Teórico o Fluxo de Caixa Livre para a Firma - FCFF e o Fluxo de Caixa Livre para os acionistas, que pode ser calculado pelo FCFE e pelo DDM.

\subsubsection{Relatórios Financeiros}

Os relatórios financeiros dos bancos utilizados foram o Balanço Patrimonial e a Demonstração de Resultado do Exercício. Dentro dos relatórios financeiros, foram observadas as peculiaridades de um banco. A principal fonte de geração de riqueza de um banco é a diferença entre a sua capacidade de gerar receitas por meio de empréstimos e os custos da captação de recursos por meio de depósitos.

\subsubsection{Premissas Macroeconômicas}

As premissas macroeconômicas são indicadores da situação da economia como um todo, são os fatores que influenciam a economia como um todo. Dentre os principais fatores macroeconômicos podemos citar as taxas de juros, os índices de inflação, as cotações de moedas, o crescimento da economia, dentre outros.

Foram adotadas premissas macroeconômicas realizadas e projetadas. As premissas realizadas são aquelas que de fato ocorreram e impactaram a economia de forma real. As premissas projetadas são aquelas que eram esperadas pelos principais participantes do Sistema Financeiro Nacional.

As premissas realizadas utilizadas foram a Taxa Selic, o crescimento do PIB, a Taxa de Juros de Longo Prazo - TJLP, o Índice de Preços ao Consumidor da FIPE - IPC-FIPE, a taxa de juros SELIC, o Índice Geral de Preços do Mercado da Fundação Getúlio Vargas - IGP-M, a taxa de câmbio médio do dólar americano e a taxa de câmbio de final de período do dólar americano.

As premissas projetadas são as mesmas utilizadas nas realizadas, com a única diferença de que as projetadas foram estimadas com base em expectativas dos principais participantes do SFN. 


\subsection{Participantes do Estudo}

O único participante do estudo foi o banco Bradesco que foi escolhido para realização dos back tests do modelo proposto com o objetivo de averiguar sua aplicabilidade, em termos de valor justo, por ter ações listadas na Bolsa de Valores de São Paulo - Bovespa, significando fácil acesso às informações, tanto do banco em si quanto do valor de suas ações, e também por ser um dos maiores bancos privados do Brasil.

\subsection{Procedimentos e instrumentos utilizados na coleta e análise dos dados}

Serão apresentadas nessa seção as fontes de coleta dos dados utilizados para o desenvolvimento da pesquisa.

\subsubsection{Coleta dos Relatórios Financeiros}

Os relatórios financeiros do Banco Bradesco foram retirados do seu website, na seção de Relações com Investidores. Foram coletados os Balanços Patrimoniais Consolidados da Companhia e as Demonstrações de Resultado de Exercício consolidados dos anos de 2002 a 2008 com o objetivo testar o modelo proposto no trabalho.

\subsubsection{Coleta das Premissas Macroeconômicas}

As premissas macroeconômicas devem ter a fonte mais confiável possível, podendo, porém, ser projetadas de acordo com as expectativas da instituição ou do investidor que efetua a avaliação. Para o presente estudo as premissas realizadas foram coletadas conforme lista abaixo:

- Crescimento do PIB: Extraído do terminal Bloomberg ${ }^{3}$ com fonte do Instituto Brasileiro de Geografia e Estatística

- Taxa SELIC: Extraída do website do Banco Central do Brasil

- TJLP: Extraído do website Banco Nacional de Desenvolvimento Econômico e Social - BNDES

\footnotetext{
${ }^{3}$ O terminal Bloomberg é um computador que possui acesso ao banco de dados de uma das maiores empresas especializadas em prover informações dos mercados financeiros mundiais, a Bloomberg.
} 
- IPC-FIPE: Extraído do website da Fundação Instituto de Pesquisas Econômicas

- IPG-M: Extraído do website Fundação Getúlio Vargas

- Câmbio Médio R\$/US\$: Extraído do terminal Bloomberg, com fonte do Banco Central do Brasil

- Câmbio Final R\$/US\$: Extraído do website Banco Central do Brasil

As premissas macroeconômicas projetadas foram coletadas conforme lista abaixo:

- Crescimento do PIB: Obtido através do relatório FOCUS do BACEN, na categoria TOP FIVE mediana de longo prazo.

- Taxa SELIC: Obtido através do relatório FOCUS do BACEN, na categoria TOP FIVE mediana de longo prazo.

- TJLP: Projetado de acordo com as cotações divulgadas pelo Banco Nacional de Desenvolvimento Econômico e Social - BNDES

- IPC-FIPE: Obtido através do relatório FOCUS do BACEN, na categoria TOP FIVE mediana de longo prazo.

- IPG-M: Obtido através do relatório FOCUS do BACEN, na categoria TOP FIVE mediana de longo prazo.

- Câmbio Médio R\$/US\$: Obtido através do relatório FOCUS do BACEN, na categoria TOP FIVE mediana de longo prazo.

- Câmbio Final R\$/US\$: Obtido através do relatório FOCUS do BACEN, na categoria TOP FIVE mediana de longo prazo.

O relatório FOCUS é a divulgação das expectativas que os maiores bancos e principais participantes do SFN têm com relação aos principais indicadores macroeconômicos futuros. A categoria TOP FIVE do relatório FOCUS é a das expectativas das instituições que historicamente mais acertaram nas projeções passadas.

A Taxa de Juros de Longo Prazo não possui cotações futuras e, portanto, foi projetada de acordo com as expectativas de mercado. 


\subsection{Período de realização da pesquisa}

A pesquisa foi realizada no período de março a junho de 2009 .

\subsection{Comentários sobre o processo da coleta de dados}

Foi utilizado amplamente o software Microsoft Excel para tabular e tratar os demonstrativos financeiros e as premissas macroeconômicas da pesquisa. 


\section{APRESENTAÇÃO E ANÁLISE DOS RESULTADOS DA PESQUISA}

Serão apresentados nessa seção do trabalho os resultados obtidos da pesquisa. Em primeiro lugar serão apresentados as adaptações e agrupamentos feitos nos dados coletados: Balanços Patrimoniais, Demonstrações de Resultado do Exercício e premissas macroeconômicas. Também será apresentada a metodologia de montagem de fluxo de caixa proposta pelo autor, sua aplicação e os resultados obtidos pela realização dos back tests.

\subsection{Agrupamento, ordenação e descrição dos dados coletados}

A presente seção descreverá como os dados coletados foram manipulados para que fossem aplicados no modelo proposto pelo autor no presente trabalho. Os dados manipulados foram os Balanços Patrimoniais do Banco Bradesco, as Demonstrações de Resultado e Exercício da companhia e as premissas macroeconômicas.

\subsubsection{Agrupamento dos Balanços Patrimoniais}

O agrupamento das contas do Balanço seguiu três critérios: A consolidação das contas de curto e longo prazo, o agrupamento das contas em grandes linhas e o agrupamento de ativos e passivos que geram e que não geram receitas e despesas.

As contas de curto e longo prazo, tanto do Ativo como do Passivo foram somadas, pois o que realmente diferencia as contas é o prazo de vencimento das operações e, portanto, não há diferença para efeito de resultado da companhia.

A segunda parte da consolidação das contas foi em "grandes linhas" do balanço, que significa que foram utilizados os grandes agrupamentos de contas do Ativo e do Passivo da companhia, dado que seria de grande complexidade projetar cada uma das aberturas das contas do ativo e do passivo da companhia.

A terceira forma de agrupar as contas foi em termos de geração ou não de receita ou despesas, sendo o ativo separado em ativos que geram despesas, ativos que não geram despesas e no permanente e os passivos agrupados em passivos que geram despesas, passivos que não geram despesas e o Patrimônio Líquido. Segue abaixo uma tabela para ilustrar as consolidações feitas nos Balanços: 


\subsubsection{Agrupamento das Demonstrações de Resultado do Exercício}

As contas das Demonstrações de Resultado do Exercício foram consolidadas em "grandes linhas", que significa que foram utilizados os grandes agrupamentos de contas da DRE da companhia, dado que seria de grande complexidade projetar cada uma das aberturas das contas do ativo e do passivo da companhia.

\subsubsection{Agrupamento das Premissas Macroeconômicas}

As premissas macroeconômicas foram apenas coletadas e agrupadas de acordo com os anos em que eram previstos os valores e taxas. Para os casos em que não havia previsão para anos mais avançados, foi replicado último dado disponível. Segue abaixo tabela para exemplificar.

\begin{tabular}{|l|c|c|c|c|c|c|c|c|}
\hline Premissas & $\mathbf{2 0 0 8}$ & $\mathbf{2 0 0 9}$ & $\mathbf{2 0 1 0}$ & $\mathbf{2 0 1 1}$ & $\mathbf{2 0 1 2}$ & $\mathbf{2 0 1 3}$ & $\mathbf{2 0 1 4}$ & $\mathbf{2 0 1 5}$ \\
\hline Crescimento do PIB & $4,50 \%$ & $4,10 \%$ & $4,00 \%$ & $4,00 \%$ & $4,00 \%$ & $4,00 \%$ & $4,00 \%$ & $4,00 \%$ \\
\hline SELIC & $11,07 \%$ & $10,50 \%$ & $9,71 \%$ & $9,17 \%$ & $8,77 \%$ & $8,77 \%$ & $8,77 \%$ & $8,77 \%$ \\
\hline TJLP & $6,25 \%$ & $6,25 \%$ & $6,25 \%$ & $6,25 \%$ & $6,25 \%$ & $6,25 \%$ & $6,25 \%$ & $6,25 \%$ \\
\hline IPC-FIPE & $4,00 \%$ & $4,00 \%$ & $4,00 \%$ & $4,00 \%$ & $4,00 \%$ & $4,00 \%$ & $4,00 \%$ & $4,00 \%$ \\
\hline IGP-M & $4,00 \%$ & $4,00 \%$ & $4,00 \%$ & $4,00 \%$ & $4,00 \%$ & $4,00 \%$ & $4,00 \%$ & $4,00 \%$ \\
\hline Câmbio Médio & 1,71 & 1,76 & 1,84 & 1,90 & 1,90 & 1,90 & 1,90 & 1,90 \\
\hline Câmbio Final & 1,7 & 1,75 & 1,83 & 1,91 & 1,91 & 1,91 & 1,91 & 1,91 \\
\hline
\end{tabular}

Fonte: Bloomberg, BACEN e BNDES

Tabela 1: Exemplo do Agrupamento das Premissas Macroeconômicas

\subsection{Análise descritiva dos dados}

Serão apresentados nessa seção o modelo de montagem de fluxo de caixa descontado proposto e os back tests realizados.

\subsubsection{Seleção do Método de Fluxo de Caixa Descontado}

Tecnicamente, o cálculo do valor de uma empresa por qualquer método de Fluxo de Caixa Descontado deve chegar ao mesmo resultado, caso tenha partido das mesmas premissas. No caso de bancos, porém, é mais adequado utilizar Fluxos de Caixa Livres para os Acionistas, pois existem limitações técnicas para o cálculo 
por meio dos Fluxos de Caixa Livres para a Firma. Uma das limitações é a de que parte do dinheiro que os bancos captam é por meio de depósitos livres ao invés de recorrer ao mercado de capitais, sendo complicado estimar o custo desse capital. A outra é a de que os spreads entre as receitas dos bancos e o custo de capital são pequenos, em termos percentuais, e qualquer distorção no cálculo do custo de capital levaria a grandes variações no valor do banco. Portanto, seria mais adequado utilizar o Fluxo de Caixa Livre para os Acionistas.

Poderiam ser utilizados, portanto, o FCFE ou o fluxo de dividendos na estimativa do valor das instituições financeiras. No caso do presente trabalho, o fluxo de dividendos foi escolhido como mais adequado para aplicação em bancos, pois manteria simplicidade no modelo.

\subsubsection{Identificação dos Drivers dos Bancos}

Os bancos possuem em sua Demonstração de Resultado do Exercício, grandes linhas: As receitas de intermediação financeira, Despesas de Intermediação Financeira, Receitas e Despesas Operacionais, Provisão para Imposto de Renda, Reversão para Juros Sobre o Capital Próprio e Participações Minoritárias.

As Receitas de Intermediação Financeira são aquelas que derivam das operações de crédito dos bancos, ou seja, aquelas que provêm dos recursos emprestados pelos bancos.

As Despesas de Intermediação Financeira são aquelas que derivam dos depósitos dos bancos, ou seja, aquelas que provêm dos recursos tomados pelos bancos.

As Receitas e Despesas Operacionais são aquelas que provêm de outras atividades dos bancos como prestação de serviços, tarifas, despesas de pessoal, tributárias, dentre outros.

A provisão para Imposto de Renda é calculada com base nos rendimentos do banco e na alíquota de imposto paga pelo banco.

A Reversão para Juros Sobre o Capital Próprio é aquela em que foram revertidos lucros para remuneração aos acionistas por meio de Juros sobre Capital Próprio. 
Por fim, a linha de Participações Minoritárias que remuneram participações minoritárias do banco.

Os drivers, ou vetores de valor dos bancos, foram propostos com base na literatura observada e na observação dos demonstrativos financeiros dos bancos. A principal fonte de geração de riqueza dos bancos é com relação à diferença entre as receitas geradas por empréstimos e os custos pagos pela captação de recursos por meio de depósitos. Dessa forma foram utilizados como vetores de valor os componentes da margem financeira, que são as Receitas de Intermediação Financeira e as Despesas de Intermediação Financeira, que são gerados, respectivamente, pela Carteira de Crédito e pela Carteira de Depósitos dos bancos.

Outro fator muito importante para os bancos é o nível das taxas de Juros correntes no mercado. Pois os juros são a representação da remuneração pelo uso do dinheiro.

Os drivers seriam, portanto, a carteira de crédito do banco, a carteira de depósitos do banco, a margem de rentabilidade da carteira de crédito do banco, a margem de custo dos depósitos do banco e por fim as taxas de juros do mercado.

\subsubsection{Projeção dos Balanços Patrimoniais}

A projeção dos Balanços Patrimoniais foi feita de acordo os Balanços Patrimoniais de cinco anos anteriores ao ano de análise e foram projetados oito anos posteriores ao ano de análise. Os passos para as projeções dos oito anos posteriores ao ano de análise foram o agrupamento de contas do balanço e projeção das linhas com base nos dados macroeconômicos.

As projeções das contas foram feitas com base nas premissas macroeconômicas obtidas. As contas do ativo, com exceção da Carteira de Crédito e do ativo permanente, foram todas projetadas com base na taxa SELIC de cada ano, sendo aplicados os crescimentos de $100 \%$ da taxa SELIC a cada uma das contas. A conta da Carteira de Crédito, que foi identificada como driver de valor, foi projetada em separado. A projeção da Carteira de Crédito foi feita com base na média móvel dos crescimentos históricos de três anos anteriores ao ano de análise, sendo aplicadas as médias móveis para todos os anos projetados. As contas do Ativo Permanente foram projetadas com base nos índices de inflação ou mantidas constantes para os anos futuros. 
As contas do passivo, com exceção da conta de Depósitos, da conta de repasses e da conta de Carteira de Câmbio, foram projetadas com base na taxa SELIC, seguindo a mesma lógica de projeção das contas do ativo. A conta de Depósitos foi calculada em separado por ser um dos principais drivers de valor da análise. A conta de Depósitos foi calculada com base na média móvel dos crescimentos históricos de três anos anteriores ao ano de análise, sendo aplicadas as médias móveis para todos os anos projetados. A conta de repasses foi projetada com base na Taxa de Juros de Longo Prazo - TJLP de cada ano e a conta da Carteira de Câmbio foi projetada com base no índice de inflação da FIPE, o IPCFIPE de cada ano.

As contas do Patrimônio Líquido foram mantidas estáveis, com exceção da conta de reservas de lucro que é o resíduo do lucro do banco mantido em caixa.

\subsubsection{Projeção da DRE}

As Demonstrações de Resultado do Exercício foram projetadas com base nos Balanços Patrimoniais projetados, nas Demonstrações de Resultado passadas e nas projeções macroeconômicas.

As contas de Receitas de Intermediação Financeira foram projetadas através dos seguintes passos: Encontrar as margens históricas da relação Receitas de Intermediação Financeira (DRE)/Carteira de Crédito (Balanço Patrimonial), projetar as margens de cada ano futuro com base na média das margens de três anos anteriores ao ano de análise e aplicar essas margens calculadas aos valores projetados na conta de Carteira de Crédito projetados no Balanço Patrimonial dos respectivos anos, encontrando dessa forma as Receitas de Intermediação Financeiras futuras.

As contas de Despesas de Intermediação Financeira foram projetadas através dos seguintes passos: Encontrar as margens históricas da relação Despesas de Intermediação Financeira (DRE)/Depósitos (Balanço Patrimonial), projetar as margens futuras de cada ano futuro com base na média de três anos anteriores ao ano de análise e aplicar as margens calculadas aos valores projetados na conta de Carteira de Crédito projetada nos Balanços, encontrando dessa forma as Despesas de Intermediação Financeiras futuras. 
As demais contas da DRE foram projetadas a partir da aplicação da taxa SELIC e as provisões de Imposto de Renda foram calculadas com base na alíquota de $30 \%$.

\subsubsection{Cálculo dos Fluxos de Dividendos}

O cálculo dos fluxos de dividendos foi feito com base nos lucros líquidos obtidos nas projeções das Demonstrações de Resultado do Exercício e no payout apurado no ano anterior ao ano de análise. Foi aplicado o percentual de payout dos últimos dividendos pagos pela companhia a cada um dos lucros líquidos projetados, chegando assim a projeção do fluxo de dividendos futuros.

\subsubsection{O Cálculo do DDM}

O Valuation foi feito a partir do fluxo de dividendos projetado e do CAPM, sendo o fluxo de dividendos a projeção de fluxos futuros e o CAPM a taxa de desconto do fluxo. Foram obtidos, para cada ano de análise, os dividendos por ação, dividindo a estimativa do valor dos dividendos pela quantidade de ações em circulação do banco. Os dividendos por ação foram convertidos de reais para dólares americanos e descontados pelo CAPM calculado, chegando ao valor presente dos fluxos projetados em dólares. Os valores presentes foram convertidos para reais de acordo com a cotação de R\$/US\$ da data do cálculo.

Foi calculada uma perpetuidade para o fluxo de acordo com a fórmula com crescimento apresentada no Referencial teórico:

$$
\frac{D P S_{1}}{K e-g}
$$

O crescimento utilizado foi extraído das premissas macroeconômicas, sendo adotado o crescimento do PIB. O valor do dividendo utilizado foi calculado com base no Lucro Líquido do último ano projetado no fluxo, porém com o payout de $70 \%$, pois conforme proposto no Referencial teórico, empresas em maturidade distribuem uma parte maior de seus lucros aos acionistas. A taxa de desconto foi do CAPM. A perpetuidade também foi calculada em dólar e convertida para reais após ter sido trazida a valor presente.

O CAPM foi calculado com base nos seguintes dados:

- Taxa Livre de Risco: Treasury de 10 anos americano. 
- Prêmio de Risco de Carteira: 5\%.

- Beta: Beta calculado com base nas cotações de dois anos das ações do banco.

- Risco Brasil: Somado ao final do cálculo do CAPM.

O CAPM utilizou os treasuries de 10 anos como taxa livre de risco, pois se assumiu que esse seria o custo de oportunidade de um banco e porque os fluxos seriam descontados em dólares norte americanos. O prêmio de risco de mercado é estimado em $5 \%$ por convenção e, portanto, foi utilizada a convenção de mercado. 0 risco Brasil foi adicionado para representar um prêmio de risco adicional pelo banco estar sediado no Brasil e dessa forma representar um adicional de prêmio sistêmico ao custo de oportunidade.

\subsection{Consolidação do Modelo de Montagem de Fluxos de Caixa Descontados para Avaliação de Bancos}

O modelo proposto pelo autor segue os seguintes passos para chegar ao valor intrínseco de um banco:

- Coleta e Agrupamento das demonstrações financeiras em grandes contas

- Coleta das Premissas Macroeconômicas

- Projeção da Carteira de Crédito por meio da média simples dos crescimentos percentuais da conta dos três anos anteriores ao ano projetado.

- Projeção da Carteira de Depósitos por meio da média simples dos crescimentos percentuais da conta dos três anos anteriores ao ano projetado.

- Projeção das demais contas do Balanço Patrimonial pela aplicação da taxa SELIC, com exceção das contas do ativo permanente, que devem ser projetadas pelos índices de inflação, das contas de repasses do passivo, que devem ser projetadas pela TJLP, da Carteira de Câmbio do passivo, que deve ser projetada pelos índices de inflação e do Patrimônio Líquido que mantém as contas constantes, com exceção das reservas de lucro que são o resíduo do lucro mantido em caixa do banco. 
- Projeção das margens de Receitas com Intermediação Financeira pela média simples das margens dos três anos anteriores ao ano de projeção

- Projeção das margens com Despesas com Intermediação Financeira pela média simples das margens dos três anos anteriores ao ano de projeção

- Projeção das demais contas da Demonstração de Resultado do Exercício pela aplicação da taxa SELIC.

- Projeção do Fluxo de Dividendos aplicando o último payout do banco aos Lucros Líquidos projetados na projeção da DRE.

- Cálculo do CAPM utilizando os Treasuries de 10 anos, o Risco Brasil, um prêmio de risco de mercado e o beta do banco.

- Cálculo do valor presente dos fluxos de dividendos

- Cálculo da perpetuidade e do seu valor presente

- A soma do valor presente dos fluxos de dividendos e do valore presente da perpetuidade será o valor presente do banco em análise.

\subsubsection{O Teste do Modelo - Back Tests}

O modelo de projeção do fluxo de dividendos foi testado com a metodologia de back tests. Foram aplicados os modelos nos dados disponíveis no final dos anos de 2005, 2006 e 2007 e a confirmação da aplicabilidade do modelo foi obtido através das cotações das ações do banco Bradesco no ano seguinte aos respectivos anos da aplicação dos modelos.

\subsubsection{Aplicação do modelo no ano de 2005}

O modelo foi aplicado aos dados disponíveis no final de 2005 para averiguar se seria possível estimar o potencial de valor do banco Bradesco no ano de 2006.

O primeiro passo foi o levantamento das premissas macroeconômicas, tendo como resultado da coleta a Tabela apresentada na página seguinte.

Após o levantamento das premissas macroeconômicas, foram coletados os Balanços Patrimoniais dos anos de 2001, 2002, 2003, 2004 e 2005 e aplicados os agrupamentos propostos. As projeções da carteira de crédito e da carteira de depósitos são apresentadas nos apêndices 1 e 2 respectivamente. As projeções 
futuras das contas dos Balanços patrimoniais seguiram a metodologia proposta e são apresentados no Apêndice 3.

\begin{tabular}{|l|c|c|c|c|c|c|c|c|}
\hline Premissas & $\mathbf{2 0 0 5}$ & $\mathbf{2 0 0 6}$ & $\mathbf{2 0 0 7}$ & $\mathbf{2 0 0 8}$ & $\mathbf{2 0 0 9}$ & $\mathbf{2 0 1 0}$ & $\mathbf{2 0 1 1}$ & $\mathbf{2 0 1 2}$ \\
\hline Crescimento do PIB & & $3,50 \%$ & $3,50 \%$ & $3,80 \%$ & $3,50 \%$ & $3,50 \%$ & $3,50 \%$ & $3,50 \%$ \\
\hline SELIC & & $16,06 \%$ & $15,50 \%$ & $15,50 \%$ & $15,50 \%$ & $15,50 \%$ & $15,50 \%$ & $15,50 \%$ \\
\hline TJLP & $9,75 \%$ & $8,78 \%$ & $7,90 \%$ & $7,11 \%$ & $6,40 \%$ & $6,40 \%$ & $6,40 \%$ & $6,40 \%$ \\
\hline IPC-FIPE & $4,53 \%$ & $4,50 \%$ & $4,45 \%$ & $4,40 \%$ & $4,40 \%$ & $4,40 \%$ & $4,40 \%$ & $4,40 \%$ \\
\hline IGP-M & & $4,48 \%$ & $5,10 \%$ & $4,90 \%$ & $5,10 \%$ & $5,10 \%$ & $5,10 \%$ & $5,10 \%$ \\
\hline Câmbio Médio & & 2,26 & 2,38 & 2,46 & 2,53 & 2,53 & 2,53 & 2,53 \\
\hline Câmbio Final & 2,34 & 2,35 & 2,47 & 2,54 & 2,6 & 2,6 & 2,6 & 2,6 \\
\hline
\end{tabular}

Fonte: Bloomberg, BACEN e BNDES

Tabela 2: Premissas Macroeconômicas projetadas em 2005 para os anos de 2006 a 2012

O Apêndice 4 apresenta as projeções feitas nas Demonstrações de Resultado do Exercício projetadas, O Apêndice 5 contém as projeções dos dividendos e os cálculos dos valores presentes dos dividendos de cada ano. $O$ cálculo do CAPM e o a soma dos valores presentes dos fluxos e da perpetuidade estão representados nas tabelas abaixo:

\begin{tabular}{|l|c|}
\hline Risco Brasil & $3,03 \%$ \\
\hline Rf & $4,38 \%$ \\
\hline Prêmio de risco (Rm-Rf) & $5,00 \%$ \\
\hline Beta & 0,911 \\
\hline CAPM & $8,93 \%$ \\
\hline CAPM + Risco Brasil & $11,96 \%$ \\
\hline
\end{tabular}

Tabela 3: Cálculo do CAPM para o ano de 2006

\begin{tabular}{|l|c|}
\hline VP Fluxo R\$ & 6,31 \\
\hline VP Perpetuidade US\$ & 9,34 \\
\hline VP Perpetuidade & 21,67 \\
\hline Valuation & $\mathbf{2 7 , 9 8}$ \\
\hline
\end{tabular}

Tabela 4: Cálculo do Valor presente do banco:

\subsubsection{Aplicação do modelo no ano de 2006}

O modelo foi aplicado aos dados disponíveis no final de 2006 para averiguar se seria possível estimar o potencial de valor do banco Bradesco no ano de 2007. 
O primeiro passo foi o levantamento das premissas macroeconômicas, tendo como resultado da coleta a Tabela apresentada na página seguinte.

\begin{tabular}{|l|c|c|c|c|c|c|c|c|}
\hline Premissas & $\mathbf{2 0 0 6}$ & $\mathbf{2 0 0 7}$ & $\mathbf{2 0 0 8}$ & $\mathbf{2 0 0 9}$ & $\mathbf{2 0 1 0}$ & $\mathbf{2 0 1 1}$ & $\mathbf{2 0 1 2}$ & $\mathbf{2 0 1 3}$ \\
\hline Crescimento do PIB & $3,50 \%$ & $3,50 \%$ & $3,50 \%$ & $3,70 \%$ & $3,75 \%$ & $3,75 \%$ & $3,75 \%$ & $3,75 \%$ \\
\hline SELIC & $16,06 \%$ & $12,16 \%$ & $11,00 \%$ & $10,00 \%$ & $10,00 \%$ & $8,28 \%$ & $8,28 \%$ & $8,28 \%$ \\
\hline TJLP & $8,78 \%$ & $6,85 \%$ & $6,85 \%$ & $6,85 \%$ & $6,85 \%$ & $6,85 \%$ & $6,85 \%$ & $6,85 \%$ \\
\hline IPC-FIPE & $4,50 \%$ & $4,00 \%$ & $4,00 \%$ & $4,00 \%$ & $4,00 \%$ & $4,00 \%$ & $4,00 \%$ & $4,00 \%$ \\
\hline IGP-M & $4,48 \%$ & $4,00 \%$ & $4,00 \%$ & $4,00 \%$ & $4,00 \%$ & $4,00 \%$ & $4,00 \%$ & $4,00 \%$ \\
\hline Câmbio Médio & 2,26 & 2,16 & 2,17 & 2,21 & 2,26 & 2,26 & 2,26 & 2,26 \\
\hline Câmbio Final & 2,14 & 2,15 & 2,21 & 2,24 & 2,28 & 2,28 & 2,28 & 2,28 \\
\hline
\end{tabular}

Fonte: Bloomberg, BACEN e BNDES

Tabela 5: Premissas Macroeconômicas projetadas em 2006 para os anos de 2007 a 2013

Após o levantamento das premissas macroeconômicas, foram coletados os Balanços Patrimoniais dos anos de 2002, 2003, 2004, 2005 e 2006 e aplicados os agrupamentos propostos. As projeções da carteira de crédito e da carteira de depósitos são apresentadas nos apêndices 6 e 7 respectivamente. As projeções futuras das contas dos Balanços patrimoniais seguiram a metodologia proposta e são apresentados no Apêndice 8.

O Apêndice 9 apresenta as projeções feitas nas Demonstrações de Resultado do Exercício projetadas, O Apêndice 10 contém as projeções dos dividendos e os cálculos dos valores presentes dos dividendos de cada ano. $O$ cálculo do CAPM e o a soma dos valores presentes dos fluxos e da perpetuidade estão representados nas tabelas abaixo:

\begin{tabular}{|l|c|}
\hline Risco Brasil & $1,93 \%$ \\
\hline Rf & $4,68 \%$ \\
\hline Prêmio de risco (Rm-Rf) & $5,00 \%$ \\
\hline Beta & 1,049 \\
\hline CAPM & $9,93 \%$ \\
\hline CAPM + Risco Brasil & $11,86 \%$ \\
\hline
\end{tabular}

Tabela 6: Cálculo do CAPM para o ano de 2007

\begin{tabular}{|l|l|}
\hline VP Fluxo R\$ & 10,47 \\
\hline VP Perpetuidade US\$ & 13,50 \\
\hline VP Perpetuidade & 29,02 \\
\hline Valuation & $\mathbf{3 9 , 5 0}$ \\
\hline
\end{tabular}

Tabela 7: Cálculo do Valor presente do banco: 


\subsubsection{Aplicação do modelo no ano de 2007}

O modelo foi aplicado aos dados disponíveis no final de 2007 para averiguar se seria possível estimar o potencial de valor do banco Bradesco no ano de 2008.

O primeiro passo foi o levantamento das premissas macroeconômicas, tendo como resultado da coleta a Tabela abaixo:

\begin{tabular}{|l|c|c|c|c|c|c|c|c|}
\hline Premissas & 2008 & 2009 & 2010 & 2011 & 2012 & 2013 & 2014 & 2015 \\
\hline Crescimento do PIB & $4,50 \%$ & $4,10 \%$ & $4,00 \%$ & $4,00 \%$ & $4,00 \%$ & $4,00 \%$ & $4,00 \%$ & $4,00 \%$ \\
\hline SELIC & $11,07 \%$ & $10,50 \%$ & $9,71 \%$ & $9,17 \%$ & $8,77 \%$ & $8,77 \%$ & $8,77 \%$ & $8,77 \%$ \\
\hline TJLP & $6,25 \%$ & $6,25 \%$ & $6,25 \%$ & $6,25 \%$ & $6,25 \%$ & $6,25 \%$ & $6,25 \%$ & $6,25 \%$ \\
\hline IPC-FIPE & $4,00 \%$ & $4,00 \%$ & $4,00 \%$ & $4,00 \%$ & $4,00 \%$ & $4,00 \%$ & $4,00 \%$ & $4,00 \%$ \\
\hline IGP-M & $4,00 \%$ & $4,00 \%$ & $4,00 \%$ & $4,00 \%$ & $4,00 \%$ & $4,00 \%$ & $4,00 \%$ & $4,00 \%$ \\
\hline Câmbio Médio & 1,71 & 1,76 & 1,84 & 1,9 & 1,9 & 1,9 & 1,9 & 1,9 \\
\hline Câmbio Final & 1,7 & 1,75 & 1,83 & 1,91 & 1,91 & 1,91 & 1,91 & 1,91 \\
\hline
\end{tabular}

Fonte: Bloomberg, BACEN e BNDES

Tabela 8: Premissas Macroeconômicas projetadas em 2007 para os anos de 2008 a 2014

Após o levantamento das premissas macroeconômicas, foram coletados os Balanços Patrimoniais dos anos de 2003, 2004, 2005, 2006 e 2007 e aplicados os agrupamentos propostos. As projeções da carteira de crédito e da carteira de depósitos são apresentadas nos apêndices 11 e 12 respectivamente. As projeções futuras das contas dos Balanços patrimoniais seguiram a metodologia proposta e são apresentados no Apêndice 13.

O Apêndice 14 apresenta as projeções feitas nas Demonstrações de Resultado do Exercício projetadas, O Apêndice 15 contém as projeções dos dividendos e os cálculos dos valores presentes dos dividendos de cada ano. $\mathrm{O}$ cálculo do CAPM e o a soma dos valores presentes dos fluxos e da perpetuidade estão representados nas Tabelas a seguir:

\begin{tabular}{|l|c|}
\hline Risco Brasil & $2,22 \%$ \\
\hline Rf & $4,08 \%$ \\
\hline Prêmio de risco (Rm-Rf) & $5,00 \%$ \\
\hline Beta & 1,084 \\
\hline CAPM & $9,50 \%$ \\
\hline CAPM + Risco Brasil & $11,72 \%$ \\
\hline
\end{tabular}

Tabela 9: Cálculo do CAPM para o ano de 2008 


\begin{tabular}{|l|c|}
\hline VP Fluxo R\$ & 9,76 \\
\hline VP Perpetuidade US\$ & 14,56 \\
\hline VP Perpetuidade & 25,78 \\
\hline Valuation & $\mathbf{3 5 , 5 4}$ \\
\hline
\end{tabular}

Tabela 10: Cálculo do Valor presente do banco:

\subsubsection{Comparação dos Valores Obtidos com as Cotações em Bolsa}

Através da aplicação do modelo proposto foi obtido o valor de $\mathrm{R} \$ 27,98$ para o ano de 2006. Para contrastar o valor obtido com a realidade, segue abaixo o gráfico de cotações das ações do banco Bradesco no ano de 2006 extraído do terminal Bloomberg:

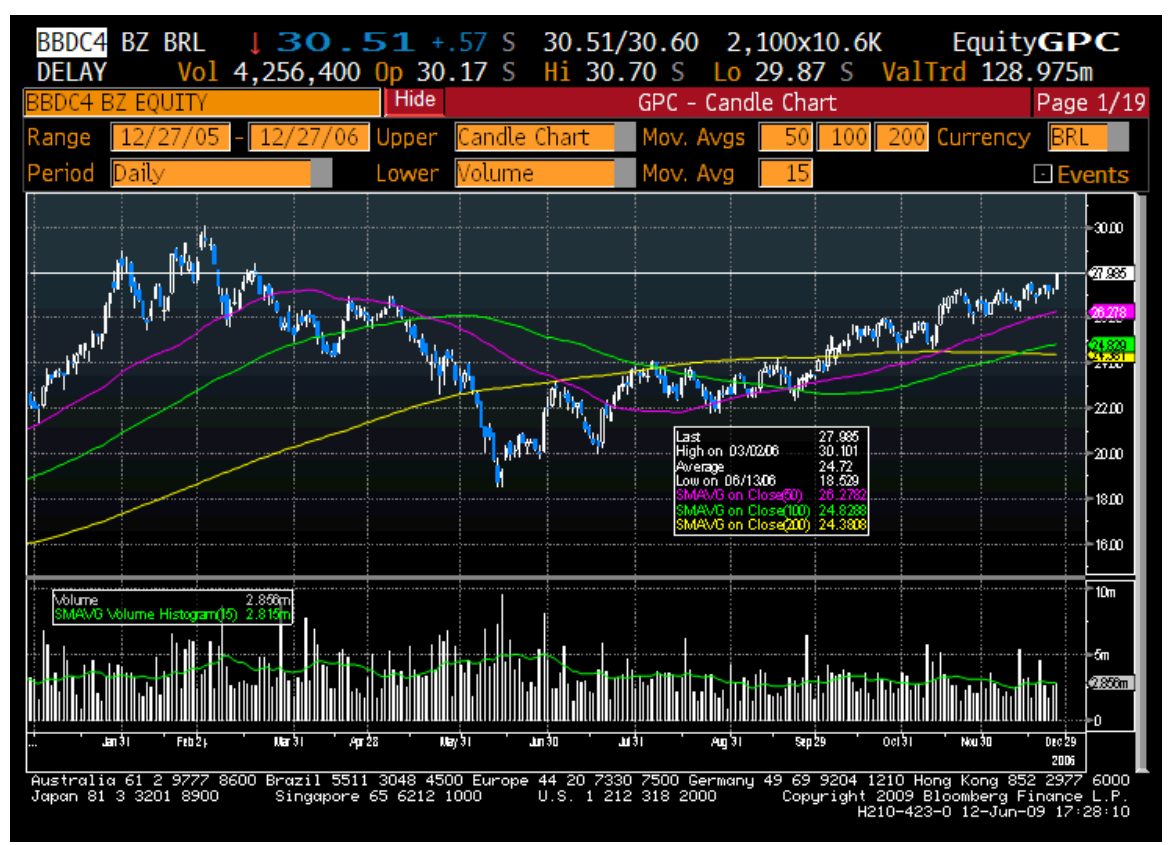

Fonte: Bloomberg

Figura 1: Cotações das ações do Banco Bradesco no ano de 2006

Ao analisar o valor obtido por meio da aplicação do modelo nos dados disponíveis ao final de 2005 , foi obtido justamente o valor de fechamento do último dia do ano de 2006: $R \$ 27,98$. O modelo acertou precisamente o potencial de valorização da ação do Banco Bradesco para o ano de 2006.

Através da aplicação do modelo proposto foi obtido o valor de $\mathrm{R} \$ 39,50$ para o ano de 2007. Para contrastar o valor obtido com a realidade, segue abaixo o gráfico de cotações das ações do banco Bradesco no ano de 2006 extraído do terminal Bloomberg: 


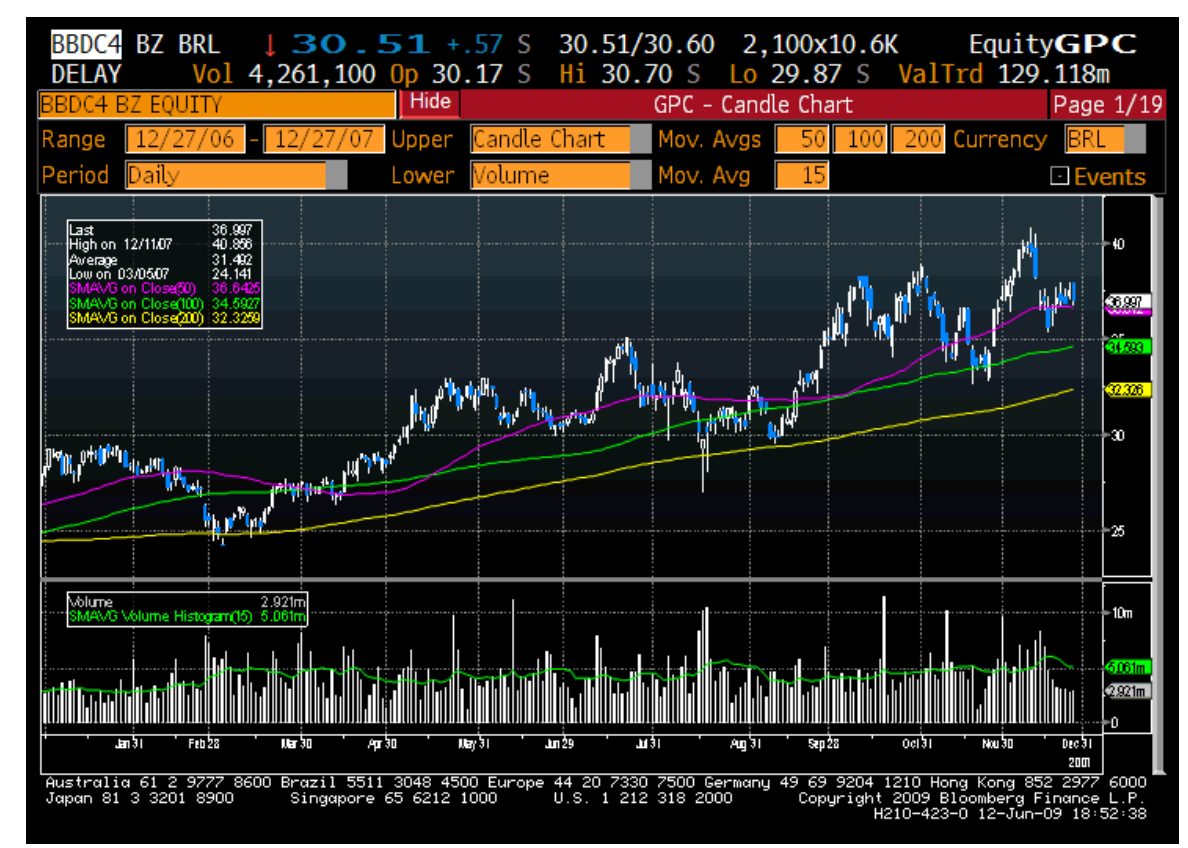

Fonte: Bloomberg

Figura 2: Cotações das ações do Banco Bradesco no ano de 2007

Pôde se observar que se o modelo tivesse sido aplicado ao final de 2006 e utilizado como ferramenta de análise para realizar investimentos em bolsa de valores, o investidor teria obtido bons retornos, dado que a cotação mínima das ações do Bradesco no período foi de $\mathrm{R} \$ 24,14$ e a cotação máxima foi de $\mathrm{R} \$ 40,56$.

Através da aplicação do modelo proposto foi obtido o valor de $\mathrm{R} \$ 35,54$ para o ano de 2008. Para contrastar o valor obtido com a realidade, segue abaixo o gráfico de cotações das ações do banco Bradesco no ano de 2006 extraído do terminal Bloomberg: 


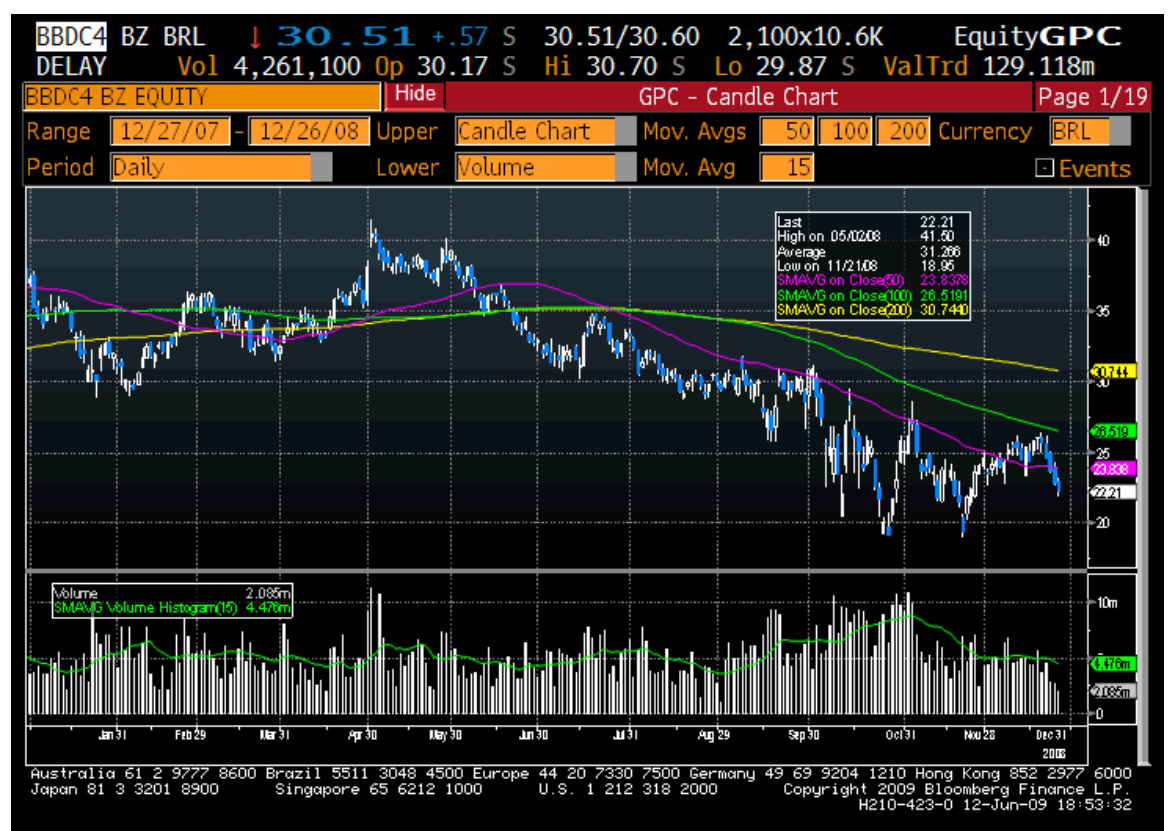

Fonte: Bloomberg

Figura 3: Cotações das ações do Banco Bradesco no ano de 2008

Ao analisar o gráfico de cotações das ações do Banco Bradesco no ano de 2008 em contraste com o valor obtido $(R \$ 35,54)$ por meio da aplicação do modelo proposto pelo autor, concluí-se que os investidores que utilizassem o modelo como ferramenta de análise nos primeiros meses do ano teriam obtido ganhos consideráveis, porém aqueles que realizassem investimentos com base na análise feita do meio do ano em diante teriam provavelmente, obtido prejuízos.

Cabe ressaltar que o ano de 2008 foi marcado por uma das maiores crises de confiança no mercado financeiro de todos os tempos e houve grandes depreciações nos valores de ações de todo o mundo e sendo, portanto, impossível que qualquer modelo de análise preveja uma situação como essa. 


\section{CONCLUSÃO}

Chegou-se a conclusão que o modelo de montagem do fluxo de caixa proposto pelo autor serve de parâmetro para avaliação de bancos, uma vez que foi aplicado ao banco objeto de estudo e verificando-se que caso tivesse sido aplicado no final de 2005 para estimar o valor do banco para o decorrer do ano de 2006, e bem como tivesse sido aplicado no final de 2006 para estimar o valor do banco para o decorrer do ano de 2007 atingiria estimativas aceitáveis para avaliação do Banco Bradesco.

A estimativa do valor do Bradesco para o ano de 2008 atingiu parcialmente o objetivo do modelo. Em virtude desse ano ter sido marcado por uma das maiores crises de confiança da história dos mercados financeiros e, portanto, seria impossível prever os efeitos da crise em um simples modelo de avaliação de empresas. Porém, ainda assim o modelo serviria de parâmetro para compra e venda das ações do banco no primeiro semestre do ano, pois os investidores que o utilizassem no primeiro semestre do ano de 2008 teriam provavelmente obtido lucros.

As peculiaridades do setor bancário estão basicamente na composição de seus lucros, que provém da sua capacidade de captar recursos a um determinado custo e emprestá-los a uma taxa maior que a taxa de captação. Os spreads, que são as diferenças entre as taxas de captação e de investimento dos bancos, são, portanto, o principal driver ou direcionador de valor dos bancos comerciais. No caso do modelo proposto os spreads foram calculados pela margem financeira gerada nos resultados do banco Bradesco.

Outro driver importante para a avaliação de bancos é taxa de juros de mercado, pois essa é a referência que os bancos utilizam para captar e investir recursos. No Brasil, a taxa referência é a SELIC, que é utilizada pelo governo para remunerar os compradores de títulos de dívida pública.

A estimativa das margens financeiras, por médias simples, para projetar os lucros de intermediação financeira, bem como a aplicação da taxa SELIC na projeção das demais contas do Balanço Patrimonial e da Demonstração de Resultado do Exercício foram propostas simples se comparadas a modelos 
utilizados por analistas de investimento e por empresas especializadas em fusões e aquisições, mas, ainda assim, apresentou resultados satisfatórios.

O método dos Dividendos Descontados, utilizado no modelo proposto, mostra-se adequável a bancos, pois seria de extrema complexidade estimar o custo de capital de um banco, dado que parte do capital captado é feito por meio de depósitos livres de custo. Além disso, a estimativa dos dividendos a serem pagos pelos bancos é mais simples de ser feita do que a estimativa dos FCFE, pois é necessário estimar os investimentos que o banco faz para estimar o FCFE e a relação de investimento / resultados de um banco não é simples como a de uma empresa de bens e serviços.

Apesar de ter demonstrado resultados positivos, seria necessário aplicar o modelo a outros bancos para averiguar a sua aplicabilidade em estratégias de investimentos em bolsa de valores e composições de carteiras de investimento.

A identificação dos drivers e da montagem de fluxo propostos não podem ser tomados como verdade absoluta e podem se alterar caso o ambiente das instituições financeiras passem por transformações motivadas por regulamentação, concorrência, pelo surgimento de novas formas de negócio ou qualquer outro motivo. Outra ressalva é que, assim como propõe a literatura especializada, modelos de avaliação de empresas testados em realidades passadas não garantem sua aplicabilidade no presente para prever realidades futuras.

O presente estudo pode ser considerado como o primeiro passo ou como uma provocação para que sejam desenvolvidas novas técnicas ou métodos que sejam aplicáveis à Avaliação de Bancos. 


\section{REFERÊNCIAS}

ASSAF NETO, Alexandre. Finanças Corporativas e Valor. $3^{a}$ Ed., São Paulo: Atlas, 2008.

ASSAF NETO, Alexandre. Mercado Financeiro. $7^{\text {a }}$ Ed., São Paulo: Atlas, 2006.

BODIE, Zvi; KANE, Alex; MARCUS, Alan J. Investments. $5^{\text {a }}$ Ed., Estados Unidos: McGraw Hill Irwin, 2001.

BODIE, Zvi; MERTON, Robert C. Finanças. $1^{\text {a }}$ Ed., Porto Alegre: Bookman Editora, 2002.

BREALEY, Richards A.; MYERS, Stewart C.; ALLEN, Franklin. Principles of Corporate Finance. 9a Ed., Estados Unidos: McGraw Hill Irwin, 2008.

BREALEY, Richards A.; MYERS, Stewart C.; MARCUS, Alan J. Fundamentals of Corporate Finance. $3^{\text {a }}$ Ed., Estados Unidos: McGraw Hill Irwin, 2001.

BRIGHAM, Eugene F.; GAPENSKI, Louis C.; EHRHARDT, Michael C. Administração Financeira: Teoria e Prática. $1^{\text {a }}$ Ed., São Paulo: Atlas, 2001.

BRIGHAM, Eugene F.; HOUSTON, Joel F. Fundamentos da Moderna Administração Financeira. $1^{\text {a }}$ Ed., Rio de Janeiro: Campus,1999.

BRIGHAM, Eugene F.; EHRHARDT, Michael C. Financial Management: Theory and Practice. $10^{\mathrm{a}}$ Ed., Estados Unidos: Thomsom Learning, 2002.

COLLI, José Alexandre; MARINO, Fontana. Contabilidade Bancária. $5^{\mathrm{a}}$ Ed., São Paulo: Atlas, 1996.

COPELAND, Tom; KOLLER, Tim; MURRIN, Jack. Avaliação de Empresas Valuation: Calculando e Gerenciando Valor das Empresas. $3^{\mathrm{a}}$ Ed., São Paulo: Pearson Makron Books, 2002.

DAMODARAN, Aswath. Avaliação de Investimentos: Ferramentas e Técnicas para a Determinação do Valor de Qualquer Ativo. Rio de Janeiro: Qualitymark: 1997.

DAMODARAN, Aswath. Damodaran on Valuation: Security Analysis for Investment and Corporate Finance. Estados Unidos: John Wiley \& Sons, Inc, 1994.

FERREIRA, Aurélio Buarque de Holanda. Novo Aurélio Século XXI: o dicionário da língua portuguesa. $3^{\mathrm{a}}$ Ed., Rio de Janeiro: Nova Fronteira, 1999.

FORTUNA, Eduardo. Mercado Financeiro: Produtos e Serviços. 16 ${ }^{a}$ Ed., Rio de Janeiro: Qualitymark, 2005 
LAKATOS, Eva Maria; MARCONI, Maria de Andrade. Fundamentos de Metogologia Científica. 6ª Ed., São Paulo: Atlas, 2009.

MATARAZZO, Dante Carmine. Análise Financeira de Balanços: Abordagem Básica e Gerencial. 6ª Ed., São Paulo: Atlas, 2008.

NIYAMA, Jorge Katsumi; GOMES, Amaro L. Oliveira. Contabilidade de Instituições Financeiras. $3^{a}$ Ed., São Paulo: Atlas,2008.

PÓVOA, Alexandre. Valuation: Como Precificar Ações. $2^{a}$ Ed.,São Paulo: Globo, 2007. 


\section{APÊNDICES}

Apêndice 1: Projeção da Carteira de Crédito para o ano de 2006

\begin{tabular}{|c|c|c|c|c|c|c|c|c|c|c|c|c|c|}
\hline Ano & 2001 & 2002 & 2003 & 2004 & 2005 & 2006 & 2007 & 2008 & 2009 & 2010 & 2011 & 2012 & 2013 \\
\hline Carteira & 41.137 & 46.239 & 48.815 & 59.017 & 77.990 & 93.229 & 115.787 & 145.076 & 178.459 & 214.903 & 256.504 & 301.868 & 350.729 \\
\hline YoY \% & & $12,4 \%$ & $5,6 \%$ & $20,9 \%$ & $32,1 \%$ & $19,5 \%$ & $24,2 \%$ & $25,3 \%$ & $23,0 \%$ & $20,4 \%$ & $19,4 \%$ & $17,7 \%$ & $16,2 \%$ \\
\hline
\end{tabular}

\section{Apêndice 2: Projeção da Carteira de Depósitos para o ano de 2006}

\begin{tabular}{|c|c|c|c|c|c|c|c|c|c|c|c|c|c|}
\hline Depósitos & 2001 & 2002 & 2003 & 2004 & 2005 & 2006 & 2007 & 2008 & 2009 & 2010 & 2011 & 2012 & 2013 \\
\hline À Vista & 8.058 & 13.370 & 12.909 & 15.298 & 19.428 & 23.022 & 27.282 & 32.330 & 38.313 & 45.402 & 53.803 & 63.758 & 75.556 \\
\hline YoY \% & $0,00 \%$ & $65,93 \%$ & $-3,45 \%$ & $18,50 \%$ & $27,00 \%$ & $14,02 \%$ & $19,84 \%$ & $20,28 \%$ & $18,05 \%$ & $19,39 \%$ & $19,24 \%$ & $18,89 \%$ & $19,17 \%$ \\
\hline Poupança & 18.311 & 20.731 & 22.140 & 24.783 & 26.201 & 31.050 & 36.795 & 43.603 & 51.672 & 61.233 & 72.563 & 85.990 & 101.901 \\
\hline YoY $\%$ & $0,00 \%$ & $13,21 \%$ & $6,80 \%$ & $11,94 \%$ & $5,73 \%$ & $8,15 \%$ & $8,60 \%$ & $7,49 \%$ & $8,08 \%$ & $8,06 \%$ & $7,88 \%$ & $8,01 \%$ & $7,98 \%$ \\
\hline Interfinanceiros & 40 & 24 & 31 & 19 & 146 & 192 & 253 & 333 & 438 & 577 & 759 & 999 & 1.316 \\
\hline YoY \% & $0,00 \%$ & $-41,04 \%$ & $31,67 \%$ & $-37,90 \%$ & $647,17 \%$ & $114,58 \%$ & $136,54 \%$ & $170,56 \%$ & $197,12 \%$ & $242,05 \%$ & $164,59 \%$ & $174,16 \%$ & $181,35 \%$ \\
\hline Prazo & 14.675 & 22.239 & 22.943 & 28.459 & 32.837 & 37.499 & 44.201 & 51.192 & 59.364 & 69.190 & 80.336 & 93.357 & 108.565 \\
\hline YoY \% & $0,00 \%$ & $51,54 \%$ & $3,17 \%$ & $24,04 \%$ & $15,38 \%$ & $14,20 \%$ & $17,87 \%$ & $15,82 \%$ & $15,96 \%$ & $16,55 \%$ & $16,11 \%$ & $16,21 \%$ & $16,29 \%$ \\
\hline $\begin{array}{c}\text { Outros } \\
\text { Depósitos }\end{array}$ & - & - & - & 84 & 266 & 309 & 357 & 412 & 476 & 550 & 635 & 734 & 848 \\
\hline TOTAL & 41.084 & 56.363 & 58.024 & 68.643 & 78.878 & 92.071 & 108.888 & 127.871 & 150.262 & 176.951 & 208.097 & 244.839 & 288.186 \\
\hline YoY \% & & $37,19 \%$ & $2,95 \%$ & $18,30 \%$ & $14,91 \%$ & $16,73 \%$ & $18,26 \%$ & $17,43 \%$ & $17,51 \%$ & $17,76 \%$ & $17,60 \%$ & $17,66 \%$ & $17,70 \%$ \\
\hline
\end{tabular}

\section{Apêndice 3: Projeção dos Balanços Patrimoniais para o ano de 2006}

\begin{tabular}{|c|c|c|c|c|c|c|c|c|c|c|c|c|c|}
\hline Discriminação & 2001 & 2002 & 2003 & 2004 & 2005 & 2006 & 2007 & 2008 & 2009 & 2010 & 2011 & 2012 & 2013 \\
\hline \multicolumn{14}{|l|}{ ATIVO } \\
\hline Disponibilidades & 3.086 & 2.786 & 2.448 & 2.639 & 3.363 & 3.903 & 4.508 & 5.207 & 6.014 & 6.946 & 8.023 & 9.266 & 10.703 \\
\hline TOTAL & 3.086 & 2.786 & 2.448 & 2.639 & 3.363 & 3.903 & 4.508 & 5.207 & 6.014 & 6.946 & 8.023 & 9.266 & 10.703 \\
\hline $\begin{array}{l}\text { Aplicações } \\
\text { Interfinanceiras }\end{array}$ & - & - & - & - & - & - & - & - & - & - & - & - & - \\
\hline $\begin{array}{l}\text { Aplicações no } \\
\text { Mercado Aberto }\end{array}$ & 2.111 & 19.112 & 26.754 & 15.667 & 19.616 & 22.766 & 26.295 & 30.370 & 35.078 & 40.515 & 46.795 & 54.048 & 62.425 \\
\hline $\begin{array}{l}\text { Aplicações em } \\
\text { depósitos } \\
\text { interfinanceiros }\end{array}$ & 1.761 & 2.370 & 4.970 & 6.683 & 5.391 & 6.256 & 7.226 & 8.346 & 9.640 & 11.134 & 12.860 & 14.853 & 17.156 \\
\hline Provisão para & (4) & (9) & - & (3) & $(0)$ & $(0)$ & $(0)$ & $(0)$ & (1) & (1) & (1) & (1) & (1) \\
\hline
\end{tabular}




\begin{tabular}{|c|c|c|c|c|c|c|c|c|c|c|c|c|c|}
\hline Discriminação & 2001 & 2002 & 2003 & 2004 & 2005 & 2006 & 2007 & 2008 & 2009 & 2010 & 2011 & 2012 & 2013 \\
\hline \multicolumn{14}{|l|}{ perdas } \\
\hline TOTAL & 3.867 & 21.473 & 31.724 & 22.347 & 25.006 & 29.022 & 33.521 & 38.716 & 44.717 & 51.648 & 59.654 & 68.900 & 79.580 \\
\hline $\begin{array}{l}\text { Títulos e Valores } \\
\text { Mobiliários }\end{array}$ & 39.932 & 36.765 & 53.572 & 62.024 & 63.976 & 74.251 & 85.760 & 99.053 & 114.406 & 132.139 & 152.620 & 176.276 & 203.599 \\
\hline $\begin{array}{l}\text { Instrumentos } \\
\text { Financeiros } \\
\text { Derivativos }\end{array}$ & 581 & 239 & 232 & 398 & 474 & 551 & 636 & 735 & 849 & 980 & 1.132 & 1.307 & 1.510 \\
\hline TOTAL & 40.513 & 37.003 & 53.805 & 62.422 & 64.451 & 74.802 & 86.396 & 99.787 & 115.254 & 133.119 & 153.752 & 177.584 & 205.109 \\
\hline \multicolumn{14}{|l|}{$\begin{array}{l}\text { Relações } \\
\text { Interfinanceiras }\end{array}$} \\
\hline $\begin{array}{l}\text { Pagamentos e } \\
\text { Recebimentos a } \\
\text { Liquidar }\end{array}$ & 10 & 17 & 20 & 22 & 39 & 45 & 52 & 61 & 70 & 81 & 93 & 108 & 124 \\
\hline $\begin{array}{l}\text { Depósitos no } \\
\text { BACEN }\end{array}$ & 4.907 & 12.520 & 13.580 & 15.696 & 16.445 & 17.182 & 18.058 & 18.943 & 19.909 & 20.924 & 21.991 & 23.113 & 24.292 \\
\hline $\begin{array}{l}\text { SFH - Sistema } \\
\text { Financeiro de } \\
\text { Habitacional }\end{array}$ & 218 & 374 & 392 & 335 & 396 & 460 & 531 & 613 & 708 & 818 & 945 & 1.091 & 1.261 \\
\hline $\begin{array}{l}\text { Correspondentes } \\
\text { e Repasses } \\
\text { Interfinanceiros }\end{array}$ & 8 & 33 & 20 & 34 & 42 & 49 & 56 & 65 & 75 & 87 & 100 & 116 & 134 \\
\hline TOTAL & 5.142 & 12.943 & 14.013 & 16.087 & 16.922 & 17.736 & 18.698 & 19.682 & 20.762 & 21.910 & 23.130 & 24.428 & 25.811 \\
\hline \multicolumn{14}{|l|}{$\begin{array}{l}\text { Relações } \\
\text { Interdependências }\end{array}$} \\
\hline $\begin{array}{l}\text { Relações } \\
\text { Interdependências }\end{array}$ & 176 & 192 & 515 & 148 & 173 & 201 & 232 & 268 & 309 & 357 & 412 & 476 & 550 \\
\hline TOTAL & 176 & 192 & 515 & 148 & 173 & 201 & 232 & 268 & 309 & 357 & 412 & 476 & 550 \\
\hline \multicolumn{14}{|l|}{$\begin{array}{l}\text { Carteira de } \\
\text { Crédito }\end{array}$} \\
\hline $\begin{array}{l}\text { Carteira de } \\
\text { Crédito }\end{array}$ & 41.137 & 46.239 & 48.815 & 59.017 & 77.990 & 93.229 & 115.787 & 145.076 & 178.459 & 214.903 & 256.504 & 301.868 & 350.729 \\
\hline Provisões & $(4.438)$ & $(5.103)$ & $(5.346)$ & $(5.569)$ & $(7.250)$ & $(8.667)$ & $(10.764)$ & $(13.487)$ & $(16.590)$ & $(19.978)$ & $(23.845)$ & $(28.063)$ & $(32.605)$ \\
\hline TOTAL & 36.699 & 41.136 & 43.469 & 53.447 & 70.740 & 84.563 & 105.023 & 131.589 & 161.869 & 194.925 & 232.658 & 273.806 & 318.124 \\
\hline $\begin{array}{l}\text { Carteira de } \\
\text { Câmbio }\end{array}$ & 5.546 & 10.026 & 11.103 & 7.337 & 6.937 & 7.248 & 7.618 & 7.991 & 8.398 & 8.827 & 9.277 & 9.750 & 10.247 \\
\hline $\begin{array}{l}\text { Créditos } \\
\text { Específicos }\end{array}$ & 147 & - & - & - & - & - & - & - & - & - & - & - & - \\
\hline $\begin{array}{l}\text { ATIVOS QUE } \\
\text { GERAM } \\
\text { RECEITA } \\
\end{array}$ & 95.176 & 125.560 & 157.077 & 164.426 & 187.592 & 217.474 & 255.995 & 303.240 & 357.324 & 417.731 & 486.906 & 564.210 & 650.123 \\
\hline
\end{tabular}




\begin{tabular}{|c|c|c|c|c|c|c|c|c|c|c|c|c|c|}
\hline Discriminação & 2001 & 2002 & 2003 & 2004 & 2005 & 2006 & 2007 & 2008 & 2009 & 2010 & 2011 & 2012 & 2013 \\
\hline \multicolumn{14}{|l|}{ Outros Créditos } \\
\hline $\begin{array}{l}\text { Avais e Fianças } \\
\text { Honrados }\end{array}$ & 1 & 2 & 1 & 1 & - & 1 & 1 & 1 & 1 & 2 & 2 & 2 & 3 \\
\hline $\begin{array}{l}\text { Rendas a } \\
\text { Receber }\end{array}$ & 188 & 250 & 331 & 197 & 183 & 212 & 245 & 283 & 327 & 378 & 437 & 504 & 582 \\
\hline $\begin{array}{l}\text { Prêmios de } \\
\text { Seguro a Receber }\end{array}$ & 996 & 921 & 889 & 988 & 1.073 & 1.245 & 1.438 & 1.661 & 1.919 & 2.216 & 2.560 & 2.956 & 3.415 \\
\hline $\begin{array}{l}\text { Negociação e } \\
\text { Intermediação de } \\
\text { Valores }\end{array}$ & 762 & 175 & 603 & 357 & 1.124 & 1.305 & 1.507 & 1.741 & 2.010 & 2.322 & 2.682 & 3.098 & 3.578 \\
\hline Diversos & 8.047 & 9.507 & 11.173 & 12.785 & 12.789 & 13.362 & 15.433 & 17.825 & 20.588 & 23.779 & 27.464 & 31.721 & 36.638 \\
\hline TOTAL & 9.993 & 10.854 & 12.996 & 14.328 & 15.169 & 16.125 & 18.624 & 21.511 & 24.845 & 28.696 & 33.144 & 38.282 & 44.215 \\
\hline \multicolumn{14}{|l|}{$\begin{array}{l}\text { Outros Valores a } \\
\text { Receber }\end{array}$} \\
\hline $\begin{array}{l}\text { Despesas } \\
\text { Antecipadas }\end{array}$ & 348 & 441 & 739 & 1.037 & 1.377 & 1.439 & 1.512 & 1.586 & 1.667 & 1.752 & 1.842 & 1.936 & 2.034 \\
\hline $\begin{array}{l}\text { Outros Valores e } \\
\text { Bens }\end{array}$ & 415 & 680 & 587 & 477 & 368 & 384 & 404 & 424 & 445 & 468 & 492 & 517 & 543 \\
\hline $\begin{array}{l}\text { Provisões para } \\
\text { Desvalorizações }\end{array}$ & $(164)$ & $(244)$ & $(257)$ & $(230)$ & $(181)$ & $(210)$ & $(243)$ & $(280)$ & $(324)$ & $(374)$ & $(432)$ & (499) & $(576)$ \\
\hline TOTAL & 599 & 876 & 1.069 & 1.284 & 1.564 & 1.613 & 1.673 & 1.730 & 1.789 & 1.846 & 1.902 & 1.954 & 2.002 \\
\hline $\begin{array}{l}\text { ATIVOS QUE } \\
\text { NÃO GERAM } \\
\text { RECEITA }\end{array}$ & 10.592 & 11.730 & 14.065 & 15.612 & 16.733 & 17.738 & 20.298 & 23.241 & 26.634 & 30.543 & 35.046 & 40.236 & 46.217 \\
\hline & & & & & & & & & & & & & \\
\hline \multicolumn{14}{|l|}{ Investimentos } \\
\hline $\begin{array}{l}\text { Participações em } \\
\text { Controladas }\end{array}$ & 743 & 395 & 370 & 496 & 439 & 509 & 588 & 679 & 785 & 906 & 1.047 & 1.209 & 1.397 \\
\hline $\begin{array}{l}\text { Outros } \\
\text { Investimentos }\end{array}$ & 453 & 439 & 858 & 971 & 896 & 936 & 984 & 1.032 & 1.085 & 1.140 & 1.198 & 1.259 & 1.323 \\
\hline $\begin{array}{l}\text { Provisão para } \\
\text { perdas de } \\
\text { investimentos }\end{array}$ & $(311)$ & $(322)$ & $(366)$ & $(366)$ & $(350)$ & $(365)$ & $(384)$ & $(403)$ & $(423)$ & $(445)$ & $(468)$ & (491) & $(517)$ \\
\hline TOTAL & 885 & 513 & 862 & 1.101 & 985 & 1.080 & 1.188 & 1.309 & 1.446 & 1.601 & 1.777 & 1.977 & 2.203 \\
\hline \multicolumn{14}{|l|}{ Imobilizado } \\
\hline $\begin{array}{l}\text { Imóveis em uso + } \\
\text { Bens Arrendados }\end{array}$ & 1.476 & 1.748 & 1.399 & 1.357 & 1.116 & 1.116 & 1.116 & 1.116 & 1.116 & 1.116 & 1.116 & 1.116 & 1.116 \\
\hline $\begin{array}{l}\text { Outras } \\
\text { Imobilizações de } \\
\text { uso }\end{array}$ & 3.039 & 3.511 & 3.544 & 3.663 & 3.668 & 3.832 & 4.028 & 4.225 & 4.441 & 4.667 & 4.905 & 5.155 & 5.418 \\
\hline
\end{tabular}




\begin{tabular}{|c|c|c|c|c|c|c|c|c|c|c|c|c|c|}
\hline Discriminação & 2001 & 2002 & 2003 & 2004 & 2005 & 2006 & 2007 & 2008 & 2009 & 2010 & 2011 & 2012 & 2013 \\
\hline $\begin{array}{l}\text { Depreciação } \\
\text { Acumulada }\end{array}$ & $(2.316)$ & $(2.701)$ & $(2.617)$ & $(2.731)$ & $(2.789)$ & $(2.914)$ & $(3.063)$ & $(3.213)$ & $(3.377)$ & (3.549) & $(3.730)$ & $(3.920)$ & $(4.120)$ \\
\hline TOTAL & 2.199 & 2.558 & 2.326 & 2.289 & 1.995 & 2.034 & 2.081 & 2.128 & 2.180 & 2.234 & 2.291 & 2.351 & 2.414 \\
\hline \multicolumn{14}{|l|}{ Intangível } \\
\hline Diferido & 1.265 & 2.412 & 1.768 & 1.497 & 1.378 & 1.599 & 1.847 & 2.134 & 2.464 & 2.846 & 3.287 & 3.797 & 4.385 \\
\hline \multicolumn{14}{|l|}{$\begin{array}{l}\text { Outros Ativos } \\
\text { Intangíveis }\end{array}$} \\
\hline \multicolumn{14}{|l|}{$\begin{array}{l}\text { (Amortização } \\
\text { Acumulada) }\end{array}$} \\
\hline TOTAL & 1.265 & 2.412 & 1.768 & 1.497 & 1.378 & 1.599 & 1.847 & 2.134 & 2.464 & 2.846 & 3.287 & 3.797 & 4.385 \\
\hline PERMANENTE & 4.348 & 5.483 & 4.956 & 4.888 & 4.358 & 4.713 & 5.116 & 5.570 & 6.090 & 6.682 & 7.356 & 8.125 & 9.003 \\
\hline TOTAL ATIVOS & 110.116 & & & 184.926 & & 239.925 & 281.409 & 332.051 & 390.048 & 454.956 & 529.308 & 612.571 & 705.343 \\
\hline \multicolumn{14}{|l|}{$\begin{array}{l}\text { PASSIVO } \\
\text { Depósitos }\end{array}$} \\
\hline À Vista & 8.058 & 13.370 & 12.909 & 15.298 & 15.956 & 23.022 & 27.282 & 32.330 & 38.313 & 45.402 & 53.803 & 63.758 & 75.556 \\
\hline Poupança & 18.311 & 20.731 & 22.140 & 24.783 & 26.201 & 31.050 & 36.795 & 43.603 & 51.672 & 61.233 & 72.563 & 85.990 & 101.901 \\
\hline Interfinanceiros & 40 & 24 & 31 & 19 & 146 & 192 & 253 & 333 & 438 & 577 & 759 & 999 & 1.316 \\
\hline Prazo & 14.675 & 22.239 & 22.943 & 28.459 & 32.837 & 37.499 & 44.201 & 51.192 & 59.364 & 69.190 & 80.336 & 93.357 & 108.565 \\
\hline Outros & - & - & - & 84 & 266 & 309 & 357 & 412 & 476 & 550 & 635 & 734 & 848 \\
\hline TOTAL & 41.084 & 56.363 & 58.024 & 68.643 & 75.406 & 92.071 & 108.888 & 127.871 & 150.262 & 176.951 & 208.097 & 244.839 & 288.186 \\
\hline $\begin{array}{l}\text { Captação } \\
\text { Mercado Aberto }\end{array}$ & - & - & - & - & - & - & 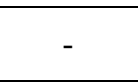 & - & - & - & - & - & 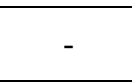 \\
\hline $\begin{array}{l}\text { Própria + Livre de } \\
\text { Movimentação }\end{array}$ & 12.179 & 3.825 & 15.234 & 8.456 & 12.691 & 14.729 & 17.012 & 19.649 & 22.695 & 26.212 & 30.275 & 34.968 & 40.388 \\
\hline de Terceiros & 1.878 & 12.188 & 17.559 & 14.431 & 11.948 & 13.867 & 16.016 & 18.499 & 21.366 & 24.678 & 28.503 & 32.921 & 38.023 \\
\hline TOTAL & 14.057 & 16.013 & 32.793 & 22.886 & 24.639 & 28.596 & 33.028 & 38.148 & 44.061 & 50.890 & 58.778 & 67.888 & 78.411 \\
\hline $\begin{array}{l}\text { Recursos de } \\
\text { Aceite e Emissão } \\
\text { de Títulos }\end{array}$ & - & - & - & - & - & - & - & - & - & - & - & - & - \\
\hline $\begin{array}{l}\text { Recursos de } \\
\text { Debêntures + } \\
\text { Imobiliários }\end{array}$ & 829 & 486 & 1.038 & 681 & 3.472 & 4.030 & 4.655 & 5.376 & 6.210 & 7.172 & 8.284 & 9.568 & 11.051 \\
\hline $\begin{array}{l}\text { Títulos e Valores } \\
\text { Mobiliários no } \\
\text { Exterior }\end{array}$ & 3.972 & 2.651 & 5.809 & 4.376 & 2.731 & 3.170 & 3.662 & 4.229 & 4.885 & 5.642 & 6.516 & 7.526 & 8.693 \\
\hline TOTAL & 4.801 & 3.137 & 6.847 & 5.057 & 6.204 & 7.200 & 8.316 & 9.605 & 11.094 & 12.814 & 14.800 & 17.094 & 19.743 \\
\hline $\begin{array}{l}\text { Relações } \\
\text { Interfinanceiras }\end{array}$ & - & - & - & - & - & - & - & - & - & - & - & - & - \\
\hline Recebimentos e & 5 & 36 & 159 & - & - & - & - & - & - & - & - & - & - \\
\hline
\end{tabular}




\begin{tabular}{|c|c|c|c|c|c|c|c|c|c|c|c|c|c|}
\hline Discriminação & 2001 & 2002 & 2003 & 2004 & 2005 & 2006 & 2007 & 2008 & 2009 & 2010 & 2011 & 2012 & 2013 \\
\hline \multicolumn{14}{|l|}{$\begin{array}{l}\text { Pagamentos à } \\
\text { Liquidar }\end{array}$} \\
\hline Correspondentes & 188 & 571 & 370 & 174 & 139 & 117 & 99 & 83 & 70 & 60 & 50 & 43 & 36 \\
\hline TOTAL & 192 & 607 & 529 & 174 & 139 & 117 & 99 & 83 & 70 & 60 & 50 & 43 & 36 \\
\hline \multicolumn{14}{|l|}{$\begin{array}{l}\text { Relações } \\
\text { Interdependências }\end{array}$} \\
\hline $\begin{array}{l}\text { Recursos em } \\
\text { Trânsito de } \\
\text { Terceiros }\end{array}$ & 763 & 1.338 & 1.782 & 1.746 & 1.901 & 2.206 & 2.548 & 2.943 & 3.399 & 3.926 & 4.535 & 5.238 & 6.049 \\
\hline $\begin{array}{l}\text { Transferência } \\
\text { Interna de } \\
\text { Recursos }\end{array}$ & - & - & - & - & - & - & - & - & - & - & - & - & - \\
\hline TOTAL & 763 & 1.338 & 1.782 & 1.746 & 1.901 & 2.206 & 2.548 & 2.943 & 3.399 & 3.926 & 4.535 & 5.238 & 6.049 \\
\hline \multicolumn{14}{|l|}{$\begin{array}{l}\text { Empréstimos e } \\
\text { Repasses }\end{array}$} \\
\hline Empréstimos & 7.887 & 9.391 & 7.223 & 7.561 & 7.135 & 8.281 & 9.565 & 11.047 & 12.760 & 14.738 & 17.022 & 19.660 & 22.708 \\
\hline Repasses & 6.147 & 7.048 & 7.571 & 8.398 & 9.428 & 10.255 & 11.065 & 11.851 & 12.610 & 13.416 & 14.274 & 15.188 & 16.159 \\
\hline TOTAL & 14.034 & 16.438 & 14.795 & 15.959 & 16.563 & 18.536 & 20.630 & 22.899 & 25.369 & 28.154 & 31.296 & 34.848 & 38.867 \\
\hline $\begin{array}{l}\text { Carteira de } \\
\text { Câmbio }\end{array}$ & 1.344 & 5.002 & 5.119 & 3.011 & 2.207 & 2.306 & 2.409 & 2.515 & 2.626 & 2.741 & 2.862 & 2.988 & 3.119 \\
\hline $\begin{array}{l}\text { Instrumentos } \\
\text { Financeiros } \\
\text { Derivativos }\end{array}$ & 112 & 577 & 52 & 174 & 238 & 277 & 320 & 369 & 426 & 493 & 569 & 657 & 759 \\
\hline $\begin{array}{l}\text { Provisões } \\
\text { Técnicas de } \\
\text { Seguro e } \\
\text { Capitalização }\end{array}$ & 13.853 & 19.155 & 26.409 & 33.669 & 40.863 & 47.425 & 54.776 & 63.266 & 73.073 & 84.399 & 97.481 & 112.590 & 130.042 \\
\hline $\begin{array}{l}\text { PASSIVOS QUE } \\
\text { GERAM } \\
\text { DESPESAS }\end{array}$ & 90.240 & 118.630 & 146.350 & 151.320 & 168.160 & 198.735 & 231.013 & 267.700 & 310.381 & 360.426 & 418.467 & 486.184 & 565.212 \\
\hline $\begin{array}{l}\text { Outras } \\
\text { Obrigações }\end{array}$ & - & - & - & - & - & - & - & - & - & - & - & - & - \\
\hline $\begin{array}{l}\text { Cobrança e } \\
\text { Arrecadação de } \\
\text { Tributos }\end{array}$ & 181 & 108 & 131 & 204 & 156 & 181 & 209 & 242 & 279 & 322 & 372 & 430 & 497 \\
\hline $\begin{array}{l}\text { Sociais e } \\
\text { Estatutárias }\end{array}$ & 572 & 666 & 852 & 900 & 1.255 & 1.456 & 1.682 & 1.943 & 2.244 & 2.591 & 2.993 & 3.457 & 3.993 \\
\hline $\begin{array}{l}\text { Fiscais e } \\
\text { Previdenciárias }\end{array}$ & 3.371 & 4.364 & 4.781 & 4.495 & 5.041 & 5.851 & 6.758 & 7.805 & 9.015 & 10.412 & 12.026 & 13.891 & 16.044 \\
\hline
\end{tabular}




\begin{tabular}{|c|c|c|c|c|c|c|c|c|c|c|c|c|c|}
\hline Discriminação & 2001 & 2002 & 2003 & 2004 & 2005 & 2006 & 2007 & 2008 & 2009 & 2010 & 2011 & 2012 & 2013 \\
\hline $\begin{array}{l}\text { Negociação e } \\
\text { Intermediação de } \\
\text { Valores }\end{array}$ & 1.307 & 109 & 596 & 312 & 894 & 1.038 & 1.198 & 1.384 & 1.599 & 1.846 & 2.133 & 2.463 & 2.845 \\
\hline $\begin{array}{l}\text { Fundos } \\
\text { Financeiros de } \\
\text { Desenvolvimento }\end{array}$ & - & - & 4.995 & - & - & - & - & - & - & - & - & - & - \\
\hline $\begin{array}{l}\text { Dívida } \\
\text { Subordinada }\end{array}$ & 970 & 3.322 & 4.701 & 5.973 & 6.719 & 7.798 & 9.007 & 10.403 & 12.016 & 13.878 & 16.029 & 18.514 & 21.384 \\
\hline $\begin{array}{l}\text { Instrumentos } \\
\text { Híbridos de } \\
\text { Capital }\end{array}$ & - & - & - & - & - & - & - & - & - & - & - & - & - \\
\hline Diversos & 3.558 & 4.440 & - & 6.391 & 6.939 & 8.053 & 9.301 & 10.743 & 12.408 & 14.331 & 16.553 & 19.118 & 22.082 \\
\hline TOTAL & 9.960 & 13.011 & 16.056 & 18.277 & 21.004 & 24.377 & 28.156 & 32.520 & 37.560 & 43.382 & 50.106 & 57.873 & 66.843 \\
\hline $\begin{array}{l}\text { PASSIVOS QUE } \\
\text { NÃO GERAM } \\
\text { DESPESAS }\end{array}$ & 9.960 & 13.011 & 16.056 & 18.277 & 21.004 & 24.377 & 28.156 & 32.520 & 37.560 & 43.382 & 50.106 & 57.873 & 66.843 \\
\hline $\begin{array}{l}\text { Resultado de } \\
\text { Exercícios } \\
\text { Futuros }\end{array}$ & 9 & 16 & 32 & 45 & 52 & 61 & 70 & 81 & 93 & 108 & 124 & 144 & 166 \\
\hline Minoritários & 139 & 271 & 113 & 71 & 58 & 67 & 78 & 90 & 104 & 120 & 139 & 160 & 185 \\
\hline $\begin{array}{l}\text { Patrimônio } \\
\text { Líquido }\end{array}$ & & & & & & & & & & & & & \\
\hline Capital Social & 5.200 & 5.200 & 7.000 & 7.000 & 13.000 & 13.000 & 13.000 & 13.000 & 13.000 & 13.000 & 13.000 & 13.000 & 13.000 \\
\hline $\begin{array}{l}\text { Reservas de } \\
\text { Capital }\end{array}$ & 7 & 7 & 9 & 11 & 36 & 36 & 36 & 36 & 36 & 36 & 36 & 36 & 36 \\
\hline $\begin{array}{l}\text { Reservas de } \\
\text { Reavaliação }\end{array}$ & - & - & - & - & - & - & - & - & - & - & - & - & - \\
\hline $\begin{array}{l}\text { Ajuste de } \\
\text { Avaliação } \\
\text { Patrimonial }\end{array}$ & - & 9 & 479 & 458 & 508 & 508 & 508 & 508 & 508 & 508 & 508 & 508 & 508 \\
\hline $\begin{array}{l}\text { Reservas de } \\
\text { Lucro }\end{array}$ & 4.614 & 5.715 & 6.067 & 7.746 & 5.895 & 3.171 & 8.578 & 18.147 & 28.396 & 37.406 & 46.958 & 54.697 & 59.424 \\
\hline $\begin{array}{l}\text { Ações em } \\
\text { Tesouraria }\end{array}$ & (54) & $(86)$ & (7) & - & (30) & $(30)$ & $(30)$ & $(30)$ & (30) & $(30)$ & (30) & $(30)$ & $(30)$ \\
\hline $\begin{array}{l}\text { PATRIMÔNIO } \\
\text { LÍQUIDO }\end{array}$ & 9.768 & 10.846 & 13.547 & 15.215 & 19.409 & 16.685 & 22.092 & 31.661 & 41.910 & 50.920 & 60.472 & 68.211 & 72.938 \\
\hline PASSIVO E PL & 110.116 & 142.773 & 176.098 & 184.926 & 208.683 & 239.925 & 281.409 & 332.051 & 390.048 & 454.956 & 529.308 & 612.571 & 705.343 \\
\hline
\end{tabular}




\section{Apêndice 4: Projeção das DRE para o ano de 2006}

\begin{tabular}{|c|c|c|c|c|c|c|c|c|c|c|c|c|c|}
\hline Discriminação & 2001 & 2002 & 2003 & 2004 & 2005 & 2006 & 2007 & 2008 & 2009 & 2010 & 2011 & 2012 & 2013 \\
\hline $\begin{array}{l}\text { Receitas de } \\
\text { Intermediação } \\
\text { Financeira }\end{array}$ & 21.412 & 31.913 & 28.034 & 26.203 & 33.701 & 38.219 & 44.307 & 53.808 & 63.089 & 73.799 & 86.536 & 100.259 & 115.707 \\
\hline Margem & $23,93 \%$ & $27,62 \%$ & $19,20 \%$ & $16,68 \%$ & $18,66 \%$ & $18,18 \%$ & $17,84 \%$ & $18,22 \%$ & $18,08 \%$ & $18,05 \%$ & $18,12 \%$ & $18,08 \%$ & $18,08 \%$ \\
\hline $\begin{array}{l}\text { Despesas de } \\
\text { Intermediação } \\
\text { Financeira }\end{array}$ & (13.313) & $(23.260)$ & (17.202) & $(15.014)$ & (18.926) & (21.815) & $(24.760)$ & $(29.402)$ & (33.809) & (39.159) & $(45.670)$ & (52.947) & (61.549) \\
\hline Margem & $-14,75 \%$ & $-19,61 \%$ & $-11,75 \%$ & $-9,92 \%$ & $-11,26 \%$ & $-10,98 \%$ & $-10,72 \%$ & $-10,98 \%$ & $-10,89 \%$ & $-10,86 \%$ & $-10,91 \%$ & $-10,89 \%$ & $-10,89 \%$ \\
\hline Margem & 8.099 & 8.654 & 10.832 & 11.189 & 14.775 & 16.404 & 19.547 & 24.405 & 29.280 & 34.640 & 40.866 & 47.312 & 54.158 \\
\hline $\begin{array}{l}\text { Outras } \\
\text { Despesas/Receitas } \\
\text { Operacionais }\end{array}$ & (6.127) & (7.291) & (7.279) & (7.071) & $(6.921)$ & $(8.033)$ & $(9.278)$ & $(10.716)$ & (12.377) & (14.296) & (16.511) & (19.071) & $(22.026)$ \\
\hline $\begin{array}{l}\text { Resultado } \\
\text { Operacional }\end{array}$ & 1.971 & 1.363 & 3.553 & 4.118 & 7.854 & 8.371 & 10.269 & 13.689 & 16.903 & 20.344 & 24.355 & 28.241 & 32.131 \\
\hline $\begin{array}{l}\text { Resultado Não } \\
\text { Operacional }\end{array}$ & (84) & 186 & $(841)$ & (491) & $(106)$ & $(123)$ & $(142)$ & $(164)$ & $(190)$ & (219) & $(253)$ & $(292)$ & (338) \\
\hline $\begin{array}{l}\text { Resultado Ant. } \\
\text { Trib e Part }\end{array}$ & 1.888 & 1.549 & 2.712 & 3.627 & 7.747 & 8.248 & 10.127 & 13.525 & 16.713 & 20.125 & 24.102 & 27.949 & 31.794 \\
\hline $\begin{array}{l}\text { Provisão para IR e } \\
\text { Contribuição } \\
\text { Social }\end{array}$ & $(502)$ & $(460)$ & $(397)$ & $(554)$ & $(2.224)$ & $(2.474)$ & $(3.038)$ & $(4.057)$ & $(5.014)$ & $(6.038)$ & $(7.231)$ & $(8.385)$ & (9.538) \\
\hline Reversão de JSCP & 803 & 947 & - & - & - & - & - & - & - & - & - & - & - \\
\hline $\begin{array}{l}\text { Participações } \\
\text { Minoritárias }\end{array}$ & (19) & (13) & (9) & $(12)$ & (9) & (9) & (9) & (9) & (9) & (9) & (9) & (9) & (9) \\
\hline $\begin{array}{l}\text { Lucro/Prejuízo } \\
\text { Exercício }\end{array}$ & 2.170 & 2.023 & 2.306 & 3.060 & 5.514 & 5.765 & 7.080 & 9.459 & 11.691 & 14.079 & 16.862 & 19.555 & 22.247 \\
\hline
\end{tabular}

\section{Apêndice 5: Fluxo de dividendos projetados e valores presentes}

\begin{tabular}{|c|c|c|c|c|c|c|c|c|c|c|}
\hline Discriminação & 2005 & 2006 & 2007 & 2008 & 2009 & 2010 & 2011 & 2012 & 2013 & 2014 \\
\hline Payout & $35,90 \%$ & $35,90 \%$ & $35,90 \%$ & $35,90 \%$ & $35,90 \%$ & $35,90 \%$ & $35,90 \%$ & $35,90 \%$ & $35,90 \%$ & $70,00 \%$ \\
\hline Lucro Líquido & - & 5.765 & 7.080 & 9.459 & 11.691 & 14.079 & 16.862 & 19.555 & 22.247 & 22.247 \\
\hline Dividendos & - & 2.070 & 2.542 & 3.396 & 4.197 & 5.054 & 6.054 & 7.020 & 7.987 & 15.573 \\
\hline Qtd de Ações & 3070 & 3070 & 3070 & 3070 & 3070 & 3070 & 3070 & 3070 & 3070 & 3070 \\
\hline DPS & - & 0,67 & 0,83 & 1,11 & 1,37 & 1,65 & 1,97 & 2,29 & 2,60 & 5,07 \\
\hline DPS US\$ & - & 0,29 & 0,34 & 0,44 & 0,53 & 0,63 & 0,76 & 0,88 & 1,00 & 1,95 \\
\hline VPL DPS US\$ & - & 0,26 & 0,27 & 0,31 & 0,33 & 0,36 & 0,39 & 0,40 & 0,41 & \\
\hline
\end{tabular}




\begin{tabular}{|l|c|c|c|c|c|c|c|c|c|c|}
\hline Discriminação & $\mathbf{2 0 0 5}$ & $\mathbf{2 0 0 6}$ & $\mathbf{2 0 0 7}$ & $\mathbf{2 0 0 8}$ & $\mathbf{2 0 0 9}$ & $\mathbf{2 0 1 0}$ & $\mathbf{2 0 1 1}$ & $\mathbf{2 0 1 2}$ & $\mathbf{2 0 1 3}$ & $\mathbf{2 0 1 4}$ \\
\hline VPL DPS R\$ & & 0,59 & 0,62 & 0,72 & 0,78 & 0,84 & 0,89 & 0,93 & 0,94 & \\
\hline
\end{tabular}

\section{Apêndice 6: Projeção da Carteira de Crédito para o ano de 2007}

\begin{tabular}{|c|c|c|c|c|c|c|c|c|c|c|c|c|c|}
\hline Ano & 2002 & 2003 & 2004 & 2005 & 2006 & 2007 & 2008 & 2009 & 2010 & 2011 & 2012 & 2013 & 2014 \\
\hline Car & 6.239 & 48.815 & 59.017 & 77.990 & 93.484 & 116.205 & 145.768 & 179.592 & 218.896 & 265.211 & 318.927 & 380.646 & 451.362 \\
\hline YoY \% & $12,4 \%$ & $5,6 \%$ & $20,9 \%$ & $32,1 \%$ & $19,9 \%$ & $24,3 \%$ & $25,4 \%$ & $23,2 \%$ & $21,9 \%$ & $21,2 \%$ & $20,3 \%$ & $19,4 \%$ & $18,6 \%$ \\
\hline
\end{tabular}

\section{Apêndice 7: Projeção da Carteira de Depósitos para o ano de 2007}

\begin{tabular}{|c|c|c|c|c|c|c|c|c|c|c|c|c|c|}
\hline & 2002 & 2003 & 2004 & 2005 & 2006 & 2007 & 2008 & 2009 & 2010 & 2011 & 2012 & 2013 & 2014 \\
\hline \multicolumn{14}{|l|}{ Depósitos } \\
\hline Á Vista & 13.370 & 12.909 & 15.298 & 15.956 & 20.527 & 24.325 & 28.826 & 34.160 & 40.481 & 47.971 & 56.848 & 67.367 & 79.832 \\
\hline YoY \% & $65,93 \%$ & $-3,45 \%$ & $18,50 \%$ & $4,30 \%$ & $28,65 \%$ & $17,15 \%$ & $16,70 \%$ & $20,83 \%$ & $18,23 \%$ & $18,59 \%$ & $19,22 \%$ & $18,68 \%$ & $18,83 \%$ \\
\hline Poupança & 20.731 & 22.140 & 24.783 & 26.201 & 27.612 & 32.721 & 38.776 & 45.951 & 54.453 & 64.529 & 76.469 & 90.619 & 107.386 \\
\hline YoY \% & $13,21 \%$ & $6,80 \%$ & $11,94 \%$ & $5,73 \%$ & $5,38 \%$ & $7,68 \%$ & $6,26 \%$ & $6,44 \%$ & $6,80 \%$ & $6,50 \%$ & $6,58 \%$ & $6,63 \%$ & $6,57 \%$ \\
\hline Interfinanceiros & 24 & 31 & 19 & 146 & 290 & 382 & 503 & 662 & 872 & 1.148 & 1.511 & 1.989 & 2.620 \\
\hline YoY \% & $-41,04 \%$ & $31,67 \%$ & $-37,90 \%$ & $647,17 \%$ & $99,05 \%$ & $134,20 \%$ & $167,84 \%$ & $193,99 \%$ & $238,51 \%$ & $160,05 \%$ & $171,76 \%$ & $178,97 \%$ & $181,11 \%$ \\
\hline Prazo & 22.239 & 22.943 & 28.459 & 32.837 & 34.925 & 40.255 & 45.220 & 50.338 & 56.868 & 63.810 & 71.573 & 80.483 & 90.362 \\
\hline YoY \% & $51,54 \%$ & $3,17 \%$ & $24,04 \%$ & $15,38 \%$ & $6,36 \%$ & $15,26 \%$ & $12,33 \%$ & $11,32 \%$ & $12,97 \%$ & $12,21 \%$ & $12,17 \%$ & $12,45 \%$ & $12,27 \%$ \\
\hline $\begin{array}{l}\text { Outros } \\
\text { Depósitos }\end{array}$ & - & - & 84 & 266 & 551 & 618 & 686 & 755 & 830 & 899 & 973 & 1.054 & 1.141 \\
\hline TOTAL & 56.363 & 58.024 & 68.643 & 75.406 & 83.905 & 98.301 & 114.011 & 131.866 & 153.504 & 178.357 & 207.375 & 241.512 & 281.341 \\
\hline YoY \% & $37,19 \%$ & $2,95 \%$ & $18,30 \%$ & $9,85 \%$ & $11,27 \%$ & $17,16 \%$ & $15,98 \%$ & $15,66 \%$ & $16,41 \%$ & $16,19 \%$ & $16,27 \%$ & $16,46 \%$ & $16,49 \%$ \\
\hline
\end{tabular}

\section{Apêndice 8: Projeção dos Balanços Patrimoniais para o ano de 2007}

\begin{tabular}{|c|c|c|c|c|c|c|c|c|c|c|c|c|c|}
\hline Discriminação & 2002 & 2003 & 2004 & 2005 & 2006 & 2007 & 2008 & 2009 & 2010 & 2011 & 2012 & 2013 & 2014 \\
\hline \multicolumn{14}{|l|}{ ATIVO } \\
\hline Disponibilidades & 2.786 & 2.448 & 2.639 & 3.363 & 4.762 & 5.341 & 5.929 & 6.521 & 7.174 & 7.768 & 8.411 & 9.107 & 9.861 \\
\hline TOTAL & 2.786 & 2.448 & 2.639 & 3.363 & 4.762 & 5.341 & 5.929 & 6.521 & 7.174 & 7.768 & 8.411 & 9.107 & 9.861 \\
\hline $\begin{array}{l}\text { Aplicações } \\
\text { Interfinanceiras }\end{array}$ & - & - & - & - & - & - & - & - & - & - & - & - & - \\
\hline $\begin{array}{l}\text { Aplicações no } \\
\text { Mercado Aberto }\end{array}$ & 19.112 & 26.754 & 15.667 & 19.616 & 20.617 & 23.124 & 25.668 & 28.234 & 31.058 & 33.629 & 36.414 & 39.429 & 42.694 \\
\hline
\end{tabular}




\begin{tabular}{|c|c|c|c|c|c|c|c|c|c|c|c|c|c|}
\hline Discriminação & 2002 & 2003 & 2004 & 2005 & 2006 & 2007 & 2008 & 2009 & 2010 & 2011 & 2012 & 2013 & 2014 \\
\hline $\begin{array}{l}\text { Aplicações em } \\
\text { depósitos } \\
\text { interfinanceiros }\end{array}$ & 2.370 & 4.970 & 6.683 & 5.391 & 5.373 & 6.026 & 6.689 & 7.358 & 8.094 & 8.764 & 9.490 & 10.276 & 11.126 \\
\hline $\begin{array}{l}\text { Provisão para } \\
\text { perdas }\end{array}$ & (9) & - & (3) & (0) & (1) & (1) & (1) & (1) & (2) & $(2)$ & (2) & (2) & $(2)$ \\
\hline TOTAL & 21.473 & 31.724 & 22.347 & 25.006 & 25.989 & 29.149 & 32.356 & 35.591 & 39.150 & 42.392 & 45.902 & 49.703 & 53.818 \\
\hline $\begin{array}{l}\text { Títulos e Valores } \\
\text { Mobiliários }\end{array}$ & 36.765 & 53.572 & 62.024 & 63.976 & 96.701 & 108.460 & 120.390 & 132.429 & 145.672 & 157.734 & 170.794 & 184.936 & 200.249 \\
\hline $\begin{array}{l}\text { Instrumentos } \\
\text { Financeiros } \\
\text { Derivativos }\end{array}$ & 239 & 232 & 398 & 474 & 549 & 616 & 683 & 752 & 827 & 896 & 970 & 1.050 & 1.137 \\
\hline TOTAL & 37.003 & 53.805 & 62.422 & 64.451 & 97.250 & 109.076 & 121.074 & 133.181 & 146.499 & 158.630 & 171.764 & 185.986 & 201.386 \\
\hline $\begin{array}{l}\text { Relações } \\
\text { Interfinanceiras }\end{array}$ & - & - & - & - & - & - & - & - & - & - & - & - & - \\
\hline $\begin{array}{l}\text { Pagamentos e } \\
\text { Recebimentos a } \\
\text { Liquidar }\end{array}$ & 17 & 20 & 22 & 39 & 51 & 57 & 63 & 70 & 77 & 83 & 90 & 98 & 106 \\
\hline $\begin{array}{l}\text { Depósitos no } \\
\text { BACEN }\end{array}$ & 12.520 & 13.580 & 15.696 & 16.445 & 18.665 & 19.412 & 20.188 & 20.996 & 21.835 & 22.709 & 23.617 & 24.562 & 25.544 \\
\hline $\begin{array}{l}\text { SFH - Sistema } \\
\text { Financeiro de } \\
\text { Habitacional }\end{array}$ & 374 & 392 & 335 & 396 & 406 & 455 & 505 & 556 & 612 & 662 & 717 & 776 & 841 \\
\hline $\begin{array}{l}\text { Correspondentes } \\
\text { e Repasses } \\
\text { Interfinanceiros }\end{array}$ & 33 & 20 & 34 & 42 & 3 & 3 & 4 & 4 & 5 & 5 & 5 & 6 & 6 \\
\hline TOTAL & 12.943 & 14.013 & 16.087 & 16.922 & 19.125 & 19.928 & 20.761 & 21.626 & 22.528 & 23.459 & 24.430 & 25.442 & 26.497 \\
\hline $\begin{array}{l}\text { Relações } \\
\text { Interdependências }\end{array}$ & - & - & - & - & - & - & - & - & - & - & - & - & - \\
\hline $\begin{array}{l}\text { Relações } \\
\text { Interdependências }\end{array}$ & 192 & 515 & 148 & 173 & 186 & 209 & 232 & 255 & 280 & 303 & 329 & 356 & 385 \\
\hline TOTAL & 192 & 515 & 148 & 173 & 186 & 209 & 232 & 255 & 280 & 303 & 329 & 356 & 385 \\
\hline $\begin{array}{l}\text { Carteira de } \\
\text { Crédito }\end{array}$ & - & - & - & - & - & - & - & - & - & - & - & - & - \\
\hline $\begin{array}{l}\text { Carteira de } \\
\text { Crédito }\end{array}$ & 46.239 & 48.815 & 59.017 & 77.990 & 93.484 & 116.205 & 145.768 & 179.592 & 218.896 & 265.211 & 318.927 & 380.646 & 451.362 \\
\hline Provisões & $(5.103)$ & $(5.346)$ & $(5.569)$ & $(7.250)$ & $(10.017)$ & $(12.452)$ & $(15.619)$ & $(19.244)$ & $(23.455)$ & $(28.418)$ & $(34.174)$ & $(40.787)$ & $(48.364)$ \\
\hline TOTAL & 41.136 & 43.469 & 53.447 & 70.740 & 83.467 & 103.754 & 130.149 & 160.349 & 195.440 & 236.793 & 284.753 & 339.859 & 402.998 \\
\hline $\begin{array}{l}\text { Carteira de } \\
\text { Câmbio }\end{array}$ & 10.026 & 11.103 & 7.337 & 6.937 & 7.946 & 8.264 & 8.594 & 8.938 & 9.296 & 9.668 & 10.054 & 10.456 & 10.875 \\
\hline $\begin{array}{l}\text { Créditos } \\
\text { Específicos }\end{array}$ & - & - & - & - & - & - & - & - & - & - & - & - & - \\
\hline
\end{tabular}




\begin{tabular}{|c|c|c|c|c|c|c|c|c|c|c|c|c|c|}
\hline Discriminação & 2002 & 2003 & 2004 & 2005 & 2006 & 2007 & 2008 & 2009 & 2010 & 2011 & 2012 & 2013 & 2014 \\
\hline $\begin{array}{l}\text { ATIVOS QUE } \\
\text { GERAM } \\
\text { RECEITA }\end{array}$ & 125.560 & 157.077 & 164.426 & 187.592 & 238.725 & 275.720 & 319.094 & 366.461 & 420.368 & 479.012 & 545.642 & 620.909 & 705.819 \\
\hline & & & & & & & & & & & & & \\
\hline \multicolumn{14}{|l|}{ Outros Créditos } \\
\hline $\begin{array}{l}\text { Avais e Fianças } \\
\text { Honrados }\end{array}$ & 2 & 1 & 1 & - & - & - & - & - & - & - & - & - & - \\
\hline $\begin{array}{l}\text { Rendas a } \\
\text { Receber }\end{array}$ & 250 & 331 & 197 & 183 & 176 & 197 & 219 & 241 & 265 & 287 & 311 & 337 & 364 \\
\hline $\begin{array}{l}\text { Prêmios de } \\
\text { Seguro a Receber }\end{array}$ & 921 & 889 & 988 & 1.073 & 1.257 & 1.410 & 1.565 & 1.721 & 1.894 & 2.050 & 2.220 & 2.404 & 2.603 \\
\hline $\begin{array}{l}\text { Negociação e } \\
\text { Intermediação de } \\
\text { Valores }\end{array}$ & 175 & 603 & 357 & 1.124 & 709 & 795 & 883 & 971 & 1.068 & 1.156 & 1.252 & 1.356 & 1.468 \\
\hline Diversos & 9.507 & 11.173 & 12.785 & 12.789 & 19.214 & 21.550 & 23.921 & 26.313 & 28.944 & 31.341 & 33.936 & 36.746 & 39.788 \\
\hline TOTAL & 10.854 & 12.996 & 14.328 & 15.169 & 21.356 & 23.953 & 26.588 & 29.246 & 32.171 & 34.835 & 37.719 & 40.842 & 44.224 \\
\hline \multicolumn{14}{|l|}{$\begin{array}{l}\text { Outros Valores a } \\
\text { Receber }\end{array}$} \\
\hline $\begin{array}{l}\text { Despesas } \\
\text { Antecipadas }\end{array}$ & 441 & 739 & 1.037 & 1.377 & 1.794 & 1.866 & 1.940 & 2.018 & 2.099 & 2.183 & 2.270 & 2.361 & 2.455 \\
\hline $\begin{array}{l}\text { Outros Valores e } \\
\text { Bens }\end{array}$ & 680 & 587 & 477 & 368 & 369 & 384 & 399 & 415 & 432 & 449 & 467 & 486 & 505 \\
\hline $\begin{array}{l}\text { Provisões para } \\
\text { Desvalorizações }\end{array}$ & $(244)$ & $(257)$ & $(230)$ & (181) & (189) & $(212)$ & $(235)$ & $(259)$ & $(285)$ & $(308)$ & $(334)$ & $(361)$ & $(391)$ \\
\hline TOTAL & 876 & 1.069 & 1.284 & 1.564 & 1.974 & 2.038 & 2.104 & 2.174 & 2.246 & 2.323 & 2.403 & 2.485 & 2.569 \\
\hline $\begin{array}{l}\text { ATIVOS QUE } \\
\text { NÃO GERAM } \\
\text { RECEITA }\end{array}$ & 11.730 & 14.065 & 15.612 & 16.733 & 23.330 & 25.990 & 28.692 & 31.421 & 34.417 & 37.158 & 40.122 & 43.327 & 46.793 \\
\hline & & & & & & & & & & & & & \\
\hline \multicolumn{14}{|l|}{ Investimentos } \\
\hline $\begin{array}{l}\text { Participações em } \\
\text { Controladas }\end{array}$ & 395 & 370 & 496 & 439 & 403 & 452 & 502 & 552 & 607 & 657 & 712 & 771 & 835 \\
\hline $\begin{array}{l}\text { Outros } \\
\text { Investimentos }\end{array}$ & 439 & 858 & 971 & 896 & 652 & 678 & 705 & 733 & 763 & 793 & 825 & 858 & 892 \\
\hline $\begin{array}{l}\text { Provisão para } \\
\text { perdas de } \\
\text { investimentos }\end{array}$ & $(322)$ & $(366)$ & $(366)$ & $(350)$ & $(358)$ & $(372)$ & $(387)$ & $(403)$ & $(419)$ & $(436)$ & $(453)$ & $(471)$ & $(490)$ \\
\hline TOTAL & 513 & 862 & 1.101 & 985 & 697 & 758 & 820 & 883 & 951 & 1.015 & 1.084 & 1.158 & 1.237 \\
\hline \multicolumn{14}{|l|}{ Imobilizado } \\
\hline Imóveis em uso + & 1.748 & 1.399 & 1.357 & 1.116 & 1.055 & 1.097 & 1.141 & 1.187 & 1.234 & 1.284 & 1.335 & 1.388 & 1.444 \\
\hline
\end{tabular}




\begin{tabular}{|c|c|c|c|c|c|c|c|c|c|c|c|c|c|}
\hline Discriminação & 2002 & 2003 & 2004 & 2005 & 2006 & 2007 & 2008 & 2009 & 2010 & 2011 & 2012 & 2013 & 2014 \\
\hline \multicolumn{14}{|l|}{ Bens Arrendados } \\
\hline $\begin{array}{l}\text { Outras } \\
\text { Imobilizações de } \\
\text { uso }\end{array}$ & 3.511 & 3.544 & 3.663 & 3.668 & 4.127 & 4.292 & 4.464 & 4.642 & 4.828 & 5.021 & 5.222 & 5.431 & 5.648 \\
\hline $\begin{array}{l}\text { Depreciação } \\
\text { Acumulada }\end{array}$ & $(2.701)$ & $(2.617)$ & $(2.731)$ & $(2.789)$ & $(3.030)$ & $(3.151)$ & $(3.277)$ & $(3.408)$ & $(3.545)$ & $(3.686)$ & $(3.834)$ & $(3.987)$ & $(4.147)$ \\
\hline TOTAL & 2.558 & 2.326 & 2.289 & 1.995 & 2.152 & 2.238 & 2.328 & 2.421 & 2.518 & 2.618 & 2.723 & 2.832 & 2.945 \\
\hline \multicolumn{14}{|l|}{ Intangível } \\
\hline Diferido & 2.412 & 1.768 & 1.497 & 1.378 & 643 & 721 & 801 & 881 & 969 & 1.049 & 1.136 & 1.230 & 1.332 \\
\hline \multicolumn{14}{|l|}{$\begin{array}{l}\text { Outros Ativos } \\
\text { Intangíveis }\end{array}$} \\
\hline \multicolumn{14}{|l|}{$\begin{array}{l}\text { (Amortização } \\
\text { Acumulada) }\end{array}$} \\
\hline TOTAL & 2.412 & 1.768 & 1.497 & 1.378 & 643 & 721 & 801 & 881 & 969 & 1.049 & 1.136 & 1.230 & 1.332 \\
\hline PERMANENTE & 5.483 & 4.956 & 4.888 & 4.358 & 3.492 & 3.717 & 3.948 & 4.184 & 4.437 & 4.682 & 4.942 & 5.219 & 5.514 \\
\hline TOTAL ATIVOS & 142.773 & 176.098 & 184.926 & 208.683 & 265.547 & 305.427 & 351.734 & 402.066 & 459.222 & 520.853 & 590.707 & 669.455 & 758.126 \\
\hline \multicolumn{14}{|l|}{ PASSIVO } \\
\hline & & & & & & & & & & & & & \\
\hline \multicolumn{14}{|l|}{ Depósitos } \\
\hline À Vista & 13.370 & 12.909 & 15.298 & 15.956 & 20.527 & 24.325 & 28.826 & 34.160 & 40.481 & 47.971 & 56.848 & 67.367 & 79.832 \\
\hline Poupança & 20.731 & 22.140 & 24.783 & 26.201 & 27.612 & 32.721 & 38.776 & 45.951 & 54.453 & 64.529 & 76.469 & 90.619 & 107.386 \\
\hline Interfinanceiros & 24 & 31 & 19 & 146 & 290 & 382 & 503 & 662 & 872 & 1.148 & 1.511 & 1.989 & 2.620 \\
\hline Prazo & 22.239 & 22.943 & 28.459 & 32.837 & 34.925 & 40.255 & 45.220 & 50.338 & 56.868 & 63.810 & 71.573 & 80.483 & 90.362 \\
\hline Outros & - & - & 84 & 266 & 551 & 618 & 686 & 755 & 830 & 899 & 973 & 1.054 & 1.141 \\
\hline TOTAL & 56.363 & 58.024 & 68.643 & 75.406 & 83.905 & 98.301 & 114.011 & 131.866 & 153.504 & 178.357 & 207.375 & 241.512 & 281.341 \\
\hline \multicolumn{14}{|l|}{$\begin{array}{l}\text { Captação } \\
\text { Mercado Aberto }\end{array}$} \\
\hline $\begin{array}{l}\text { Própria + Livre de } \\
\text { Movimentação }\end{array}$ & 3.825 & 15.234 & 8.456 & 12.691 & 44.204 & 49.579 & 55.033 & 60.536 & 66.590 & 72.103 & 78.074 & 84.538 & 91.538 \\
\hline de Terceiros & 12.188 & 17.559 & 14.431 & 11.948 & 3.472 & 3.894 & 4.323 & 4.755 & 5.230 & 5.663 & 6.132 & 6.640 & 7.190 \\
\hline TOTAL & 16.013 & 32.793 & 22.886 & 24.639 & 47.676 & 53.473 & 59.355 & 65.291 & 71.820 & 77.767 & 84.206 & 91.178 & 98.728 \\
\hline \multicolumn{14}{|l|}{$\begin{array}{l}\text { Recursos de } \\
\text { Aceite e Emissão } \\
\text { de Títulos }\end{array}$} \\
\hline $\begin{array}{l}\text { Recursos de } \\
\text { Debêntures + } \\
\text { Imobiliários }\end{array}$ & 486 & 1.038 & 681 & 3.472 & 3.461 & 3.882 & 4.309 & 4.740 & 5.214 & 5.645 & 6.113 & 6.619 & 7.167 \\
\hline Títulos e Valores & 2.651 & 5.809 & 4.376 & 2.731 & 2.175 & 2.439 & 2.708 & 2.979 & 3.276 & 3.548 & 3.842 & 4.160 & 4.504 \\
\hline
\end{tabular}




\begin{tabular}{|c|c|c|c|c|c|c|c|c|c|c|c|c|c|}
\hline Discriminação & 2002 & 2003 & 2004 & 2005 & 2006 & 2007 & 2008 & 2009 & 2010 & 2011 & 2012 & 2013 & 2014 \\
\hline \multicolumn{14}{|l|}{$\begin{array}{l}\text { Mobiliários no } \\
\text { Exterior }\end{array}$} \\
\hline TOTAL & 3.137 & 6.847 & 5.057 & 6.204 & 5.636 & 6.321 & 7.017 & 7.718 & 8.490 & 9.193 & 9.954 & 10.779 & 11.671 \\
\hline \multicolumn{14}{|l|}{$\begin{array}{l}\text { Relações } \\
\text { Interfinanceiras }\end{array}$} \\
\hline $\begin{array}{l}\text { Recebimentos e } \\
\text { Pagamentos à } \\
\text { Liquidar }\end{array}$ & 36 & 159 & - & - & - & - & - & - & - & - & - & - & - \\
\hline Correspondentes & 571 & 370 & 174 & 139 & 6 & 5 & 5 & 4 & 4 & 3 & 3 & 3 & 3 \\
\hline TOTAL & 607 & 529 & 174 & 139 & 6 & 5 & 5 & 4 & 4 & 3 & 3 & 3 & 3 \\
\hline \multicolumn{14}{|l|}{$\begin{array}{l}\text { Relações } \\
\text { Interdependências }\end{array}$} \\
\hline $\begin{array}{l}\text { Recursos em } \\
\text { Trânsito de } \\
\text { Terceiros }\end{array}$ & 1.338 & 1.782 & 1.746 & 1.901 & 2.226 & 2.497 & 2.771 & 3.048 & 3.353 & 3.631 & 3.932 & 4.257 & 4.610 \\
\hline $\begin{array}{l}\text { Transferência } \\
\text { Interna de } \\
\text { Recursos } \\
\end{array}$ & - & - & - & - & - & - & - & - & - & - & - & - & \\
\hline TOTAL & 1.338 & 1.782 & 1.746 & 1.901 & 2.226 & 2.497 & 2.771 & 3.048 & 3.353 & 3.631 & 3.932 & 4.257 & 4.610 \\
\hline \multicolumn{14}{|l|}{$\begin{array}{l}\text { Empréstimos e } \\
\text { Repasses }\end{array}$} \\
\hline Empréstimos & 9.391 & 7.223 & 7.561 & 7.135 & 5.778 & 6.481 & 7.193 & 7.913 & 8.704 & 9.425 & 10.205 & 11.050 & 11.965 \\
\hline Repasses & 7.048 & 7.571 & 8.398 & 9.428 & 11.641 & 12.438 & 13.290 & 14.201 & 15.174 & 16.213 & 17.324 & 18.510 & 19.778 \\
\hline TOTAL & 16.438 & 14.795 & 15.959 & 16.563 & 17.419 & 18.919 & 20.484 & 22.114 & 23.878 & 25.638 & 27.529 & 29.560 & 31.743 \\
\hline $\begin{array}{l}\text { Carteira de } \\
\text { Câmbio }\end{array}$ & 5.002 & 5.119 & 3.011 & 2.207 & 2.387 & 2.482 & 2.582 & 2.685 & 2.792 & 2.904 & 3.020 & 3.141 & 3.267 \\
\hline $\begin{array}{l}\text { Instrumentos } \\
\text { Financeiros } \\
\text { Derivativos }\end{array}$ & 577 & 52 & 174 & 238 & 519 & 582 & 646 & 711 & 782 & 847 & 917 & 993 & 1.075 \\
\hline $\begin{array}{l}\text { Provisões } \\
\text { Técnicas de } \\
\text { Seguro e } \\
\text { Capitalização }\end{array}$ & 19.155 & 26.409 & 33.669 & 40.863 & 49.129 & 55.103 & 61.164 & 67.281 & 74.009 & 80.137 & 86.772 & 93.957 & 101.737 \\
\hline $\begin{array}{l}\text { PASSIVOS QUE } \\
\text { GERAM } \\
\text { DESPESAS }\end{array}$ & 118.630 & 146.350 & 151.320 & 168.160 & 208.903 & 237.685 & 268.035 & 300.718 & 338.632 & 378.477 & 423.708 & 475.380 & 534.173 \\
\hline & & & & & & & & & & & & & \\
\hline \multicolumn{14}{|l|}{$\begin{array}{l}\text { Outras } \\
\text { Obrigações }\end{array}$} \\
\hline Cobrança e & 108 & 131 & 204 & 156 & 176 & 197 & 219 & 241 & 265 & 287 & 311 & 337 & 364 \\
\hline
\end{tabular}




\begin{tabular}{|c|c|c|c|c|c|c|c|c|c|c|c|c|c|}
\hline Discriminação & 2002 & 2003 & 2004 & 2005 & 2006 & 2007 & 2008 & 2009 & 2010 & 2011 & 2012 & 2013 & 2014 \\
\hline \multicolumn{14}{|l|}{$\begin{array}{l}\text { Arrecadação de } \\
\text { Tributos }\end{array}$} \\
\hline $\begin{array}{l}\text { Sociais e } \\
\text { Estatutárias }\end{array}$ & 666 & 852 & 900 & 1.255 & 191 & 214 & 238 & 262 & 288 & 312 & 337 & 365 & 396 \\
\hline $\begin{array}{l}\text { Fiscais e } \\
\text { Previdenciárias }\end{array}$ & 4.364 & 4.781 & 4.495 & 5.041 & 8.015 & 8.990 & 9.978 & 10.976 & 12.074 & 13.074 & 14.156 & 15.328 & 16.598 \\
\hline $\begin{array}{l}\text { Negociação e } \\
\text { Intermediação de } \\
\text { Valores }\end{array}$ & 109 & 596 & 312 & 894 & 422 & 473 & 525 & 578 & 636 & 688 & 745 & 807 & 874 \\
\hline $\begin{array}{l}\text { Fundos } \\
\text { Financeiros de } \\
\text { Desenvolvimento }\end{array}$ & - & 4.995 & - & - & 1 & 1 & 1 & 1 & 2 & 2 & 2 & 2 & 2 \\
\hline $\begin{array}{l}\text { Dívida } \\
\text { Subordinada }\end{array}$ & 3.322 & 4.701 & 5.973 & 6.719 & 11.949 & 13.402 & 14.876 & 16.364 & 18.000 & 19.491 & 21.104 & 22.852 & 24.744 \\
\hline $\begin{array}{l}\text { Instrumentos } \\
\text { Híbridos de } \\
\text { Capital }\end{array}$ & - & - & - & - & - & - & - & - & - & - & - & - & - \\
\hline Diversos & 4.440 & - & 6.391 & 6.939 & 11.016 & 12.356 & 13.715 & 15.086 & 16.595 & 17.969 & 19.457 & 21.068 & 22.812 \\
\hline TOTAL & 13.011 & 16.056 & 18.277 & 21.004 & 31.770 & 35.633 & 39.553 & 43.508 & 47.859 & 51.822 & 56.113 & 60.759 & 65.789 \\
\hline $\begin{array}{l}\text { PASSIVOS QUE } \\
\text { NÃO GERAM } \\
\text { DESPESAS }\end{array}$ & 13.011 & 16.056 & 18.277 & 21.004 & 31.770 & 35.633 & 39.553 & 43.508 & 47.859 & 51.822 & 56.113 & 60.759 & 65.789 \\
\hline $\begin{array}{l}\text { Resultado de } \\
\text { Exercícios } \\
\text { Futuros } \\
\end{array}$ & 16 & 32 & 45 & 52 & 181 & 203 & 225 & 248 & 273 & 295 & 320 & 346 & 375 \\
\hline Minoritários & 271 & 113 & 71 & 58 & 57 & 64 & 71 & 78 & 86 & 93 & 101 & 109 & 118 \\
\hline \multicolumn{14}{|l|}{$\begin{array}{l}\text { Patrimônio } \\
\text { Líquido }\end{array}$} \\
\hline Capital Social & 5.200 & 7.000 & 7.000 & 13.000 & 14.200 & 14.200 & 14.200 & 14.200 & 14.200 & 14.200 & 14.200 & 14.200 & 14.200 \\
\hline $\begin{array}{l}\text { Reservas de } \\
\text { Capital }\end{array}$ & 7 & 9 & 11 & 36 & 55 & 55 & 55 & 55 & 55 & 55 & 55 & 55 & 55 \\
\hline $\begin{array}{l}\text { Reservas de } \\
\text { Reavaliação } \\
\end{array}$ & - & - & - & - & - & - & - & - & - & - & - & - & - \\
\hline $\begin{array}{l}\text { Ajuste de } \\
\text { Avaliação } \\
\text { Patrimonial }\end{array}$ & 9 & 479 & 458 & 508 & 1.644 & 1.644 & 1.644 & 1.644 & 1.644 & 1.644 & 1.644 & 1.644 & 1.644 \\
\hline $\begin{array}{l}\text { Reservas de } \\
\text { Lucro }\end{array}$ & 5.715 & 6.067 & 7.746 & 5.895 & 8.787 & 8.103 & 17.370 & 27.142 & 37.717 & 50.145 & 63.825 & 78.322 & 93.544 \\
\hline
\end{tabular}




\begin{tabular}{|c|c|c|c|c|c|c|c|c|c|c|c|c|c|}
\hline Discriminação & 2002 & 2003 & 2004 & 2005 & 2006 & 2007 & 2008 & 2009 & 2010 & 2011 & 2012 & 2013 & 2014 \\
\hline $\begin{array}{l}\text { Ações em } \\
\text { Tesouraria }\end{array}$ & (86) & (7) & - & $(30)$ & $(50)$ & $(50)$ & $(50)$ & $(50)$ & $(50)$ & $(50)$ & $(50)$ & $(50)$ & $(50)$ \\
\hline $\begin{array}{l}\text { PATRIMÔNIO } \\
\text { LÍQUIDO }\end{array}$ & 10.846 & 13.547 & 15.215 & 19.409 & 24.636 & 23.952 & 33.219 & 42.991 & 53.566 & 65.994 & 79.674 & 94.171 & 109.393 \\
\hline PASSIVO E PL & 142.773 & 176.098 & 184.926 & 208.683 & 265.547 & 297.537 & 341.104 & 387.543 & 440.416 & 496.681 & 559.914 & 630.765 & 709.849 \\
\hline
\end{tabular}

Apêndice 9: Projeção das DRE para o ano de 2007

\begin{tabular}{|c|c|c|c|c|c|c|c|c|c|c|c|c|c|}
\hline Discriminação & 2002 & 2003 & 2004 & 2005 & 2006 & 2007 & 2008 & 2009 & 2010 & 2011 & 2012 & 2013 & 2014 \\
\hline $\begin{array}{l}\text { Receitas de } \\
\text { Intermediação } \\
\text { Financeira }\end{array}$ & 31.913 & 28.034 & 26.203 & 33.701 & 38.222 & 46.268 & 54.354 & 61.216 & 71.152 & 81.254 & 92.377 & 105.545 & 120.109 \\
\hline Margem & $27,62 \%$ & $19,20 \%$ & $16,68 \%$ & $18,66 \%$ & $16,56 \%$ & $17,30 \%$ & $17,51 \%$ & $17,12 \%$ & $17,31 \%$ & $17,31 \%$ & $17,25 \%$ & $17,29 \%$ & $17,28 \%$ \\
\hline $\begin{array}{l}\text { Despesas de } \\
\text { Intermediação } \\
\text { Financeira }\end{array}$ & $(23.260)$ & (17.202) & $(15.014)$ & (18.926) & $(22.240)$ & $(25.213)$ & $(29.045)$ & (32.166) & $(36.279)$ & $(40.681)$ & $(45.420)$ & (50.995) & (57.327) \\
\hline Margem & $-19,61 \%$ & $-11,75 \%$ & $-9,92 \%$ & $-11,26 \%$ & $-10,65 \%$ & $-10,61 \%$ & $-10,84 \%$ & $-10,70 \%$ & $-10,71 \%$ & $-10,75 \%$ & $-10,72 \%$ & $-10,73 \%$ & $-10,73 \%$ \\
\hline Margem & 8.654 & 10.832 & 11.189 & 14.775 & 15.982 & 21.055 & 25.309 & 29.049 & 34.873 & 40.572 & 46.957 & 54.550 & 62.782 \\
\hline $\begin{array}{l}\text { Outras } \\
\text { Despesas/Receitas } \\
\text { Operacionais }\end{array}$ & $(7.291)$ & $(7.279)$ & (7.071) & $(6.921)$ & $(9.606)$ & $(10.774)$ & (11.959) & $(13.155)$ & $(14.471)$ & $(15.669)$ & (16.967) & (18.371) & (19.893) \\
\hline $\begin{array}{l}\text { Resultado } \\
\text { Operacional }\end{array}$ & 1.363 & 3.553 & 4.118 & 7.854 & 6.376 & 10.281 & 13.350 & 15.894 & 20.402 & 24.903 & 29.991 & 36.178 & 42.889 \\
\hline $\begin{array}{l}\text { Resultado Não } \\
\text { Operacional }\end{array}$ & 186 & $(841)$ & (491) & (106) & (9) & (10) & (11) & $(12)$ & (14) & (15) & (16) & (17) & (19) \\
\hline $\begin{array}{l}\text { Resultado Ant. } \\
\text { Trib e Part }\end{array}$ & 1.549 & 2.712 & 3.627 & 7.747 & 6.367 & 10.271 & 13.339 & 15.882 & 20.389 & 24.889 & 29.975 & 36.161 & 42.871 \\
\hline $\begin{array}{l}\text { Provisão para IR e } \\
\text { Contribuição } \\
\text { Social }\end{array}$ & $(460)$ & $(397)$ & $(554)$ & $(2.224)$ & $(1.304)$ & $(3.081)$ & $(4.002)$ & $(4.764)$ & $(6.117)$ & $(7.467)$ & (8.992) & $(10.848)$ & $(12.861)$ \\
\hline Reversão de JSCP & 947 & & & & & & & & & & & & \\
\hline Participações & (13) & (9) & (12) & (9) & (9) & (9) & (9) & (9) & (9) & (9) & (9) & (9) & (9) \\
\hline
\end{tabular}




\begin{tabular}{|c|c|c|c|c|c|c|c|c|c|c|c|c|c|}
\hline Discriminação & 2002 & 2003 & 2004 & 2005 & 2006 & 2007 & 2008 & 2009 & 2010 & 2011 & 2012 & 2013 & 2014 \\
\hline Minoritárias & & & & & & & & & & & & & \\
\hline $\begin{array}{l}\text { Lucro/Prejuízo } \\
\text { Exercício }\end{array}$ & 2.023 & 2.306 & 3.060 & 5.514 & 5.054 & 7.180 & 9.328 & 11.108 & 14.263 & 17.413 & 20.973 & 25.304 & 30.001 \\
\hline
\end{tabular}

\section{Apêndice 10: Fluxo de dividendos projetado e valores presentes}

\begin{tabular}{|c|c|c|c|c|c|c|c|c|c|c|}
\hline Discriminação & 2006 & 2007 & 2008 & 2009 & 2010 & 2011 & 2012 & 2013 & 2014 & 2015 \\
\hline Payout & $45,00 \%$ & $45,00 \%$ & $45,00 \%$ & $45,00 \%$ & $45,00 \%$ & $45,00 \%$ & $45,00 \%$ & $45,00 \%$ & $45,00 \%$ & $70 \%$ \\
\hline Lucro Líquido & 5.054 & 7.180 & 9.328 & 11.108 & 14.263 & 17.413 & 20.973 & 25.304 & 30.001 & 30.001 \\
\hline Dividendos & 2.274 & 3.231 & 4.198 & 4.999 & 6.418 & 7.836 & 9.438 & 11.387 & 13.500 & 21.000 \\
\hline Qtd de Ações & 3070 & 3070 & 3070 & 3070 & 3070 & 3070 & 3070 & 3070 & 3070 & 3070 \\
\hline DPS & 0,74 & 1,05 & 1,37 & 1,63 & 2,09 & 2,55 & 3,07 & 3,71 & 4,40 & 6,84 \\
\hline DPS US\$ & 0,35 & 0,49 & 0,62 & 0,73 & 0,92 & 1,12 & 1,35 & 1,63 & 1,93 & 3,00 \\
\hline VPL DPS US\$ & & 0,44 & 0,49 & 0,52 & 0,59 & 0,64 & 0,69 & 0,74 & 0,79 & \\
\hline VPL DPS R\$ & & 0,94 & 1,06 & 1,11 & 1,25 & 1,37 & 1,47 & 1,59 & 1,68 & \\
\hline
\end{tabular}

\section{Apêndice 11: Projeção da Carteira de Crédito para o ano de 2008}

\begin{tabular}{|c|c|c|c|c|c|c|c|c|c|c|c|c|c|}
\hline Ano & 2003 & 2004 & 2005 & 2006 & 2007 & 2008 & 2009 & 2010 & 2011 & 2012 & 2013 & 2014 & 2015 \\
\hline Carteira & 48.815 & 59.017 & 77.990 & 93.484 & 129.702 & 153.245 & 184.614 & 222.700 & 257.887 & 301.909 & 350.366 & 401.786 & 459.398 \\
\hline YoY \% & $5,6 \%$ & $20,9 \%$ & $32,1 \%$ & $19,9 \%$ & $38,7 \%$ & $18,2 \%$ & $20,5 \%$ & $20,6 \%$ & $15,8 \%$ & $17,1 \%$ & $16,1 \%$ & $14,7 \%$ & $14,3 \%$ \\
\hline
\end{tabular}

\section{Apêndice 12: Projeção da Carteira de Depósitos para o ano de 2008}

\begin{tabular}{|c|c|c|c|c|c|c|c|c|c|c|c|c|c|}
\hline Discriminação & 2003 & 2004 & 2005 & 2006 & 2007 & 2008 & 2009 & 2010 & 2011 & 2012 & 2013 & 2014 & 2015 \\
\hline \multicolumn{14}{|l|}{ Depósitos } \\
\hline À Vista & 12.909 & 15.298 & 15.956 & 20.527 & 28.495 & 33.768 & 40.016 & 47.420 & 56.195 & 66.593 & 78.915 & 93.517 & 110.821 \\
\hline YoY \% & $-3,45 \%$ & $18,50 \%$ & $4,30 \%$ & $28,65 \%$ & $38,82 \%$ & $23,92 \%$ & $30,46 \%$ & $31,07 \%$ & $28,48 \%$ & $30,01 \%$ & $29,85 \%$ & $29,45 \%$ & $29,77 \%$ \\
\hline Poupança & 22.140 & 24.783 & 26.201 & 27.612 & 32.813 & 40.663 & 50.390 & 62.445 & 77.383 & 95.896 & 118.836 & 147.265 & 182.495 \\
\hline YoY \% & $6,80 \%$ & $11,94 \%$ & $5,73 \%$ & $5,38 \%$ & $18,84 \%$ & $23,92 \%$ & $23,92 \%$ & $23,92 \%$ & $23,92 \%$ & $23,92 \%$ & $23,92 \%$ & $23,92 \%$ & $23,92 \%$ \\
\hline Interfinanceiros & 31 & 19 & 146 & 290 & 373 & 491 & 647 & 851 & 1.121 & 1.476 & 1.943 & 2.559 & 3.369 \\
\hline YoY \% & $31,67 \%$ & $-37,90 \%$ & $647,17 \%$ & $99,05 \%$ & $28,62 \%$ & $147,57 \%$ & $169,83 \%$ & $209,71 \%$ & $125,72 \%$ & $130,84 \%$ & $150,46 \%$ & $151,02 \%$ & $147,41 \%$ \\
\hline Prazo & 22.943 & 28.459 & 32.837 & 34.925 & 35.717 & 38.575 & 40.714 & 42.860 & 45.549 & 48.143 & 50.910 & 53.916 & 57.034 \\
\hline YoY \% & $3,17 \%$ & $24,04 \%$ & $15,38 \%$ & $6,36 \%$ & $2,27 \%$ & $8,00 \%$ & $5,54 \%$ & $5,27 \%$ & $6,27 \%$ & $5,70 \%$ & $5,75 \%$ & $5,91 \%$ & $5,78 \%$ \\
\hline
\end{tabular}




\begin{tabular}{|c|c|c|c|c|c|c|c|c|c|c|c|c|c|}
\hline Discriminação & 2003 & 2004 & 2005 & 2006 & 2007 & 2008 & 2009 & 2010 & 2011 & 2012 & 2013 & 2014 & 2015 \\
\hline $\begin{array}{c}\text { Outros } \\
\text { Depósitos }\end{array}$ & - & 84 & 266 & 551 & 925 & 1.027 & 1.135 & 1.246 & 1.360 & 1.479 & 1.609 & 1.750 & 1.903 \\
\hline TOTAL & & & & & & & & & & & & & \\
\hline YoY \% & & & & & & & & & & & & & \\
\hline
\end{tabular}

\section{Apêndice 13: Projeção dos Balanços Patrimoniais para o ano de 2008}

\begin{tabular}{|c|c|c|c|c|c|c|c|c|c|c|c|c|c|}
\hline Discriminação & 2003 & 2004 & 2005 & 2006 & 2007 & 2008 & 2009 & 2010 & 2011 & 2012 & 2013 & 2014 & 2015 \\
\hline \multicolumn{14}{|l|}{ ATIVO } \\
\hline & & & & & & & & & & & & & \\
\hline Disponibilidades & 2.448 & 2.639 & 3.363 & 4.762 & 5.487 & 6.094 & 6.734 & 7.388 & 8.066 & 8.773 & 9.542 & 10.379 & 11.290 \\
\hline TOTAL & 2.448 & 2.639 & 3.363 & 4.762 & 5.487 & 6.094 & 6.734 & 7.388 & 8.066 & 8.773 & 9.542 & 10.379 & 11.290 \\
\hline \multicolumn{14}{|l|}{$\begin{array}{l}\text { Aplicações } \\
\text { Interfinanceiras }\end{array}$} \\
\hline $\begin{array}{l}\text { Aplicações no } \\
\text { Mercado Aberto }\end{array}$ & 26.754 & 15.667 & 19.616 & 20.617 & 32.015 & 35.559 & 39.293 & 43.108 & 47.061 & 51.188 & 55.678 & 60.561 & 65.872 \\
\hline $\begin{array}{l}\text { Aplicações em } \\
\text { depósitos } \\
\text { interfinanceiros }\end{array}$ & 4.970 & 6.683 & 5.391 & 5.373 & 5.617 & 6.239 & 6.894 & 7.563 & 8.257 & 8.981 & 9.769 & 10.625 & 11.557 \\
\hline $\begin{array}{l}\text { Provisão para } \\
\text { perdas }\end{array}$ & - & (3) & (0) & (1) & (10) & $(11)$ & $(12)$ & $(13)$ & (15) & $(16)$ & $(17)$ & (19) & $(21)$ \\
\hline TOTAL & 31.724 & 22.347 & 25.006 & 25.989 & 37.622 & 41.787 & 46.174 & 50.658 & 55.303 & 60.153 & 65.429 & 71.167 & 77.408 \\
\hline $\begin{array}{l}\text { Títulos e Valores } \\
\text { Mobiliários }\end{array}$ & 53.572 & 62.024 & 63.976 & 96.701 & 113.245 & 125.781 & 138.988 & 152.484 & 166.467 & 181.066 & 196.945 & 214.218 & 233.004 \\
\hline $\begin{array}{l}\text { Instrumentos } \\
\text { Financeiros } \\
\text { Derivativos }\end{array}$ & 232 & 398 & 474 & 549 & 1.207 & 1.341 & 1.481 & 1.625 & 1.774 & 1.930 & 2.099 & 2.283 & 2.483 \\
\hline TOTAL & 53.805 & 62.422 & 64.451 & 97.250 & 114.452 & 127.122 & 140.470 & 154.109 & 168.241 & 182.996 & 199.045 & 216.501 & 235.488 \\
\hline \multicolumn{14}{|l|}{$\begin{array}{l}\text { Relações } \\
\text { Interfinanceiras }\end{array}$} \\
\hline $\begin{array}{l}\text { Pagamentos e } \\
\text { Recebimentos a } \\
\text { Liquidar }\end{array}$ & 20 & 22 & 39 & 51 & 37 & 41 & 45 & 50 & 54 & 59 & 64 & 70 & 76 \\
\hline $\begin{array}{l}\text { Depósitos no } \\
\text { BACEN }\end{array}$ & 13.580 & 15.696 & 16.445 & 18.665 & 23.539 & 24.481 & 25.460 & 26.478 & 27.537 & 28.639 & 29.784 & 30.976 & 32.215 \\
\hline $\begin{array}{l}\text { SFH - Sistema } \\
\text { Financeiro de } \\
\text { Habitacional }\end{array}$ & 392 & 335 & 396 & 406 & 453 & 503 & 556 & 610 & 666 & 724 & 788 & 857 & 932 \\
\hline Correspondentes & 20 & 34 & 42 & 3 & 8 & 9 & 10 & 11 & 12 & 13 & 14 & 15 & 16 \\
\hline
\end{tabular}




\begin{tabular}{|c|c|c|c|c|c|c|c|c|c|c|c|c|c|}
\hline Discriminação & 2003 & 2004 & 2005 & 2006 & 2007 & 2008 & 2009 & 2010 & 2011 & 2012 & 2013 & 2014 & 2015 \\
\hline \multicolumn{14}{|l|}{$\begin{array}{l}\text { e Repasses } \\
\text { Interfinanceiros }\end{array}$} \\
\hline TOTAL & 14.013 & 16.087 & 16.922 & 19.125 & 24.037 & 25.034 & 26.071 & 27.149 & 28.269 & 29.435 & 30.650 & 31.918 & 33.239 \\
\hline \multicolumn{14}{|l|}{$\begin{array}{l}\text { Relações } \\
\text { Interdependências }\end{array}$} \\
\hline $\begin{array}{l}\text { Relações } \\
\text { Interdependências }\end{array}$ & 515 & 148 & 173 & 186 & 429 & 476 & 527 & 578 & 631 & 686 & 746 & 812 & 883 \\
\hline TOTAL & 515 & 148 & 173 & 186 & 429 & 476 & 527 & 578 & 631 & 686 & 746 & 812 & 883 \\
\hline \multicolumn{14}{|l|}{$\begin{array}{l}\text { Carteira de } \\
\text { Crédito }\end{array}$} \\
\hline $\begin{array}{l}\text { Carteira de } \\
\text { Crédito }\end{array}$ & 48.815 & 59.017 & 77.990 & 93.484 & 129.702 & 153.245 & 184.614 & 222.700 & 257.887 & 301.909 & 350.366 & 401.786 & 459.398 \\
\hline Provisões & $(5.346)$ & $(5.569)$ & $(7.250)$ & $(10.017)$ & $(13.444)$ & $(15.884)$ & $(19.136)$ & $(23.084)$ & $(26.731)$ & $(31.294)$ & $(36.316)$ & $(41.646)$ & $(47.618)$ \\
\hline TOTAL & 43.469 & 53.447 & 70.740 & 83.467 & 116.258 & 137.361 & 165.478 & 199.616 & 231.156 & 270.615 & 314.049 & 360.140 & 411.780 \\
\hline $\begin{array}{l}\text { Carteira de } \\
\text { Câmbio }\end{array}$ & 11.103 & 7.337 & 6.937 & 7.946 & 9.837 & 10.230 & 10.640 & 11.065 & 11.508 & 11.968 & 12.447 & 12.945 & 13.463 \\
\hline $\begin{array}{l}\text { Créditos } \\
\text { Específicos }\end{array}$ & - & - & - & - & - & - & - & - & - & - & - & - & - \\
\hline $\begin{array}{l}\text { ATIVOS QUE } \\
\text { GERAM } \\
\text { RECEITA }\end{array}$ & 157.077 & 164.426 & 187.592 & 238.725 & 308.122 & 348.104 & 396.093 & 450.563 & 503.174 & 564.626 & 631.908 & 703.861 & 783.550 \\
\hline & & & & & & & & & & & & & \\
\hline \multicolumn{14}{|l|}{ Outros Créditos } \\
\hline $\begin{array}{l}\text { Avais e Fianças } \\
\text { Honrados }\end{array}$ & 1 & 1 & - & - & 12 & 13 & 15 & 16 & 18 & 19 & 21 & 23 & 25 \\
\hline $\begin{array}{l}\text { Rendas a } \\
\text { Receber }\end{array}$ & 331 & 197 & 183 & 176 & 371 & 412 & 455 & 500 & 545 & 593 & 645 & 702 & 763 \\
\hline $\begin{array}{l}\text { Prêmios de } \\
\text { Seguro a Receber }\end{array}$ & 889 & 988 & 1.073 & 1.257 & 1.276 & 1.417 & 1.566 & 1.718 & 1.876 & 2.040 & 2.219 & 2.414 & 2.625 \\
\hline $\begin{array}{l}\text { Negociação e } \\
\text { Intermediação de } \\
\text { Valores }\end{array}$ & 603 & 357 & 1.124 & 709 & 1.378 & 1.531 & 1.691 & 1.855 & 2.026 & 2.203 & 2.396 & 2.607 & 2.835 \\
\hline Diversos & 11.173 & 12.785 & 12.789 & 19.214 & 22.955 & 25.496 & 28.173 & 30.909 & 33.743 & 36.702 & 39.921 & 43.422 & 47.230 \\
\hline TOTAL & 12.996 & 14.328 & 15.169 & 21.356 & 25.992 & 28.869 & 31.901 & 34.998 & 38.207 & 41.558 & 45.203 & 49.167 & 53.479 \\
\hline \multicolumn{14}{|l|}{$\begin{array}{l}\text { Outros Valores a } \\
\text { Receber }\end{array}$} \\
\hline $\begin{array}{l}\text { Despesas } \\
\text { Antecipadas }\end{array}$ & 739 & 1.037 & 1.377 & 1.794 & 1.896 & 1.972 & 2.051 & 2.133 & 2.218 & 2.307 & 2.399 & 2.495 & 2.595 \\
\hline $\begin{array}{l}\text { Outros Valores e } \\
\text { Bens }\end{array}$ & 587 & 477 & 368 & 369 & 390 & 406 & 422 & 439 & 456 & 474 & 493 & 513 & 534 \\
\hline
\end{tabular}




\begin{tabular}{|c|c|c|c|c|c|c|c|c|c|c|c|c|c|}
\hline Discriminação & 2003 & 2004 & 2005 & 2006 & 2007 & 2008 & 2009 & 2010 & 2011 & 2012 & 2013 & 2014 & 2015 \\
\hline $\begin{array}{l}\text { Provisões para } \\
\text { Desvalorizações }\end{array}$ & $(257)$ & $(230)$ & $(181)$ & (189) & (179) & (199) & $(220)$ & (241) & $(263)$ & $(286)$ & (311) & (339) & $(368)$ \\
\hline TOTAL & 1.069 & 1.284 & 1.564 & 1.974 & 2.107 & 2.179 & 2.253 & 2.330 & 2.411 & 2.495 & 2.581 & 2.670 & 2.760 \\
\hline $\begin{array}{l}\text { ATIVOS QUE } \\
\text { NÃO GERAM } \\
\text { RECEITA }\end{array}$ & 14.065 & 15.612 & 16.733 & 23.330 & 28.099 & 31.048 & 34.153 & 37.329 & 40.619 & 44.053 & 47.784 & 51.837 & 56.239 \\
\hline & & & & & & & & & & & & & \\
\hline \multicolumn{14}{|l|}{ Investimentos } \\
\hline $\begin{array}{l}\text { Participações em } \\
\text { Controladas }\end{array}$ & 370 & 496 & 439 & 403 & 468 & 520 & 574 & 630 & 688 & 748 & 814 & 885 & 963 \\
\hline $\begin{array}{l}\text { Outros } \\
\text { Investimentos }\end{array}$ & 858 & 971 & 896 & 652 & 487 & 506 & 527 & 548 & 570 & 593 & 616 & 641 & 666 \\
\hline $\begin{array}{l}\text { Provisão para } \\
\text { perdas de } \\
\text { investimentos }\end{array}$ & $(366)$ & $(366)$ & $(350)$ & $(358)$ & $(351)$ & $(365)$ & $(380)$ & $(395)$ & $(411)$ & $(427)$ & $(444)$ & $(462)$ & $(480)$ \\
\hline TOTAL & 862 & 1.101 & 985 & 697 & 604 & 661 & 721 & 783 & 847 & 914 & 986 & 1.064 & 1.149 \\
\hline \multicolumn{14}{|l|}{ Imobilizado } \\
\hline $\begin{array}{l}\text { Imóveis em uso + } \\
\text { Bens Arrendados }\end{array}$ & 1.399 & 1.357 & 1.116 & 1.055 & 1.076 & 1.119 & 1.164 & 1.210 & 1.259 & 1.309 & 1.361 & 1.416 & 1.473 \\
\hline $\begin{array}{l}\text { Outras } \\
\text { Imobilizações de } \\
\text { uso }\end{array}$ & 3.544 & 3.663 & 3.668 & 4.127 & 3.866 & 4.021 & 4.181 & 4.349 & 4.523 & 4.704 & 4.892 & 5.087 & 5.291 \\
\hline $\begin{array}{l}\text { Depreciação } \\
\text { Acumulada }\end{array}$ & $(2.617)$ & $(2.731)$ & $(2.789)$ & $(3.030)$ & $(2.839)$ & $(2.953)$ & $(3.071)$ & (3.193) & $(3.321)$ & $(3.454)$ & $(3.592)$ & $(3.736)$ & (3.885) \\
\hline TOTAL & 2.326 & 2.289 & 1.995 & 2.152 & 2.103 & 2.187 & 2.275 & 2.366 & 2.460 & 2.559 & 2.661 & 2.767 & 2.878 \\
\hline \multicolumn{14}{|l|}{ Intangível } \\
\hline Diferido & 1.768 & 1.497 & 1.378 & 643 & - & - & - & - & - & - & - & - & - \\
\hline \multicolumn{14}{|l|}{$\begin{array}{l}\text { Outros Ativos } \\
\text { Intangíveis }\end{array}$} \\
\hline \multicolumn{14}{|l|}{$\begin{array}{l}\text { (Amortização } \\
\text { Acumulada) }\end{array}$} \\
\hline TOTAL & 1.768 & 1.497 & 1.378 & 643 & - & - & - & - & - & - & - & - & - \\
\hline PERMANENTE & 4.956 & 4.888 & 4.358 & 3.492 & 2.707 & 2.848 & 2.996 & 3.149 & 3.307 & 3.472 & 3.647 & 3.832 & 4.027 \\
\hline TOTAL ATIVOS & 176.098 & 184.926 & 208.683 & 265.547 & 338.928 & 382.001 & 433.243 & 491.041 & 547.100 & 612.152 & 683.339 & 759.529 & 843.817 \\
\hline & & & & & & & & & & & & & \\
\hline \multicolumn{14}{|l|}{ PASSIVO } \\
\hline & & & & & & & & & & & & & \\
\hline Depósitos & & & & & & & & & & & & & \\
\hline
\end{tabular}




\begin{tabular}{|c|c|c|c|c|c|c|c|c|c|c|c|c|c|}
\hline Discriminação & 2003 & 2004 & 2005 & 2006 & 2007 & 2008 & 2009 & 2010 & 2011 & 2012 & 2013 & 2014 & 2015 \\
\hline À Vista & 12.909 & 15.298 & 15.956 & 20.527 & 28.495 & 33.768 & 40.016 & 47.420 & 56.195 & 66.593 & 78.915 & 93.517 & 110.821 \\
\hline Poupança & 22.140 & 24.783 & 26.201 & 27.612 & 32.813 & 40.663 & 50.390 & 62.445 & 77.383 & 95.896 & 118.836 & 147.265 & 182.495 \\
\hline Interfinanceiros & 31 & 19 & 146 & 290 & 373 & 491 & 647 & 851 & 1.121 & 1.476 & 1.943 & 2.559 & 3.369 \\
\hline Prazo & 22.943 & 28.459 & 32.837 & 34.925 & 35.717 & 38.575 & 40.714 & 42.860 & 45.549 & 48.143 & 50.910 & 53.916 & 57.034 \\
\hline Outros & - & 84 & 266 & 551 & 925 & 1.027 & 1.135 & 1.246 & 1.360 & 1.479 & 1.609 & 1.750 & 1.903 \\
\hline TOTAL & 58.024 & 68.643 & 75.406 & 83.905 & 98.323 & 114.524 & 132.902 & 154.822 & 181.607 & 213.586 & 252.213 & 299.006 & 355.621 \\
\hline \multicolumn{14}{|l|}{$\begin{array}{l}\text { Captação } \\
\text { Mercado Aberto }\end{array}$} \\
\hline $\begin{array}{l}\text { Própria + Livre de } \\
\text { Movimentação }\end{array}$ & 15.234 & 8.456 & 12.691 & 44.204 & 44.056 & 48.933 & 54.071 & 59.321 & 64.761 & 70.441 & 76.618 & 83.338 & 90.646 \\
\hline de Terceiros & 17.559 & 14.431 & 11.948 & 3.472 & 29.578 & 32.852 & 36.302 & 39.827 & 43.479 & 47.292 & 51.439 & 55.951 & 60.857 \\
\hline TOTAL & 32.793 & 22.886 & 24.639 & 47.676 & 73.634 & 81.785 & 90.373 & 99.148 & 108.240 & 117.732 & 128.058 & 139.288 & 151.504 \\
\hline \multicolumn{14}{|l|}{$\begin{array}{l}\text { Recursos de } \\
\text { Aceite e Emissão } \\
\text { de Títulos }\end{array}$} \\
\hline $\begin{array}{l}\text { Recursos de } \\
\text { Debêntures + } \\
\text { Imobiliários }\end{array}$ & 1.038 & 681 & 3.472 & 3.461 & 3.497 & 3.884 & 4.292 & 4.709 & 5.140 & 5.591 & 6.082 & 6.615 & 7.195 \\
\hline $\begin{array}{l}\text { Títulos e Valores } \\
\text { Mobiliários no } \\
\text { Exterior }\end{array}$ & 5.809 & 4.376 & 2.731 & 2.175 & 2.991 & 3.322 & 3.671 & 4.027 & 4.397 & 4.782 & 5.202 & 5.658 & 6.154 \\
\hline TOTAL & 6.847 & 5.057 & 6.204 & 5.636 & 6.488 & 7.206 & 7.963 & 8.736 & 9.537 & 10.374 & 11.283 & 12.273 & 13.349 \\
\hline \multicolumn{14}{|l|}{$\begin{array}{l}\text { Relações } \\
\text { Interfinanceiras }\end{array}$} \\
\hline $\begin{array}{l}\text { Recebimentos e } \\
\text { Pagamentos à } \\
\text { Liquidar }\end{array}$ & 159 & - & - & - & - & - & - & - & - & - & - & - & - \\
\hline Correspondentes & 370 & 174 & 139 & 6 & 17 & 15 & 14 & 12 & 11 & 10 & 9 & 8 & 8 \\
\hline TOTAL & 529 & 174 & 139 & 6 & 17 & 15 & 14 & 12 & 11 & 10 & 9 & 8 & 8 \\
\hline \multicolumn{14}{|l|}{$\begin{array}{l}\text { Relações } \\
\text { Interdependências }\end{array}$} \\
\hline $\begin{array}{l}\text { Recursos em } \\
\text { Trânsito de } \\
\text { Terceiros }\end{array}$ & 1.782 & 1.746 & 1.901 & 2.226 & 2.521 & 2.800 & 3.094 & 3.395 & 3.706 & 4.031 & 4.384 & 4.769 & 5.187 \\
\hline $\begin{array}{l}\text { Transferência } \\
\text { Interna de } \\
\text { Recursos }\end{array}$ & - & - & - & - & - & - & - & - & - & - & - & & \\
\hline TOTAL & 1.782 & 1.746 & 1.901 & 2.226 & 2.521 & 2.800 & 3.094 & 3.395 & 3.706 & 4.031 & 4.384 & 4.769 & 5.187 \\
\hline \multicolumn{14}{|l|}{$\begin{array}{l}\text { Empréstimos e } \\
\text { Repasses }\end{array}$} \\
\hline Empréstimos & 7.223 & 7.561 & 7.135 & 5.778 & 8.066 & 8.959 & 9.900 & 10.861 & 11.857 & 12.897 & 14.028 & 15.258 & 16.596 \\
\hline
\end{tabular}




\begin{tabular}{|c|c|c|c|c|c|c|c|c|c|c|c|c|c|}
\hline Discriminação & 2003 & 2004 & 2005 & 2006 & 2007 & 2008 & 2009 & 2010 & 2011 & 2012 & 2013 & 2014 & 2015 \\
\hline Repasses & 7.571 & 8.398 & 9.428 & 11.641 & 15.344 & 16.303 & 17.322 & 18.405 & 19.555 & 20.777 & 22.076 & 23.455 & 24.921 \\
\hline TOTAL & 14.795 & 15.959 & 16.563 & 17.419 & 23.410 & 25.262 & 27.222 & 29.265 & 31.412 & 33.674 & 36.103 & 38.713 & 41.517 \\
\hline $\begin{array}{l}\text { Carteira de } \\
\text { Câmbio }\end{array}$ & 5.119 & 3.011 & 2.207 & 2.387 & 3.467 & 3.606 & 3.750 & 3.900 & 4.056 & 4.218 & 4.387 & 4.562 & 4.745 \\
\hline $\begin{array}{l}\text { Instrumentos } \\
\text { Financeiros } \\
\text { Derivativos }\end{array}$ & 52 & 174 & 238 & 519 & 952 & 1.057 & 1.168 & 1.282 & 1.399 & 1.522 & 1.656 & 1.801 & 1.959 \\
\hline $\begin{array}{l}\text { Provisões } \\
\text { Técnicas de } \\
\text { Seguro e } \\
\text { Capitalização }\end{array}$ & 26.409 & 33.669 & 40.863 & 49.129 & 58.526 & 65.005 & 71.830 & 78.805 & 86.031 & 93.576 & 101.783 & 110.709 & 120.419 \\
\hline & & & & & & & & & & & & & \\
\hline $\begin{array}{l}\text { PASSIVOS QUE } \\
\text { GERAM } \\
\text { DESPESAS }\end{array}$ & 146.350 & 151.320 & 168.160 & 208.903 & 267.338 & 301.261 & 338.315 & 379.365 & 426.000 & 478.724 & 539.876 & 611.130 & 694.309 \\
\hline & & & & & & & & & & & & & \\
\hline \multicolumn{14}{|l|}{$\begin{array}{l}\text { Outras } \\
\text { Obrigações }\end{array}$} \\
\hline $\begin{array}{l}\text { Cobrança e } \\
\text { Arrecadação de } \\
\text { Tributos }\end{array}$ & 131 & 204 & 156 & 176 & 229 & 254 & 281 & 308 & 337 & 366 & 398 & 433 & 471 \\
\hline $\begin{array}{l}\text { Sociais e } \\
\text { Estatutárias }\end{array}$ & 852 & 900 & 1.255 & 191 & 2.195 & 2.438 & 2.694 & 2.956 & 3.227 & 3.510 & 3.817 & 4.152 & 4.516 \\
\hline $\begin{array}{l}\text { Fiscais e } \\
\text { Previdenciárias }\end{array}$ & 4.781 & 4.495 & 5.041 & 8.015 & 9.840 & 10.929 & 12.077 & 13.250 & 14.465 & 15.733 & 17.113 & 18.614 & 20.246 \\
\hline $\begin{array}{l}\text { Negociação e } \\
\text { Intermediação de } \\
\text { Valores }\end{array}$ & 596 & 312 & 894 & 422 & 658 & 731 & 808 & 886 & 967 & 1.052 & 1.144 & 1.245 & 1.354 \\
\hline $\begin{array}{l}\text { Fundos } \\
\text { Financeiros de } \\
\text { Desenvolvimento }\end{array}$ & 4.995 & - & - & 1 & 2 & 2 & 2 & 3 & 3 & 3 & 3 & 4 & 4 \\
\hline $\begin{array}{l}\text { Dívida } \\
\text { Subordinada }\end{array}$ & 4.701 & 5.973 & 6.719 & 11.949 & 15.818 & 17.569 & 19.414 & 21.299 & 23.252 & 25.291 & 27.509 & 29.922 & 32.546 \\
\hline $\begin{array}{l}\text { Instrumentos } \\
\text { Híbridos de } \\
\text { Capital }\end{array}$ & - & - & - & - & - & - & - & - & - & - & - & - & - \\
\hline Diversos & - & 6.391 & 6.939 & 11.016 & 14.362 & 15.952 & 17.627 & 19.338 & 21.112 & 22.963 & 24.977 & 27.168 & 29.550 \\
\hline TOTAL & 16.056 & 18.277 & 21.004 & 31.770 & 43.104 & 47.876 & 52.903 & 58.039 & 63.362 & 68.918 & 74.963 & 81.537 & 88.688 \\
\hline $\begin{array}{l}\text { PASSIVOS QUE } \\
\text { NÃO GERAM }\end{array}$ & 16.056 & 18.277 & 21.004 & 31.770 & 43.104 & 47.876 & 52.903 & 58.039 & 63.362 & 68.918 & 74.963 & 81.537 & 88.688 \\
\hline
\end{tabular}




\begin{tabular}{|c|c|c|c|c|c|c|c|c|c|c|c|c|c|}
\hline Discriminação & 2003 & 2004 & 2005 & 2006 & 2007 & 2008 & 2009 & 2010 & 2011 & 2012 & 2013 & 2014 & 2015 \\
\hline \multicolumn{14}{|l|}{ DESPESAS } \\
\hline & & & & & & & & & & & & & \\
\hline $\begin{array}{l}\text { Resultado de } \\
\text { Exercícios } \\
\text { Futuros }\end{array}$ & 32 & 45 & 52 & 181 & 189 & 210 & 232 & 254 & 278 & 302 & 329 & 358 & 389 \\
\hline Minoritários & 113 & 71 & 58 & 57 & 155 & 172 & 190 & 209 & 228 & 248 & 270 & 293 & 319 \\
\hline \multicolumn{14}{|l|}{$\begin{array}{l}\text { Patrimônio } \\
\text { Líquido }\end{array}$} \\
\hline Capital Social & 7.000 & 7.000 & 13.000 & 14.200 & 16.785 & 16.785 & 16.785 & 16.785 & 16.785 & 16.785 & 16.785 & 16.785 & 16.785 \\
\hline $\begin{array}{l}\text { Reservas de } \\
\text { Capital }\end{array}$ & 9 & 11 & 36 & 55 & 56 & 56 & 56 & 56 & 56 & 56 & 56 & 56 & 56 \\
\hline $\begin{array}{l}\text { Reservas de } \\
\text { Reavaliação }\end{array}$ & - & - & - & - & - & - & - & - & - & - & - & - & - \\
\hline $\begin{array}{l}\text { Ajuste de } \\
\text { Avaliação } \\
\text { Patrimonial }\end{array}$ & 479 & 458 & 508 & 1.644 & 1.470 & 1.470 & 1.470 & 1.470 & 1.470 & 1.470 & 1.470 & 1.470 & 1.470 \\
\hline $\begin{array}{l}\text { Reservas de } \\
\text { Lucro }\end{array}$ & 6.067 & 7.746 & 5.895 & 8.787 & 9.963 & 14.303 & 23.424 & 34.994 & 39.054 & 45.781 & 49.724 & 48.032 & 41.934 \\
\hline $\begin{array}{l}\text { Ações em } \\
\text { Tesouraria }\end{array}$ & (7) & - & (30) & (50) & $(132)$ & $(132)$ & $(132)$ & $(132)$ & $(132)$ & $(132)$ & $(132)$ & $(132)$ & $(132)$ \\
\hline $\begin{array}{l}\text { PATRIMÔNIO } \\
\text { LíQUIDO } \\
\end{array}$ & 13.547 & 15.215 & 19.409 & 24.636 & 28.142 & 32.482 & 41.603 & 53.173 & 57.233 & 63.960 & 67.903 & 66.211 & 60.113 \\
\hline PASSIVO E PL & 176.098 & 184.926 & 208.683 & 265.547 & 338.928 & 382.001 & 433.243 & 491.041 & 547.100 & 612.152 & 683.339 & 759.529 & 843.817 \\
\hline
\end{tabular}

Apêndice 14: Projeção das DRE para o ano de 2008

\begin{tabular}{|c|c|c|c|c|c|c|c|c|c|c|c|c|c|}
\hline Discriminação & 2003 & 2004 & 2005 & 2006 & 2007 & 2008 & 2009 & 2010 & 2011 & 2012 & 2013 & 2014 & 2015 \\
\hline $\begin{array}{l}\text { Receitas de } \\
\text { Intermediação } \\
\text { Financeira }\end{array}$ & 28.034 & 26.203 & 33.701 & 38.222 & 41.605 & 55.372 & 60.257 & 67.344 & 77.592 & 86.099 & 96.395 & 108.063 & 120.084 \\
\hline Margem & $19,20 \%$ & $16,68 \%$ & $18,66 \%$ & $16,56 \%$ & $13,95 \%$ & $16,39 \%$ & $15,63 \%$ & $15,32 \%$ & $15,78 \%$ & $15,58 \%$ & $15,56 \%$ & $15,64 \%$ & $15,59 \%$ \\
\hline $\begin{array}{l}\text { Despesas de } \\
\text { Intermediação } \\
\text { Financeira }\end{array}$ & $(17.202)$ & $(15.014)$ & $(18.926)$ & $(22.240)$ & $(23.572)$ & $(30.847)$ & $(33.496)$ & $(36.619)$ & $(42.306)$ & $(47.050)$ & $(52.929)$ & $(60.223)$ & $(68.242)$ \\
\hline Margem & $-11,75 \%$ & $-9,92 \%$ & $-11,26 \%$ & $-10,65 \%$ & $-8,82 \%$ & $-10,24 \%$ & $-9,90 \%$ & $-9,65 \%$ & $-9,93 \%$ & $-9,83 \%$ & $-9,80 \%$ & $-9,85 \%$ & $-9,83 \%$ \\
\hline Margem & 10.832 & 11.189 & 14.775 & 15.982 & 18.032 & 24.524 & 26.761 & 30.726 & 35.286 & 39.049 & 43.466 & 47.840 & 51.842 \\
\hline Outras & (7.279) & $(7.071)$ & $(6.921)$ & $(9.606)$ & $(8.691)$ & $(9.653)$ & $(10.666)$ & $(11.702)$ & $(12.775)$ & $(13.896)$ & $(15.114)$ & $(16.440)$ & (17.882) \\
\hline
\end{tabular}




\begin{tabular}{|c|c|c|c|c|c|c|c|c|c|c|c|c|c|}
\hline Discriminação & 2003 & 2004 & 2005 & 2006 & 2007 & 2008 & 2009 & 2010 & 2011 & 2012 & 2013 & 2014 & 2015 \\
\hline \multicolumn{14}{|l|}{$\begin{array}{l}\text { Despesas/Receitas } \\
\text { Operacionais }\end{array}$} \\
\hline $\begin{array}{l}\text { Resultado } \\
\text { Operacional }\end{array}$ & 3.553 & 4.118 & 7.854 & 6.376 & 9.341 & 14.871 & 16.094 & 19.023 & 22.510 & 25.153 & 28.352 & 31.400 & 33.960 \\
\hline $\begin{array}{l}\text { Resultado Não } \\
\text { Operacional }\end{array}$ & $(841)$ & (491) & $(106)$ & (9) & 1.203 & 1.336 & 1.476 & 1.620 & 1.768 & 1.923 & 2.092 & 2.275 & 2.475 \\
\hline $\begin{array}{l}\text { Resultado Ant. } \\
\text { Trib e Part }\end{array}$ & 2.712 & 3.627 & 7.747 & 6.367 & 10.544 & 16.207 & 17.570 & 20.643 & 24.278 & 27.077 & 30.444 & 33.675 & 36.435 \\
\hline $\begin{array}{l}\text { Provisão para IR e } \\
\text { Contribuição } \\
\text { Social }\end{array}$ & $(397)$ & $(554)$ & (2.224) & $(1.304)$ & $(2.523)$ & $(4.862)$ & $(5.271)$ & $(6.193)$ & $(7.284)$ & $(8.123)$ & $(9.133)$ & (10.103) & $(10.930)$ \\
\hline \multirow{2}{*}{\multicolumn{14}{|c|}{ Reversão de JSCP }} \\
\hline & & & & & & & & & & & & & \\
\hline $\begin{array}{l}\text { Participações } \\
\text { Minoritárias } \\
\end{array}$ & (9) & $(12)$ & (9) & (9) & (9) & (9) & (9) & (9) & (9) & (9) & (9) & (9) & (9) \\
\hline $\begin{array}{l}\text { Lucro/Prejuízo } \\
\text { Exercício }\end{array}$ & 2.306 & 3.060 & 5.514 & 5.054 & 8.012 & 11.336 & 12.290 & 14.441 & 16.986 & 18.945 & 21.302 & 23.564 & 25.495 \\
\hline
\end{tabular}

\section{Apêndice 15: Fluxo de dividendos projetado e valores presentes}

\begin{tabular}{|c|c|c|c|c|c|c|c|c|c|c|}
\hline Discriminação & 2007 & 2008 & 2009 & 2010 & 2011 & 2012 & 2013 & 2014 & 2015 & 2016 \\
\hline Payout & $37,10 \%$ & $37,10 \%$ & $37,10 \%$ & $37,10 \%$ & $37,10 \%$ & $37,10 \%$ & $37,10 \%$ & $37,10 \%$ & $37,10 \%$ & $70 \%$ \\
\hline Lucro Líquido & 8.012 & 11.336 & 12.290 & 14.441 & 16.986 & 18.945 & 21.302 & 23.564 & 25.495 & 25.495 \\
\hline Dividendos & 2.972 & 4.206 & 4.560 & 5.358 & 6.302 & 7.028 & 7.903 & 8.742 & 9.459 & 17.847 \\
\hline Qtd de Ações & 3070 & 3070 & 3070 & 3070 & 3070 & 3070 & 3070 & 3070 & 3070 & 3070 \\
\hline DPS & 0,97 & 1,37 & 1,49 & 1,75 & 2,05 & 2,29 & 2,57 & 2,85 & 3,08 & 5,81 \\
\hline DPS US\$ & 0,55 & 0,81 & 0,85 & 0,95 & 1,07 & 1,20 & 1,35 & 1,49 & 1,61 & 3,04 \\
\hline VPL DPS US\$ & & 0,72 & 0,68 & 0,68 & 0,69 & 0,69 & 0,69 & 0,69 & 0,66 & \\
\hline VPL DPS R\$ & & 1,28 & 1,20 & 1,21 & 1,22 & 1,22 & 1,23 & 1,22 & 1,18 & \\
\hline
\end{tabular}


